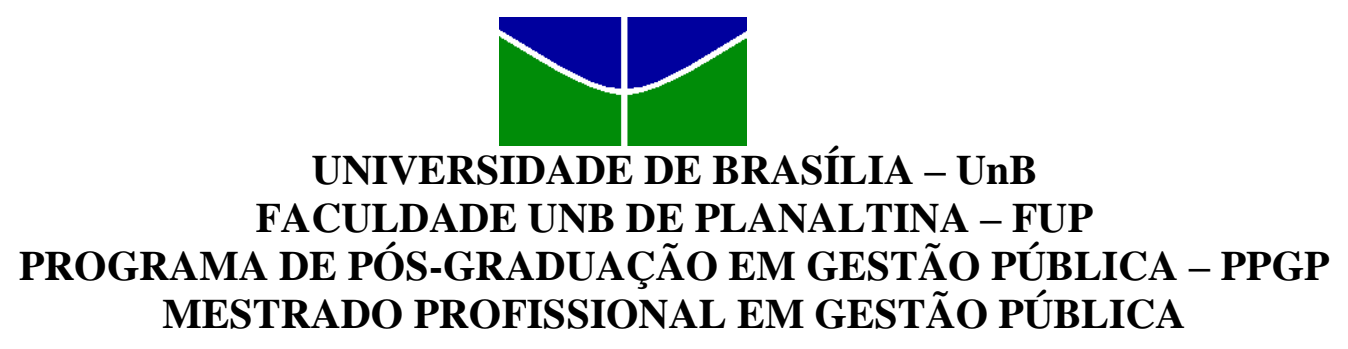

PEDRO VIEIRA DA SILVA

AVALIAÇÃO E IMPORTÂNCIA DOS PROGRAMAS DE ASSISTÊNCIA ESTUDANTIL DA UNIVERSIDADE DE BRASÍLIA - UnB

BRASÍLIA - DF 
PEDRO VIEIRA DA SILVA

\title{
AVALIAÇÃO E IMPORTÂNCIA DOS PROGRAMAS DE ASSISTÊNCIA ESTUDANTIL DA UNIVERSIDADE DE BRASÍLIA - UnB
}

\begin{abstract}
Dissertação apresentada ao Programa de PósGraduação em Gestão Pública para conclusão do Mestrado Profissional em Gestão Pública da Faculdade de Planaltina da Universidade de Brasília, como requisito para obtenção do título de Mestre em Gestão Pública.
\end{abstract}

Orientador: Prof. Dr. Alexandre Nascimento de Almeida.

BRASÍLIA - DF

Junho/2016 
Ficha catalográfica elaborada automaticamente, com os dados fornecidos pelo(a) autor(a)

\section{Vieira da Silva, Pedro}

VS586a AVALIAÇÃO E IMPORTÂNCIA DOS PROGRAMAS DE ASSISTÊNCIA ESTUDANTIL DA UNIVERSIDADE DE BRASILIA UnB / Pedro Vieira da Silva; orientador Prof. Dr. Alexandre Nascimento de Almeida. -- Brasilia, 2016. $90 \mathrm{p}$.

Dissertação (Mestrado - Mestrado Profissional em Gestăo Pública) -- Universidade de Brasilia, 2016.

1. Assistência Estudantil;. 2. Avaliação de Políticas Públicas; 3. Democratização do Ensino Superior.. I. Nascimento de Almeida, Prof. Dr. Alexandre, orient. II. Título. 


\title{
PROGRAMA DE PÓS-GRADUAÇÃo EM GESTÃo PÚBLICA - PPGP MESTRADO PROFISSIONAL EM GESTÃO PÚBLICA
}

\author{
PEDRO VIEIRA DA SILVA
}

\section{AVALIAÇÃO E IMPORTÂNCIA DOS PROGRAMAS DE ASSISTÊNCIA ESTUDANTIL DA UNIVERSIDADE DE BRASÍLIA - UnB}

Aprovada em sua versão final pelos abaixo assinados:

Prof. Dr. Alexandre Nascimento de Almeida - Orientador

Profa. Dra. Denise Bomtempo Birche de Carvalho - Examinadora

Profa. Dra. Carolina Cássia Batista Santos - Examinadora

Prof. Dr. Luiz Honorato da Silva Júnior (Suplente) 
Dedico esta dissertação a minha esposa, Maria Eugênia, pelo carinho e apoio recebidos durante o Mestrado. A meus filhos, Pedro Henrique e João Paulo; meus amores, minha vida. Aos meus irmãos e a meus pais Benedito e Corina (in memorian) pela dedicação e incentivo a mim sempre dados. 


\section{AGRADECIMENTOS}

A Deus, pela concretização deste momento. A minha esposa, Maria Eugênia Meireles Vieira, meu amor, pela compreensão e carinho nas minhas ausências. A meus filhos, Pedro Henrique e João Paulo, meus amores e minha razão de viver.

Agradeço, imensamente, a meu Orientador, Prof. Dr. Alexandre Nascimento de Almeida, que concordou em orientar-me sob os ditames da justiça, da ética, do profissionalismo e da dedicação integral. O professor Alexandre Nascimento de Almeida ministra seus ensinamentos de forma bastante singular, pois ele é acima de tudo Humano e dignifica sua maestria.

Agradeço, também, às Professoras Doutoras Denise Bomtempo Birche de Carvalho e Carolina Cássia Batista Santos, que prontamente autorizaram a pesquisa junto à Diretoria de Desenvolvimento Social/DDS/DAC/UnB. Da mesma forma, registro meus agradecimentos à equipe da DDS/DAC, Sra. Luísa Marques da Rocha Baumgarten, Diretora da DDS, Sr. Rafael Zonta, Coordenador de Administração da DDS/DAC; à Mestra em Educação Amanda Veloso, Pedagoga, lotada na DDS/DAC; à Vera Lúcia Reis, Secretária Executiva, lotada na DDS/DAC e ao Mestre em Economia, Mendel Queiroz; Administrador, também lotado na DDS/DAC; todos eles são profissionais bastantes dedicados à Assistência Estudantil.

Registro, meus agradecimentos ao Engenheiro Márcio Marianno Lisboa, meu Diretor na Prefeitura do campus/UnB. Da mesma forma, agradeço a todos os profissionais lotados na Diretoria de Manutenção Predial da Prefeitura do campus, de forma especial à Administradora Alcilene Sant'ana de Lima, com quem divido minhas tarefas diárias na Prefeitura do campus; bem como aos Engenheiros - Francely de Fátima Mendes Pereira e Arnaldo Gratão, pelo apoio durante este mestrado na UnB.

Agradeço, também, à Profa. Dra. Ana Cláudia Farranha, pelo profissionalismo e dedicação à arte da docência.

Agradeço à Doutora Katia Alves dos Santos, que soube proceder de maneira firme e profissional no momento certo, praticamente na reta final do mestrado.

Agradeço à Mestra em Economia Nilzith de Souza Miranda e à economista Wilma Rezende, pelo apoio e atenção. 
Agradeço muitíssimo à revisora do texto Professora Jackeline Ferreira Barbosa.

Agradeço, imensamente, aos estudantes que gentilmente participaram desta pesquisa estudantes participantes do Grupo: Assistência de Verdade não é Caridade.

Finalmente, registro meus agradecimentos aos colegas da Primeira Turma de Mestrado em Gestão Pública da Faculdade UnB Planaltina/FUP/UnB: Aristides Alvares Dourado Junior; Ivonaldo Vieira Neres; Kelli Adriane de Carvalho; Laura Cristina Menezes Nunes; Lussara Ribeiro Vieira Marques; Priscilla Kettilyn Rosa de França; Ricardo Borges Oliveira; Rivany Borges Beú e Rogério Luiz Alves dos Santos. No momento, em que tudo estava prestes a ruir, eles não me deixaram perder o foco. Essa Turma possibilitou um mestrado alegre, criativo, e dinâmico. Com essa Turma foi muito bom fazer pesquisa; apresentar seminários e viajar para Lisboa/Portugal, por meio do Convênio celebrado com o Instituto Superior de Ciências Sociais e Políticas da Universidade de Lisboa (ISCSP) e a Universidade de Brasília/UnB, onde realizamos pesquisas sobre modelos de gestão pública. 


\section{RESUMO}

A democratização do ensino superior é uma estratégia de combate da desigualdade social, porém, a inclusão efetiva de estudantes em vulnerabilidade socioeconômica na universidade demanda a implementação eficaz de programas de assistência estudantil. Portanto, o objetivo geral da pesquisa é analisar a assistência estudantil na Universidade de Brasília - UnB. Em específico, o trabalho buscou: 1) avaliar os programas de assistência estudantil da UnB; 2) identificar os principais problemas dos Restaurantes Universitários (RUs) e da Casa do Estudante (CEU) da UnB; 3) avaliar o desempenho acadêmico e as dificuldades peculiares dos estudantes em vulnerabilidade socioeconômica; 4) estimar o impacto de algumas dificuldades do estudante em vulnerabilidade socioeconômica no seu desempenho acadêmico. Para tanto, foram analisados 189 questionários respondidos por estudantes beneficiados pela assistência estudantil da UnB, empregando os métodos: estatística descritiva, análise de cluster e análise de regressão múltipla. Em geral, os programas de assistência estudantil que oferecem algum recurso financeiro direto receberam sugestões para a atualização do valor e críticas aos constantes atrasos no pagamento. O programa de auxílio alimentação foi bem avaliado, destacando sugestões para o pagamento de valor monetário suficiente nos casos em que o beneficiário comprovar dificuldade de ter acesso ao RU. O programa de auxílio emergencial se mostrou limitado no atendimento do seu objetivo, os motivos foram a sua pouca divulgação e a burocracia e lentidão na concessão do benefício. O programa de acesso à língua estrangeira, na sua essência, não apresentou maiores críticas. O grande problema desse programa é o descompasso entre a oferta e a demanda de vagas, limitando o seu acesso. O programa vale livro se mostrou pouco eficaz devido, principalmente, ao seu pequeno benefício, apenas $10 \%$ de desconto, e a sua restrição para a compra de livros publicados somente pela editora da UnB. A avaliação dos RUs da UnB foi positiva. Exceto pela qualidade do suco e variedade do cardápio, em geral, as questões referentes à higiene, ao horário de funcionamento, à qualidade e à quantidade da comida, entre outras, foram caracterizadas com uma qualidade boa, muito boa ou excelente. Tal como o RU, a avaliação da CEU foi positiva, destacando alguns problemas como o acesso limitado da internet, a falta constante de água e a indisponibilidade de servidores para a realização de pequenos consertos como, por exemplo, o de chuveiro queimado. Os resultados não indicaram um desempenho acadêmico inferior do estudante em vulnerabilidade socioeconômica e nem maiores problemas de assédio moral com esse perfil de estudante. Porém, os resultados foram conclusivos no indicativo de que as dificuldades consequentes da necessidade de trabalhar, da insuficiência dos programas de assistência estudantil e da pior formação no ensino médio limitam o desempenho acadêmico do estudante em vulnerabilidade socioeconômica.

Palavras-chave: assistência estudantil, avaliação de políticas públicas, democratização do ensino superior. 


\begin{abstract}
The democratization of higher education is a strategy to combat social inequality, however, the inclusion of students in socioeconomic vulnerability at the university demand the effective implementation of student assistance programs. Therefore, the objective of the research is to analyze the student assistance at UnB. Specifically, the study sought to: 1) evaluate the student assistance programs at $\mathrm{UnB} ; 2$ ) identify the main problems of the University Restaurants (URs) and the Student House (SH) of UnB; 3) evaluate the academic performance and the peculiar difficulties of needy students; 4) estimate the impact of some difficulties of needy students in their academic performance. Therefore, it was analyzed 189 questionnaires answered by students benefit from assistance of UnB by methods: descriptive statistics, cluster analysis and multiple regression analysis. In general, student assistance programs that provide some direct financial resource for the students received suggestions for updating of the value and criticism of the constant delays in payment. The food aid program has been well evaluated, highlighting suggestions for the payment of sufficient monetary value in cases where the beneficiary proves difficulties to have access to UR. The emergency aid program has proved limited in meeting its objective, the reasons were their little promotion and bureaucracy and slowness in granting the benefit. Access to foreign language program, in essence, showed no major criticism. The big problem of this program is the mismatch between supply and demand for places, limiting access to the benefit. The program of book coupon proved ineffective, mainly due to its small benefit, only $10 \%$ off, and its restriction to the purchase of books published solely by the publisher of UnB. The assessment of URs of UnB were positive. Except for the juice quality and variety of the menu, in general, issues relating to hygiene, hours of operation, the quality and quantity of food, among others, were characterized with good, very or excellent quality. Like UR, the evaluation of the SH was positive, highlighting some problems such as limited access to the internet, the permanent lack of water and the unavailability of servers to perform small repairs, for example, burned shower. The results did not indicate a lower academic performance of the socioeconomic vulnerability students and even greater bullying problems with this student profile. However, the results were conclusive to indicate that the consequent difficulties by need to work, inadequacy of student assistance programs and the worst formation in high school limit the academic performance of the student in socioeconomic vulnerability.
\end{abstract}

Keywords: student assistance, evaluation of public policies, higher education democratization. 


\section{LISTA DE ILUSTRAÇÕES}

TABELAS

Tabela 1. Número médio das refeições servidas por mês para os restaurantes da UnB

Tabela 2. Resumo dos resultados da avaliação dos programas de assistência estudantil da UnB

Tabela 3. Resumo dos resultados da avaliação dos RUs da UnB. 53

\section{QUADROS}

Quadro 1. Programas de Assistência Estudantil da UnB

Quadro 2. Críticas dos estudantes para melhoria do Programa de Auxílio Socioeconômico .. 41

Quadro 3. Alguns comentários dos estudantes para melhoria do Programa Moradia

Estudantil/Graduação.

Quadro 4. Algumas críticas dos estudantes para melhoria do Programa Auxílio Alimentação

Quadro 5. Algumas críticas dos estudantes para melhoria do Programa Bolsa Permanência do

Ministério da Educação

Quadro 6. Algumas críticas dos estudantes para melhoria do Programa Auxílio Emergencial

Quadro 7. Algumas críticas dos estudantes para melhoria do Programa de Acesso a Língua Estrangeira.

Quadro 8. Algumas críticas dos estudantes para melhoria do Programa Vale Livro 50

Quadro 9. Algumas críticas dos estudantes em vulnerabilidade socioeconômica para melhoria dos RUs

Quadro 10. Algumas críticas dos estudantes em vulnerabilidade socioeconômica para melhoria dos serviços prestados na CEU

Quadro 11. Algumas críticas dos estudantes em vulnerabilidade socioeconômica para melhoria da infraestrutura da CEU

Quadro 12. Alguns comentários em relação às dificuldades do estudante em vulnerabilidade socioeconômica 


\section{FIGURAS}

Figura 1. Conhecimento, Importância e Qualidade dos programas de assistência da UnB.....39

Figura 2. Percentual das críticas ou sugestões apontadas pelos estudantes para melhoria do Programa de Auxílio Socioeconômico

Figura 3. Percentual das críticas ou sugestões apontadas pelos estudantes para melhoria do Programa Moradia Estudantil/Graduação

Figura 4. Percentual das críticas ou sugestões apontadas pelos estudantes para melhoria do Programa de Auxílio Alimentação

Figura 5. Percentual das críticas ou sugestões apontadas pelos estudantes para melhoria do Programa Bolsa Permanência do Ministério da Educação

Figura 6. Percentual das críticas ou sugestões apontadas pelos estudantes para melhoria do Programa Auxílio Emergencial

Figura 7. Percentual das críticas ou sugestões apontadas pelos estudantes para melhoria do Programa de Acesso à Língua Estrangeira

Figura 8. Percentual das críticas ou sugestões apontadas pelos estudantes para melhoria do Programa Vale Livros

Figura 9. Avaliação da qualidade de diversos aspectos dos RUs da UnB 52

Figura 10. Percentual das críticas ou sugestões dos alunos para melhoria dos RUs da UnB...54

Figura 11. Avaliação da infraestrutura, serviço e convivência entre os estudantes na CEU....56

Figura 12. Percentual das críticas ou sugestões apontadas pelos estudantes em vulnerabilidade socioeconômica para melhoria dos serviços prestados na CEU

Figura 13. Percentual das críticas ou sugestões apontadas pelos estudantes para melhoria da infraestrutura da CEU

Figura 14. Desempenho acadêmico dos Estudantes em Vulnerabilidade Socioeconômica..... 61

Figura 15. Possíveis dificuldades enfrentadas pelos estudantes em vulnerabilidade socioeconômica

Figura 16. Dificuldades enfrentadas pelos estudantes em vulnerabilidade socioeconômica ...67 


\section{LISTA DE ABREVIATURAS E SIGLAS}

AAt - Agilidade do Atendimento

ANDIFES - Associação Nacional dos Dirigentes das Instituições Federais de Ensino Superior

B - Bom

BID - Banco Interamericano do Desenvolvimento

BM - Banco Mundial

CAC - Câmara de Assuntos Comunitários

CAD - Conselho de Administração

CEPLAN - Centro de Planejamento da UnB

CEU - Casa do Estudante Universitário

DA - Desempenho Acadêmico

DAC - Decanato de Assuntos Comunitários

DDS - Diretoria de Desenvolvimento Social

DF - Distrito Federal

E - Excelente

EH - Espaços para Higiene das Mãos e Banheiros

FCE - Faculdade UnB Ceilândia

FIAD - Formação Insuficiente no Ensino Médio para Acompanhar as Disciplinas

FONAPRACE - Fórum Nacional de Pró-Reitores de Assuntos Comunitários e Estudantis

FUP - Faculdade UnB Planaltina

HF - Horário de Funcionamento

IFES - Instituição Federal de Ensino Superior

IPAE - Insuficiência dos Programas de Assistência Estudantil

LPT - Limpeza dos Pratos e Talheres

LR - Limpeza do Refeitório

MB - Muito Bom

MEC - Ministério da Educação

MPNE - Mesa Permanente de Negociação com os Estudantes

OMC - Organização Mundial do Comércio 
PAA - Programa Auxílio Alimentação

PAE - Programa Auxílio Emergencial

PALE - Programa Acesso à Língua Estrangeira

PBP/MEC - Programa Bolsa Permanência do Ministério da Educação

PME/G - Programa Moradia Estudantil - Graduação

PNAES - Programa Nacional de Assistência Estudantil

PASeUnB - Programa Auxílio Socioeconômico da Universidade de Brasília

PVL - Programa Vale Livro

QA - Qualidade dos Alimentos

QS - Qualidade do Suco

QtdA - Quantidade do Alimento Servido

R -Ruim.

RA - Razoável

REUNI - Reestruturação e Expansão das Universidades

RU - Restaurante Universitário

SA - Situação Atual (trabalhando ou não)

SAEWEB - Sistema de Assistência Estudantil WEB

SAM - Sofrimento com Assédio Moral

SECOM - Secretaria de Comunicação Social da UnB

TR - Tamanho do Refeitório

UFMG - Universidade Federal de Minas Geral

UFPB - Universidade Federal da Paraíba

UFPR - Universidade Federal do Paraná

UFRJ - Universidade Federal do Rio de Janeiro

UFRR - Universidade Federal de Roraima

UnB - Universidade de Brasília

UTFPR - Universidade Tecnológica Federal do Paraná

VC - Variedade do Cardápio 


\section{SUMÁRIO}

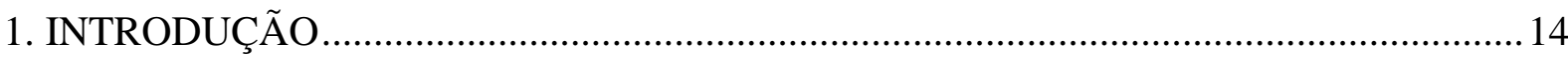

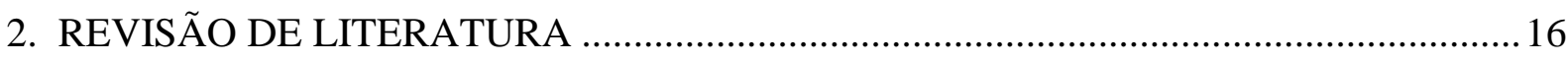

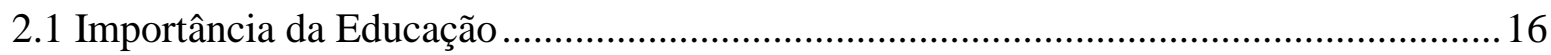

2.2 Ampliação e Democratização das Vagas no Ensino Superior ........................................ 18

2.3 Programa Nacional de Assistência Estudantil (PNAES) .............................................. 21

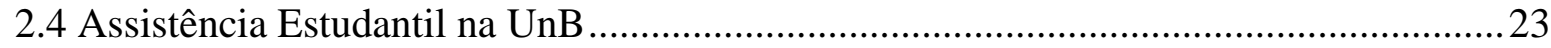

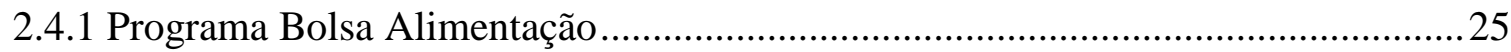

2.4.2 Programa Moradia Estudantil da Graduação ........................................................ 26

2.4.3 Programa Auxílio Socioeconômico (PASeUnB) e Programa Bolsa Permanência

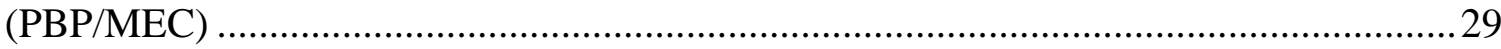

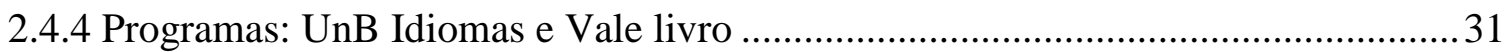

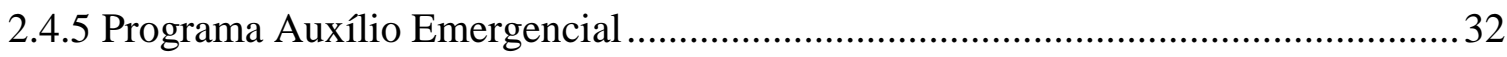

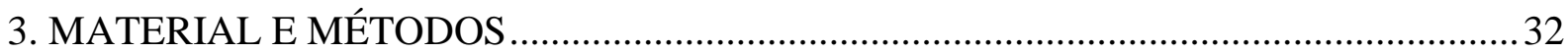

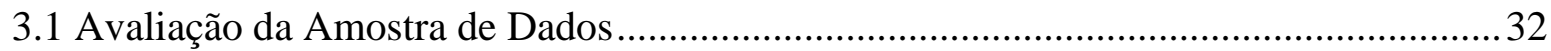

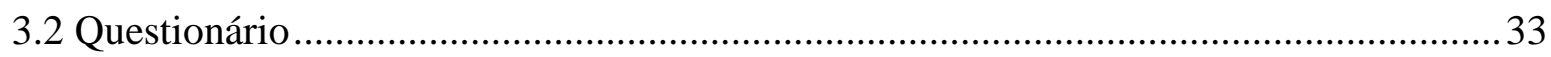

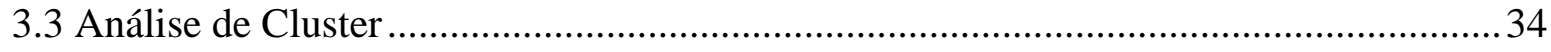

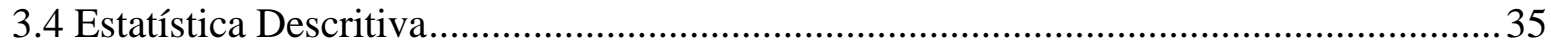

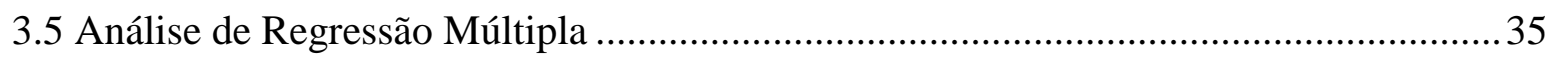

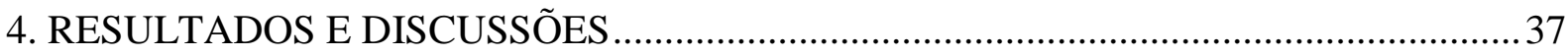

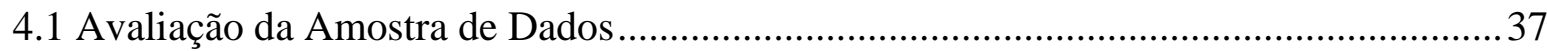

4.2 Avaliação dos Programas de Assistência Estudantil da UnB ...................................... 37

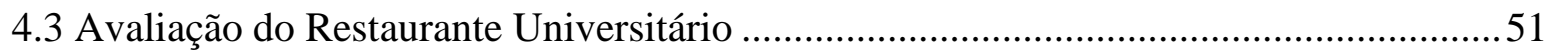

4.4 Avaliação da Casa do Estudante Universitário (CEU) …..............................................55

4.5 Desempenho Acadêmico e Dificuldades Peculiares dos Estudantes em Vulnerabilidade

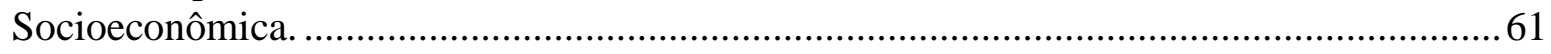

4.6 Impacto das Dificuldades do Estudante em Vulnerabilidade Socioeconômica no seu

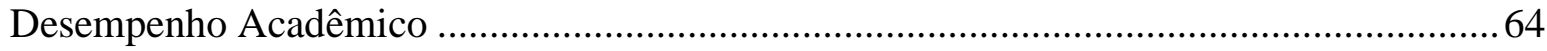

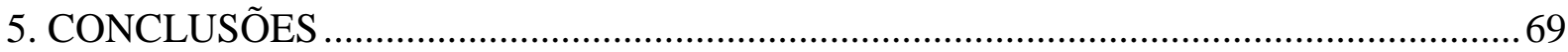

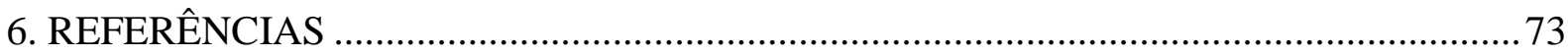

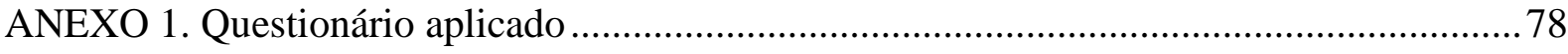




\section{INTRODUÇÃO}

A assistência estudantil visa garantir a permanência e a formação acadêmica com qualidade para os estudantes em situação de vulnerabilidade socioeconômica no ensino superior. Assim, a assistência estudantil compõe um conjunto de ações desenvolvidas no campo da educação que visam prover as condições (materiais e imateriais) necessárias à permanência dos estudantes na universidade.

Vulnerabilidade socioeconômica é um conceito multidimensional que se refere ao resultado de qualquer processo acentuado de exclusão, discriminação ou enfraquecimento de indivíduos ou grupos, provocado por fatores, tais como: pobreza, crises econômicas, nível educacional deficiente, localização geográfica precária e baixos níveis de capital social, humano, ou cultural, entre outros, que gera fragilidade dos atores no meio social (KAZTMAN, 2001).

Apesar de as ações de assistência estudantil serem, praticadas no Brasil desde os anos de 1930 (NASCIMENTO, 2014), apenas recentemente passou a ter uma maior repercussão, destacando a aprovação do decreto 7.234/2010 que instituiu o Programa Nacional de Assistência Estudantil/PNAES. A prioridade desse decreto é o atendimento aos estudantes em vulnerabilidade social, provenientes da rede pública de educação básica ou com renda per capita de até um salário mínimo e meio (BRASIL, 2010).

As ações assistenciais previstas no PNAES devem ser desenvolvidas nas seguintes áreas: moradia estudantil, alimentação, transporte, atenção à saúde, inclusão digital, cultura, esporte, creche, apoio pedagógico. Cabendo a cada Instituição Federal de Ensino Superior (IFES) a definição dos critérios e a metodologia de seleção dos estudantes em vulnerabilidade social matriculados nos cursos graduação, presencial, a serem beneficiados.

Dentre as ações de assistência estudantil na Universidade de Brasília (UnB), estão os programas: Alimentação, Socioeconômico; Emergencial; Moradia Estudantil da Graduação; 
Acesso à Língua Estrangeira e Vale Livro; que têm o caráter de integração social com o objetivo de assegurar aos estudantes em situação de vulnerabilidade socioeconômica condições equânimes de inserção, permanência com qualidade, participação na vida universitária e diplomação. Com a política de expansão e democratização do ensino promovida pelo REUNI na UnB, a adesão a essa política ocorreu em 19 de outubro de 2007 (Ata 333a CONSUNI de 2007). Com a adesão da UnB, ao Sistema de Seleção Unificada/SISU, ocorrida no primeiro semestre de 2014, o volume de recursos destinados para a política de assistência estudantil aumentou. Entre 2009 e 2016 o número de alunos beneficiados pela assistência estudantil na UnB quintuplicou, saltando de menos de mil alunos beneficiados em 2009 para quase cinco mil em 2015 (DDS/DAC 2016).

Para ter acesso aos Programas de Assistência Estudantil na UnB o estudante precisa participar do processo de análise socioeconômica, regido por edital e publicado no início de cada semestre letivo pelo Decanato de Assuntos Comunitários (DAC) por meio da sua Diretoria de Desenvolvimento Social (DDS). A análise socioeconômica é realizada por uma equipe técnica de assistentes sociais, tendo como finalidade conhecer o perfil socioeconômico dos estudantes, para então cadastrá-los nos programas oferecidos pela universidade.

Embora seja possível destacar o empenho do DAC/DDS na implementação das políticas de assistência estudantil na UnB nos últimos anos, pouco tem sido feito para avaliar a efetividade das ações adotadas, justificando a avaliação dos Programas de Assistência Estudantil da UnB.

A avaliação dos Programas de Assistência Estudantil da UnB pode subsidiar o planejamento e formulação de políticas na universidade, auxiliando o acompanhamento, a implementação e possíveis reformulações ou ajustes dos programas de assistência estudantil, assim como, as decisões sobre a manutenção ou interrupção dos mesmos. A avaliação é um 
instrumento importante para a eficiência do investimento do DAC/DDS, tendo como propósito alcançar uma melhoria contínua nas suas ações e gestão.

Assim, buscando identificar o conhecimento e a avaliação que os estudantes têm sobre os Programas de Assistência Estudantil da UnB e a forma como esses programas têm atuado na rotina acadêmica dos mesmos, o objetivo geral da pesquisa é analisar a assistência estudantil na UnB. Em específico, o trabalho buscou:

- Avaliar os Programas de Assistência Estudantil da UnB;

- Identificar os principais problemas dos Restaurantes Universitários (RUs) e da Casa do Estudante da UnB (CEU);

- Avaliar o desempenho acadêmico e as dificuldades peculiares dos estudantes em vulnerabilidade socioeconômica; e

- Estimar o impacto de algumas dificuldades do estudante em vulnerabilidade socioeconômica no seu desempenho acadêmico.

O interesse pelo presente estudo refere-se ao fato de esse pesquisador ter participado na administração da Assistência Estudantil na Universidade de Brasília/UnB, no período de 2007 a 2012; no gabinete do Decanato de Assuntos Comunitários/DAC/UnB, como um dos técnico-administrativos do quadro permanente da UnB que atuou e contribuiu para a gestão da Assistência Estudantil.

\section{REVISÃO DE LITERATURA}

\subsection{Importância da Educação}

A educação é esboçada como um bem público a serviço do setor privado, isto é, ela visa à formação de trabalhadores (capital humano) para exercerem os diferentes papéis demandados pelo mercado, dando ênfase ao contribuinte e ao empregador ao em vez do cidadão (enfatizado no modelo de igualdade). Nesse caso, ela se destina a preparar pessoas 
para serem bem sucedidas na competição por espaços onde consigam ocupar os papéis de mercado mais desejados e as melhores posições sociais (LABAREE, 1997).

Rezende (2010, p. 26), vis-à-vis os aspectos de rivalidade e exclusão, classificou a educação como um bem misto ou semipúblico, já que possui tanto características de bens públicos como de bens privados:

[...] até determinado limite, não há diferença se em uma sala de aula entra um novo estudante, ou seja, não há rivalidade de consumo do serviço (a aula). Há, todavia, capacidade de facilmente excluir alguém do consumo, o que a enquadra, assim, na categoria de bem semipúblico.

Para Hutchinson (1960, p. 10) todos os níveis educacionais vinculam-se a status sociais de origem e para mantê-los ou ascender a status mais elevados que os de seus pais, cada indivíduo deve obter níveis educacionais mais elevados do que àqueles vinculados a sua classe de origem. Ele considera, entretanto, que "a eficiência desse meio aparentemente simples de mudar o status social é rigorosamente restringida pelas dificuldades que o indivíduo enfrenta ao querer uma educação mais elevada do que a esperada pela sua classe”. Para Hutchinson (1960) a universidade é uma ferramenta poderosa de manutenção e ascensão social, restrita, em grande parte, para as pessoas com alto poder aquisitivo.

Ioschpe (2004) aponta outras variáveis que podem ter impactos sobre a demanda e o aprendizado como, por exemplo, o desenvolvimento tecnológico, a escolaridade dos professores, a infraestrutura ou manutenção das escolas, o prestígio dos diplomas da instituição no mercado de trabalho e a localização da universidade na cidade onde reside o estudante, impactando na distância percorrida e em seus custos de acesso à educação. Ele afirma que o desenvolvimento tecnológico é o principal fator gerador dos aumentos na demanda por educação, visto que a necessidade de pessoas alcançarem maiores níveis educacionais aumentará à medida que as novas tecnologias exigirem delas a aquisição de novos conhecimentos, habilidades e atitudes. 
Voltado inicialmente para uma restrita clientela dotada de capital econômico e cultural, o ensino superior passou a incorporar gradativamente novos grupos sociais, que até então estavam às suas margens, em função de pressões sociais para sua democratização. As matrículas no ensino superior praticamente duplicaram nos quatro cantos do mundo: em 1975, somavam pouco mais de 40 milhões de estudantes e, em 1995, superaram a cifra de 80 milhões e, para que essa democratização ocorresse em sua plenitude, tornou-se necessária a ampliação de diversos programas voltados para a assistência estudantil (MARTINS, 2006).

\subsection{Ampliação e Democratização das Vagas no Ensino Superior}

A reformulação da educação no Brasil a partir dos anos de 1990 teve como objetivos: o alívio da pobreza, que se amplia e se aprofunda nos países da periferia, constituindo a política educacional como uma política de segurança do capital; a difusão de um novo projeto de sociabilidade burguesa e a constituição de uma promissora área de investimentos para o capital internacional em busca de novos mercados e novos campos de exploração lucrativa (LIMA, 2007).

As políticas para a educação superior no Brasil nessa época inseriram-se no contexto de subordinação do país à economia global, à agenda neoliberal e às ideias disseminadas por organismos multilaterais, como Banco Mundial (BM), o Banco Interamericano do Desenvolvimento (BID) e a Organização Mundial do Comércio (OMC) (SGUISSARDI, 2006).

Dentre as questões mais graves desse modelo, Sguissardi (2006) destacou: o desinteresse dos estudantes pelo modelo de ensino praticado; a desistência dos estudantes; a má formação do professor; os problemas de infraestrutura de muitas escolas; e o baixo nível de aprendizado, agravado pelo acúmulo de defasagens anteriores.

Diante deste cenário, o Programa de Apoio a Planos de Reestruturação e Expansão das Universidades Federais (REUNI) que foi divulgado por meio do Decreto Presidencial 
6096/2007 contou com os seguintes objetivos: elevar a taxa de conclusão dos cursos de graduação para 90\%; aumentar o número de estudantes de graduação nas universidades federais; aumentar o número de alunos por professor em cada sala de aula da graduação; diversificar as modalidades dos cursos de graduação, por meio da flexibilização dos currículos, da criação dos cursos de curta duração e/ou ciclos (básico e profissional) e da educação a distância, incentivando a criação de um novo sistema de títulos e a mobilidade estudantil entre as instituições (públicas ou privadas). Todas estas ações deverão ser realizadas no prazo de cinco anos (BRASIL, 2007).

O REUNI, se propôs, também, a criar mais condições para a ampliação do acesso e permanência na educação superior. Entre as diretrizes esboçadas pelo programa destacam-se: a redução das taxas de evasão, a ocupação de vagas ociosas, o aumento de vagas de ingresso, especialmente no período noturno e a ampliação de políticas de inclusão e assistência estudantil (BRASIL, 2007). Outras medidas como o aumento da oferta de cursos superiores a distância e a política de cotas também contribuíram para reverter os índices baixíssimos de inclusão no nível superior de ensino (BARROS, 2015).

Especificamente no caso da expansão da educação superior espera-se que ela agregue não apenas mais alunos, mas que se possa perceber uma maior independência entre suas origens sociais e seu desempenho acadêmico, escolha de carreiras e permanência nos cursos, o que concorreria para promover uma real democratização do ensino superior. Em outras palavras, interessa à sociedade brasileira uma expansão com qualidade acadêmica e inclusiva (VARGAS, 2010).

A expansão universitária na UnB teve início em 2008, com a aplicação de recursos do REUNI, e se deu por meio da ampliação de vagas nos cursos de graduação, criação de cursos noturnos e construção de novos prédios e três campi em regiões periféricas de Brasília, localizados nas cidades satélites de Ceilândia, Gama e Planaltina. O objetivo da expansão e 
democratização das vagas foi claramente alcançado, pois a UnB, no primeiro semestre de 2014, contou com 36.027 estudantes regulamentes matriculados, ou seja, 15.385 estudantes a mais quando comparado com o número de alunos no final do ano de 2007, o que representa um crescimento percentual de 75\% após a implementação do REUNI (UnB, 2014).

Por outro lado, conforme Brito (2013), algumas críticas e impasses podem ser questionadas em relação aos resultados do REUNI na UnB como, por exemplo: a) crescimento desordenado dos cursos, sem muitas vezes, atender ao interesse da sociedade; b) precarização da mão de obra docente; c) expansão de vagas em cursos que não possuíam demanda efetiva; d) criação de cursos sem pesquisa de mercado e sem espaço para seus respectivos egressos; e) necessidade de formação para o corpo de servidores da universidade; f) necessidade do repensar crítico sobre a universidade e a perspectiva de recriá-la; g) por fim, a ampliação da estrutura física sem a contrapartida na matriz orçamentária.

A evasão segue na contramão da democratização do acesso, pois se por um lado, o jovem brasileiro chega à universidade; por outro, não consegue permanecer e alcançar sucesso em seu projeto inicial, elevando a importância dos Programas de Assistência Estudantil. O REUNI cumpriu a meta de ampliar o número de vagas na UnB, entretanto, não reduziu a taxa de evasão da universidade. Conforme Silva Filho et al. (2007), a taxa média de evasão para os cursos da UnB em 2006, antes do efeito do REUNI, foi de 12,8\%, elevando para 16,1\% após a implementação dessa política. Em geral, tem sido apontando a falta de recursos financeiros do estudante como a principal causa para a interrupção de seus estudos. Porém, é importante que se priorize também a compreensão das questões de ordem acadêmica, como as expectativas do estudante em relação ao curso ou à instituição que podem encorajá-lo ou desestimulá-lo a priorizar a conclusão do seu curso (NERES, 2015).

Gisi (2006) corrobora com essa análise, alegando que é difícil a permanência no ensino superior para os estudantes de camadas sociais mais pobres, não só pela ausência de 
recursos financeiros, mas também pela falta de aquisição de "capital cultural" ao longo da trajetória de sua vida e de seus estudos, o que não se obtém de um momento para o outro. Essa desigualdade cultural é sentida desde a educação básica, quando a maioria dos estudantes inicia seus estudos em desvantagem a outros, em decorrência da ausência de oportunidades que tiveram em relação ao acesso ao conhecimento. Reconhecer essas desigualdades deve ser o passo inicial para a qualidade na educação, caso contrário, haverá muitos estudantes com acesso no ensino superior, mas poucos deverão apropriar-se do conhecimento que o processo de ensino e aprendizagem exige. Conforme Buarque (2012, p. 83):

\begin{abstract}
A universidade tem que integrar a educação de base no Brasil. Hoje são mundos que se acham separados. Olham-se como estranhos. Fruto do elitismo e das divisões sociais. A universidade é culturalmente de elite. Não podemos abandonar a vocação de elite, intrínseca ao ensino [educação] superior, mas temos que dar chance a toda e qualquer pessoa para usar seu talento e fazer parte desta elite, não importa a renda de sua família. Para que a universidade possa progredir, vai precisar de uma educação de base de qualidade, igual para todos [...] A educação de qualidade para todos vai gerar milhões de crianças e jovens alfabetizados nas ciências, ávidos de conhecimento, universitários mais bem preparados, com melhor qualidade educacional. Sem eles, deixados de fora da educação de base, a universidade será sempre medíocre, com qualidade aquém do potencial de seu povo, dos cérebros de sua população.
\end{abstract}

\title{
2.3 Programa Nacional de Assistência Estudantil (PNAES)
}

O Brasil é um dos piores países no que tange à questão do índice de distribuição de renda do mundo, conforme o Relatório sobre a Distribuição da Renda e da Riqueza da População Brasileira, publicado pela Secretaria de Política Econômica do Ministério da Fazenda, em 9/5/2016). No Brasil, a parcela do $1 \%$ mais rica da população possui 48,5\% da renda dos 5\% mais ricos. Mas é preciso reconhecer que o Estado interfere na economia e na educação com ações programáticas, com o propósito de diminuir as lacunas existentes na sociedade brasileira, ofertando um ensino superior gratuito e programas de manutenção dos estudantes na universidade (FONAPRACE, 2011).

Devido à enorme desigualdade social, o Fórum Nacional de Pró-Reitores de Assuntos Comunitários e Estudantis (FONAPRACE, 2011) afirma que grande parte dos matriculados 
nas IFES necessitam de algum tipo de ajuda para sua manutenção nos cursos superiores e, para tanto, a ação governamental para suprir tal necessidade se dá por meio do Programa Nacional de Assistência Estudantil (PNAES).

O PNAES foi instituído pelo Decreto $\mathrm{n}^{\mathrm{o}}$ 7.234, de 19 de julho de 2010 para dar atendimento aos estudantes em vulnerabilidade social, tendo como objetivo garantir a permanência, o bom rendimento acadêmico e a diplomação dos estudantes nas IFES. Atualmente, a única fonte de renda que mantém o Programa Auxílio Socioeconômico da UnB é o orçamento proveniente do PNAES, bem como o que sustenta o Programa Moradia Estudantil e Alimentação.

Conforme Cislaghi e Silva (2011), o PNAES foi concebido no rastro do REUNI em 2007, podendo seus recursos serem aplicados para o desenvolvimento das seguintes áreas: moradia estudantil; alimentação; transporte; atenção à saúde; inclusão digital; cultura; esporte; creche; apoio pedagógico; participação e aprendizagem de estudantes com deficiência, transtornos globais do desenvolvimento e altas habilidades e superdotação.

Por meio dos recursos provenientes do PNAES, o FONAPRACE propôs, a partir do conhecimento do perfil dos estudantes das Universidades Federais e de estudos e debates ocorridos no âmbito do Fórum, bem como, da mobilização de estudantes e de outros setores da comunidade universitária; a criação e a articulação de vários Programas de Assistência Estudantil principalmente aqueles voltados para alimentação, moradia, transporte e permanência, na perspectiva de inclusão social e da melhoria de desempenho dos estudantes de graduação da IFES (ANDIFES, 2011).

Em 2010, a Associação Nacional dos Dirigentes das Instituições Federais de Ensino Superior (ANDIFES) solicitou ao FONAPRACE o mapeamento da vida social, econômica e cultural dos estudantes das IFES; notou-se que um pouco mais da metade dos estudantes das IFES $(55,3 \%)$ pertencem às classes $\mathrm{A}$ e $\mathrm{B}$, que, por sua vez, ocupam as vagas do diurno, 
possivelmente porque não precisam trabalhar para manter seu sustento. Os estudantes das classes C, D e E foram identificados como os que mais utilizam a saúde pública, assim como a moradia e o restaurante universitário.

\subsection{Assistência Estudantil na UnB}

A Diretoria de Desenvolvimento Social (DDS) tem a função de assessorar o Decanato de Assuntos Comunitários (DAC) no planejamento, implantação, operacionalização e monitoramento dos programas, projetos e ações da política de assistência estudantil desenvolvida na Universidade de Brasília.

Conforme Alves (2009), a finalidade da assistência estudantil consiste em prover aos universitários o acesso aos recursos necessários para a superação de empecilhos que porventura possam prejudicar seu desempenho acadêmico. Desse modo, ela estaria relacionada a diversos setores dos direitos humanos, e por isso ela contempla, além dos meios financeiros para a manutenção do estudante durante o curso, cuidados relacionados à saúde, alimentação, lazer, entre outros.

A política de assistência estudantil tem a finalidade de ampliar as condições de acesso e permanência dos jovens na educação superior pública federal, o que implica o desenvolvimento de estratégias de inclusão social, democratização do acesso, permanência e formação acadêmica com qualidade, evitando a retenção e a evasão do estudante em situação de vulnerabilidade socioeconômica.

O público-alvo da política de assistência estudantil na Universidade de Brasília é amplo e diversificado, expandindo-se a cada início de semestre, especialmente após a UnB aderir ao REUNI. Essas novas demandas imprimem novos desafios. Diante da diversidade de necessidades dos estudantes participantes dos programas, a UnB, por meio da DDS/DAC, vem criando estratégias para garantir o direito à assistência estudantil. 
A assistência estudantil da UnB foi constituída por um conjunto de programas e ações de garantia de direitos de cidadania aos estudantes. Os programas sociais oferecidos têm como objetivo assegurar aos estudantes em situação de vulnerabilidade socioeconômica condições equânimes de inserção, permanência com qualidade, participação na vida universitária e diplomação (DDS/2015).

Para se ter acesso aos diversos programas de assistência estudantil que a UnB oferece, o estudante tem de participar do processo de análise socioeconômica, regido por edital e publicado no início de cada semestre letivo. Podem participar dos programas sociais os estudantes regularmente matriculados em disciplinas dos cursos presenciais de graduação e de pós-graduação, identificados pelo serviço social em situação de vulnerabilidade socioeconômica.

A UnB oferece seis benefícios (Quadro 1), além do Programa Bolsa Permanência do Ministério da Educação, todos eles estão previstos no PNAES do Governo Federal. Os programas são financiados pela Fundação Universidade de Brasília (FUB) e pelo MEC.

Quadro 1. Programas de Assistência Estudantil da UnB

\begin{tabular}{|l|}
\hline Bolsa Alimentação \\
Refeições gratuitas no Restaurante Universitário (RU) dos campi Darcy Ribeiro, Ceilândia, Planaltina e \\
Gama. \\
\hline Moradia Estudantil \\
Vaga na Casa do Estudante Universitário (CEU) ou auxílio mensal no valor de R\$ 530,00 (quinhentos e \\
trinta reais) para estudantes não residentes no Distrito Federal. \\
\hline Auxílio Socioeconômico \\
Ajuda financeira de R $\$ 465,00$ (quatrocentos e sessenta e cinco reais) com foco no apoio pedagógico. Busca \\
reduzir desigualdades sociais. \\
\hline Auxílio Emergencial \\
Cobre situações imprevistas e momentâneas de estudantes que estão desvinculados dos Programas de \\
Assistência Estudantil. \\
\hline Bolsa Permanência do MEC \\
Auxílio no valor de R $\$ 400,00$ (pago pelo Ministério da Educação para estudantes matriculados em cursos \\
com carga horária letiva diária de cinco horas ou mais. \\
\hline UnB Idiomas \\
Cursos gratuitos na escola de línguas da UnB (parceria DDS e Escola de Línguas/UnB). \\
\hline Vale livro \\
Desconto de $10 \%$ na compra de livros da Editora UnB, acumuláveis aos $40 \%$ concedidos a todos os alunos da \\
Universidade (parceria DDS e Editora UnB). \\
\hline
\end{tabular}

Fonte: DDS/UnB, 2015. 


\subsubsection{Programa Bolsa Alimentação}

O Programa Bolsa Alimentação é desenvolvido em parceria com o Restaurante Universitário (RU). Consiste na concessão de subsídio nos preços das refeições servidas pelo RU: café da manhã, almoço e jantar para o aluno em vulnerabilidade socioeconômica. No seu início, o benefício englobava apenas o almoço e o jantar. Em 2011, o RU passou a servir o café da manhã a esse grupo de alunos. Em uma perspectiva quantitativa, no ano de 2008, foram atendidos 913 estudantes. Já em agosto de 2012, este número aumentou para 2.443 estudantes beneficiados, demonstrando o avanço no atendimento pelo programa (RU/UnB, 2012).

Estudantes, professores e técnico-administrativos podem fazer suas refeições no RU da UnB, que também é aberto à comunidade em geral. Há unidades nos campi Darcy Ribeiro, Ceilândia, Gama, Planaltina e na Fazenda Água Limpa. No campus Darcy Ribeiro, o restaurante funciona durante toda a semana. Nos demais campi é aberto apenas nos dias úteis. O RU do campus Darcy Ribeiro foi inaugurado em 1975 e foi projetado para atender um maior número de alunos, já os RUs dos campi de Ceilândia, Gama e Planaltina foram inaugurados recentemente, entre 2014 e 2015, e possuem projetos similares para atender um número menor de usuários. O RU da Fazenda Água Limpa foi inaugurado em 2013, é voltado, principalmente, para os servidores da fazenda e para os alunos das áreas de ciências agrárias e biológicas que realizam aulas práticas e atividades de campo na fazenda.

O RU tem o objetivo de fornecer refeições a preços baixos, balanceadas, saudáveis e com boa qualidade. Os valores cobrados variam de acordo com a classificação do usuário nos grupos I, II, III e IV. O grupo I é composto por estudantes indígenas e estudantes que fazem parte dos programas de assistência estudantil, esses não pagam pela alimentação. Estudantes estrangeiros oriundos de países em desenvolvimento com os quais o Brasil mantém acordos educacionais e culturais (PEC-G) fazem parte do grupo II e pagam $\mathrm{R} \$ 1,00$ pela refeição. $\mathrm{O}$ 
grupo III, composto pelos demais estudantes e servidores da UnB, o valor da refeição é de R\$ 2,50. Para visitantes da comunidade em geral (grupo IV) o preço da refeição é de $\mathrm{R} \$ 9,00$ no café da manhã e R\$ 15,00 no almoço ou jantar (RU/UnB, 2015).

No refeitório do Darcy Ribeiro são servidas, mensalmente, mais de 130 mil refeições. Por dia, nesse campus, são produzidos cerca de $300 \mathrm{Kg}$ de feijão, $260 \mathrm{Kg}$ de arroz e $1.000 \mathrm{Kg}$ de carne. Nas outras unidades, é fornecido número menor de refeições. A quantidade de refeições servidas mensalmente e por grupo, em média para o ano de 2015, dos RUs da UnB se encontram na Tabela 1.

Tabela 1. Número médio das refeições servidas por mês para os restaurantes da UnB

\begin{tabular}{cccccc}
\hline RU & Grupo I & Grupo II & Grupo III & Grupo IV & Total \\
\hline Darcy Ribeiro & 368.115 & 36.045 & 1.143 .854 & 13.490 & 1561503 \\
FAL & 2.151 & 122 & 10.278 & 176 & 12.727 \\
FGA & 37.701 & 90 & 99.893 & 153 & 137.837 \\
FCE & 34.116 & 1.979 & 73.569 & 378 & 110.042 \\
FUP & 44.923 & 816 & 14.960 & 196 & 60.895 \\
Total & 487.006 & 39.052 & 1.342 .553 & 14.393 & 1.883 .004 \\
\hline
\end{tabular}

Fonte: RU/UnB, 2015.

Além dos Programas Bolsa Alimentação e Auxílio Alimentação, a DDS/DAC desenvolve uma ação complementar ao Programa Bolsa Alimentação. Os estudantes participantes do Programa Moradia Estudantil da Graduação (PME/G) recebem um auxílio alimentação complementar para os dias em que o RU não estiver em funcionamento no valor de $\mathrm{R} \$ 15,00$ (quinze reais) por dia. Em 2015, o quantitativo de estudantes atendidos por este auxílio complementar foi de 970 (novecentos e setenta) estudantes.

\subsubsection{Programa Moradia Estudantil da Graduação}

O Programa Moradia Estudantil oferece moradia temporária na Casa do Estudante Universitário (CEU) ou Auxílio Pecúnia aos estudantes de graduação em situação de vulnerabilidade socioeconômica, prioritariamente, aqueles com família residente fora do Distrito Federal (DF) ou provenientes de regiões de difícil acesso ao campus de origem. A 
moradia estudantil se caracteriza como um dos principais mecanismos para garantir a permanência desse grupo de estudantes na universidade.

Os encaminhamentos dos estudantes para este programa são realizados pela DDS/DAC durante os semestres letivos, conforme disponibilidade de vagas identificadas. $\mathrm{O}$ complexo de moradia estudantil da CEU/UnB é composto por dois blocos, localizados no campus Darcy Ribeiro, atualmente com 90 apartamentos do tipo duplex e equipados com eletrodomésticos e móveis, que são organizados para receber 04 estudantes, totalizando 360 vagas (DDS, 2015).

Os prédios que compõem a CEU foram construídos em 1973 e se encontravam com as estruturas físicas deterioradas, com infiltrações, vazamentos, risco de desabamento em algumas áreas, danos na rede hidráulica, de esgoto e elétrica. Devido a isso, ocorreu uma completa reforma na CEU/UnB; O lançamento do edital de contratação de empresa para a reforma foi lançado em agosto de 2011, segundo o Centro de Planejamento/CEPLAN/UnB e finalizada em 2014. A reforma da CEU foi uma reivindicação antiga dos estudantes. Ao longo do processo de planejamento dessa reforma, os estudantes tiveram participação efetiva na discussão e tomada de decisões, que foram democratizadas em audiências públicas, reuniões realizadas na CEU e na Mesa Permanente de Negociação com os Estudantes (MPNE).

Conforme, divulgação feita pela Secretaria de Comunicação Social da UnB/SECOM, a UnB inaugurou no dia 13 de janeiro de 2010, a Mesa Permanente de Negociação com os Estudantes participantes da Assistência Estudantil (MNPE). A MNPE foi um fórum onde os estudantes e a Administração Superior da UnB, discutiram as reivindicações do movimento estudantil, realizando avaliação e acompanhamento contínuo das questões em pauta. A Mesa Permanente foi composta de 16 (dezesseis) membros, oito da administração e oito dos estudantes (SECOM/UnB, 2010). 
A MNPE não substituiu outros órgãos deliberativos da universidade, como a Câmara de Assuntos Comunitários do Decanato de Assuntos Comunitários/CAC/DAC. Conforme Resolução do Conselho de Administração da UnB/CAD/UnB, compete a CAC: emitir pareceres, analisar propostas e projetos, regulamentar normas do CAD e apreciar recursos de decisões dos Conselhos de Institutos e de Faculdades, quando atenderem os critérios de admissibilidade. A MNPE ajudou a construir consensos entre estudantes e administração; caracterizando-se como um fórum permanente que permitiu iniciar várias discussões que já acontecem no Diretório Central dos Estudantes da UnB/DCE.

A Secretaria de Comunicação Social da UnB/SECOM noticiou, em junho/2011, que o primeiro ponto de pauta da MNPE foi à reforma da Casa do Estudante Universitário/CEU, que estava parada devido às divergências sobre onde alocar os moradores durante a realização da obra. A reitoria havia oferecido alojamentos no Minas Tênis Clube e em outros clubes da cidade, mas os estudantes recusaram. Eles pediram que a UnB alugasse apartamentos na Asa Norte/DF, o que também não foi aceito. Desta forma, foi criado um grupo de trabalho para elaborar novas propostas. $\mathrm{O}$ acordo que ficou estabelecido com os 252 (duzentos e cinquenta e dois) moradores em situação regular oferecia um auxílio de $\mathrm{R} \$$ 510,00 para que em grupo locassem imóveis (SECOM/UnB, 2011). No primeiro semestre de 2014, esse Programa foi reajustado para $\mathrm{R} \$ 530,00$.

O Recurso financeiro utilizado para manutenção da reforma foi proveniente do PNAES. A DDS/DAC, para garantir melhor qualidade de vida aos estudantes, pretende equipar os 90 (noventa) apartamentos reformados na CEU com geladeira, fogão, máquina de lavar, televisão, forno micro-ondas e camas com recursos que serão adquiridos via PNAES. O programa de moradia estudantil oferece vagas aos estudantes participantes nas modalidades: a) vaga em apartamento na CEU; b) concessão mensal de auxílio financeiro no valor de $\mathrm{R} \$ 530,00$ (quinhentos e trinta reais) quando não houver disponibilidade de vagas na 
CEU e na existência de quotas em pecúnia mediante disponibilidade orçamentária. Aos estudantes dos campi de Ceilândia, Gama e Planaltina o benefício da moradia estudantil é disponibilizado em forma de pecúnia (DDS, 2015).

Os encaminhamentos dos estudantes para o Programa Moradia Estudantil da Graduação são realizados pela DDS/DAC durante os semestres letivos, conforme a disponibilidade de vagas e segundo edital específico. Em 2015, 1.197 estudantes foram beneficiados. Desses estudantes, residiram na CEU 288 e receberam auxílio moradia em forma de pecúnia 957 estudantes (DDS, 2015).

O tempo de permanência do estudante na CEU é de até dois semestres além do tempo regular do seu curso. Não poderão hospedar amigos e parentes com exceção dos estudantes deficientes que necessitem dos seus cuidadores. O estudante poderá perder a vaga quando da ocorrência das seguintes hipóteses: ausentar-se da CEU por mais de 15 dias consecutivos, mesmo em período de férias, caso não tenha a anuência da administração da CEU, ou em caso de desobediência de regras de convivência, conforme Ato da Reitoria da UnB nº 1200/2014).

\subsubsection{Programa Auxílio Socioeconômico (PASeUnB) e Programa Bolsa Permanência (PBP/MEC)}

O Programa Auxílio Socioeconômico (PASeUnB), criado pela resolução no 12/2014 do $\mathrm{CAD} / \mathrm{UnB}$, concede auxílio financeiro aos estudantes, no valor de $\mathrm{R} \$ 465,00$ (quatrocentos e sessenta e cinco reais) que, identificados pela DDS/DAC, se encontram em vulnerabilidade socioeconômica (CAD/UnB, 2014). Esse auxílio é concedido mensalmente e tem a finalidade de complementação financeira, a fim de evitar a evasão e o abandono de curso dos discentes por falta de recursos financeiros. Conforme dados da DDS (2016), o programa auxiliou 2.432 alunos em 2015.

O estudante que for beneficiado pelo PASeUnB pode acumular, com mais uma bolsa ou auxilio, decorrente do desenvolvimento de atividades de ensino, pesquisa e extensão, mas 
a soma total dos valores não pode ultrapassar um salário mínimo e meio. O estudante beneficiado poderá acumular também outros auxílios fornecidos pela assistência estudantil, mas também não pode ultrapassar a soma de um salário mínimo e meio, com exceção dos campi que não possuem RU.

O estudante em situação de vulnerabilidade social para receber o PASeUnB deve estar matriculado em curso de graduação presencial e ter concluído o mínimo de créditos do fluxo de seu curso no semestre, conforme o Projeto Político Pedagógico (PPP) do curso, não ser portador de diploma de curso superior, não ultrapassar dois semestres do tempo regulamentar do referido curso e não participar do programa bolsa permanência do MEC. Caso o estudante apresente dois ou mais trancamentos de disciplinas e notas inferiores a "MM" (médio), este será encaminhado ao Serviço de Orientação ao Universitário do Decanato de Ensino de Graduação da Universidade de Brasília (SOU/DEG/UnB), a fim de verificar o seu desempenho acadêmico, com base em seu histórico escolar e sua regularidade com o plano de curso (CAD/UnB, 2014).

O Programa Bolsa Permanência (PBP/MEC) é uma ação do Governo Federal de concessão de auxílio financeiro a estudantes matriculados em instituições federais de ensino superior em situação de vulnerabilidade socioeconômica e para estudantes indígenas e quilombolas. O PBP/MEC é um auxílio financeiro que tem por finalidade minimizar as desigualdades sociais e contribuir para a permanência e a diplomação dos estudantes de graduação em situação de vulnerabilidade socioeconômica. Seu valor, estabelecido pelo MEC, é equivalente ao praticado na política federal de concessão de bolsas de iniciação científica, atualmente de $\mathrm{R} \$ 400,00$ (quatrocentos reais). Para os estudantes indígenas e quilombolas, é garantido um valor diferenciado, igual a pelo menos o dobro da bolsa paga aos demais estudantes, em razão de suas especificidades com relação à organização social de suas comunidades, condição geográfica, costumes, línguas, crenças e tradições, amparadas pela 
Constituição Federal, atualmente no valor de $\mathrm{R} \$ 900,00$ (novecentos reais). O recurso é pago diretamente ao estudante de graduação por meio de um cartão de benefício.

O PBP/MEC é oferecido para estudantes nas seguintes condições: ter renda familiar per capita não superior a um salário-mínimo e meio; estar matriculado em cursos de graduação com carga horária média superior ou igual a cinco horas diárias; não ter ultrapassado dois semestres do tempo regulamentar do curso de graduação em que estiver matriculado; e ser de etnia indígena ou quilombola (MEC, 2013).

A UnB, por meio da DDS/DAC, aderiu ao PBP/MEC e tem a função de realizar o estudo socioeconômico para a seleção e inscrição dos estudantes, homologar as inscrições para pagamentos dos estudantes e proceder ao acompanhamento social e acadêmico dos participantes do programa. No ano de 2015, 826 (oitocentos e vinte e seis) estudantes foram atendidos por esse programa (DDS, 2015).

Os estudantes em situação de vulnerabilidade socioeconômica dos cursos de Ciência da Computação, Ciências Farmacêuticas, Educação do Campo, Enfermagem, Farmácia, Gestão da Saúde, Medicina, Odontologia, Pedagogia, Engenharia Mecatrônica, e Terapia Ocupacional poderão se inscrever no Sistema do MEC (MEC, 2013).

\subsubsection{Programas: UnB Idiomas e Vale livro}

O Programa de Acesso à Língua Estrangeira (PALE) é uma parceria com a UnB Idiomas, que disponibiliza até duas vagas por turma com a isenção da cobrança de matrículas e mensalidades aos estudantes cadastrados na assistência estudantil. Essa parceria se iniciou em 2010 e, recentemente, em negociação com a direção da escola de idiomas, houve a possibilidade de ampliação do número de vagas para alunos em vulnerabilidade socioeconômica conforme o número de alunos por turma.

O Programa Vale Livro (PVL), é uma parceria com a Editora UnB, que oferece ao estudante participante dos programas de assistência estudantil cinco vales em cada semestre 
letivo, que dão direito a $10 \%$ de desconto, além do desconto de $40 \%$ já oferecido aos demais estudantes, na compra de materiais pedagógicos e livros editados pela Editora da UnB.

\subsubsection{Programa Auxílio Emergencial}

O Programa Auxílio Emergencial (PAE) é destinado aos estudantes regularmente matriculados em cursos presenciais de graduação, que se encontram em situação de vulnerabilidade socioeconômica inesperada e momentânea e que, prioritariamente, não estejam inseridos em programas de assistência estudantil da universidade. Em conformidade com a Resolução 0109/2013 da Reitoria da UnB, essas situações são analisadas pela equipe de assistentes sociais e pela DDS/DAC. O valor do benefício é de $\mathrm{R} \$ 465,00$ (quatrocentos e sessenta e cinco reais) e apenas o primeiro auxílio pode ser pago a estudantes que não tenham estudo socioeconômico realizado pela DDS/DAC. O estudante poderá receber até o limite de três auxílios no semestre se a situação de vulnerabilidade inesperada e momentânea persistir. De acordo com a resolução supracitada o limite médio de auxílios emergenciais é de 25 mensais.

\section{MATERIAL E MÉTODOS}

\subsection{Avaliação da Amostra de Dados}

Os dados desta pesquisa foram obtidos por meio da aplicação de questionário eletrônico para a população dos estudantes beneficiados pela assistência estudantil da UnB. O período de coleta durou 45 dias, ocorrendo nos meses de novembro e dezembro de 2015 e contou com apoio da DDS/DAC, que enviou comunicação eletrônica (e-mail) para 1.938 (um mil, novecentos e trinta e oito) estudantes participantes do Programa Auxílio Socioeconômico/PASeUnB, cadastrados no SAEWEB no ano de 2014. Lembrando que o estudante beneficiado pelo PASeUnB pode acumular, com mais uma bolsa ou auxilio, decorrente do desenvolvimento de atividades de ensino, pesquisa e extensão. 
No intuito de ampliar o tamanho da amostra, a pesquisa foi divulgada em redes sociais frequentadas pelos alunos amostrados, bem como, os alunos foram informados sobre a importância da participação na pesquisa por meio de contato direto com os moradores da CEU/UnB, todos eles cadastrados no Sistema de Assistência Estudantil/SAEWEB.

Naturalmente, a efetividade do empenho do pesquisador para a ampliação da amostra é limitada e, a partir dos 45 dias de coleta, percebeu-se que o esforço para a ampliação da amostra já não surtia mais efeito, restando ao pesquisador apenas verificar a margem de erro alcançada e dimensionar a limitação da representatividade da amostra.

Da mesma forma que Silva et al. (2008), a avaliação da margem de erro da amostra se baseou na estimativa da proporção populacional para população finita (Equação 1), admitindo um grau de confiança de $95 \%(1,96)$ no cálculo. A escolha desse método se deve aos dados serem coletados em escala ordinal e ao fato de a população não ser demasiadamente grande, podendo ser considerada como finita (MARTINS, 2006).

$\mathrm{E}=1,96 \sqrt{\frac{0,25}{n-1}\left(\frac{N-n}{N}\right)}$

$\mathrm{E}=$ Margem de erro

$\mathrm{n}=$ Número de indivíduos na amostra

$\mathrm{N}=$ Tamanho da população

\subsection{Questionário}

O questionário aplicado se encontra no Anexo 1 e foi estruturado em cinco blocos com perguntas fechadas e abertas que buscaram coletar informações sobre: 1) conhecimento, importância e qualidade dos programas de assistência estudantil da UnB; 2) qualidade do Restaurante Universitário - RU na percepção do aluno carente; 3) qualidade da moradia na Casa do Estudante Universitário - CEU; 4) desempenho acadêmico e rendimentos proporcionados pelos programas para o estudante em vulnerabilidade socioeconômica; e 5) dificuldades do estudante em vulnerabilidade socioeconômica. 
Além dos cinco blocos de perguntas, o questionário contou com uma pergunta indicativa do campus de origem do aluno, permitindo uma análise comparativa entre a qualidade do RU do campus Darcy Ribeiro com os restaurantes dos campi da UnB na Ceilândia, Gama e Planaltina. Os RUs dos campi de Ceilândia, Gama e Planaltina foram analisados em agregado dado a semelhança dos seus projetos.

A base teórica que subsidiou a elaboração do questionário contou com as seguintes referências: Bourdieu (1982); Brasil (1988); Carvalho (2006); Ioschpe (2004); Germano (2004); Gilioli (2006); Lahire (2002); Mancebo (2004); Reuni (2007); Silva (2006); Vasconcelos (2004) e Zago (2006).

\subsection{Análise de Cluster}

A Análise de Cluster (AC) é uma técnica útil para detectar grupos homogêneos de variáveis por meio de medidas de similaridade. Aplicou-se a AC para verificar o agrupamento das variáveis relacionadas à qualidade do RU, da CEU e dos Programas de Assistência Estudantil da UnB conforme os atributos: excelente, muito bom, bom, razoável e ruim. Bem como se utilizou da mesma técnica para verificar o grau de importância e conhecimento dos programas de assistência estudantil da UnB.

A medida de similaridade adotada foi a distância euclidiana, adotando o algoritmo hierárquico na formação dos agrupamentos. Conforme Hair Jr. et al. (2005), a distância euclidiana é a medida de similaridade mais utilizada e a opção pelo algoritmo hierárquico se deve ao caráter exploratório da pesquisa.

No método hierárquico os clusters formam-se com base nos pares de indivíduos mais próximos de acordo com a medida de similaridade escolhida. $\mathrm{O}$ algoritmo continua passo a passo, juntando pares de indivíduos, pares de clusters ou um indivíduo com um cluster, até que todos os dados estejam em um só cluster, resultando em um dendograma (PESTANA \& GAGEIRO, 2005). 
O procedimento adotado para a ligação dos clusters foi o da ligação completa ou do vizinho mais afastado. Segundo Pestana e Gageiro (2005), esse é um dos métodos mais utilizados, sendo baseado na distância máxima entre objetos em dois agrupamentos (a distância entre os membros mais diferentes de cada agrupamento). Em cada estágio da aglomeração, os dois agrupamentos com a menor distância máxima (mais semelhantes) são combinados (HAIR Jr. et al., 2005)

A AC não é uma técnica de inferência estatística, permitindo uma ampla aplicabilidade devido a sua grande liberdade de pressupostos estatísticos. Entretanto, não existe nenhum procedimento padrão e objetivo para determinar o número final de clusters a serem interpretados, sendo utilizados procedimentos ad hoc para esse fim. A decisão do número final de clusters a serem interpretados buscou alcançar o menor número de agrupamentos e não comprometer a sua interpretação.

\subsection{Estatística Descritiva}

A estatística descritiva foi empregada para avaliar o desempenho acadêmico e as dificuldades normalmente enfrentadas pelos estudantes em vulnerabilidade socioeconômica e, também, para resumir o conteúdo das respostas expressas nas perguntas abertas do questionário, valorizando a simplicidade peculiar dessa análise e permitindo uma leitura rápida dos resultados.

Para tanto, calculou-se a porcentagem das respostas das categorias de interesse, apresentando em gráficos do tipo "pizza", nos casos do número de categorias ser igual ou inferior a quatro, ou de barras quando o número de categorias superar esse valor.

\subsection{Análise de Regressão Múltipla}

O objetivo da análise de regressão foi avaliar o impacto de possíveis dificuldades enfrentadas pelos estudantes em vulnerabilidade socioeconômica no seu desempenho acadêmico. Segundo Leal Lobo et al. (2007), Gomes et al. (2010) e Baggi e Lopes (2011), as 
dificuldades normalmente enfrentadas pelos estudantes são: 1) a necessidade de trabalhar, não permitindo uma dedicação exclusiva aos estudos; 2) a insuficiência dos programas de assistência estudantil no suprimento das necessidades dos alunos; 3) a maior dificuldade para acompanhar as disciplinas devido a uma fraca formação no ensino médio; 4) possíveis problemas de assédio moral enfrentado pelos estudantes em vulnerabilidade socioeconômica.

Assim, conforme a Equação 2, o modelo assumiu como variável dependente o desempenho acadêmico dos estudantes em vulnerabilidade socioeconômica e como variáveis explicativas as possíveis dificuldades que esses estudantes enfrentam dado a sua condição de vulnerabilidade socioeconômica. Junto com a Equação 2 foram apresentadas as codificações utilizadas na tabulação dos dados, facilitando o entendimento dos resultados.

$\mathrm{DA}=\beta_{1}+\beta_{2} \mathrm{SA}+\beta_{3}$ IPAE $+\beta_{4}$ FIAD $+\beta_{5}$ SAM

Em que:

DA = Desempenho acadêmico ("1" entre os piores estudantes, "2" entre 50\% dos estudantes com melhor desempenho, "3" entre $20 \%$ dos estudantes com melhor desempenho, "4" entre $10 \%$ dos estudantes com melhor desempenho)

SA = Situação atual ("0" Não Trabalhando e "1" Trabalhando)

IPAE = Insuficiência dos programas de assistência estudantil ("1" discordo completamente, "2" discordo, "3" indiferente, "4" concordo e "5" concordo completamente)

FIAD = Formação insuficiente no ensino médio para acompanhar as disciplinas ("1" discordo completamente, "2" discordo, "3" indiferente, "4" concordo e "5" concordo completamente) SAM = Sofrimento de assédio moral ("1" discordo completamente, "2" discordo, "3" indiferente, "4" concordo e "5" concordo completamente).

A Equação [2] foi estimada pelo método dos Mínimos Quadrados Ordinários (MQO) e as hipóteses são de que os estudantes que estão trabalhando ou que a assistência estudantil não é suficiente, bem como, aqueles que são vítimas de assédio moral ou que tiveram uma 
formação insuficiente no ensino médio, tendem a ter um pior desempenho acadêmico. Portanto, conforme as codificações adotadas, as direções esperadas dos sinais dos coeficientes foram: $\beta_{2}, \beta_{3}, \beta_{4}<0$ e $\beta_{5}>0$. Todas as hipóteses foram avaliadas pelo teste $t$ unicaudal, admitindo um nível de significância de $10 \%$.

O diagnóstico de possíveis problemas econométricos do modelo decorrentes de multicolineariedade, heteroscedasticidade e autocorrelação ocorreram, respectivamente, por meio do: indicador do Fator de Inflação da Variância (FIV), do teste BPG de Breusch e Pagan (1979) e pela estatística $d$ de Durbin-Watson. Da mesma forma que para o teste $t$, o julgamento da presença dos problemas de heteroscedasticidade e autocorrelação considerou um nível de significância de $10 \%$.

\section{RESULTADOS E DISCUSSÕES}

\subsection{Avaliação da Amostra de Dados}

A amostra alcançada foi de 189 (cento e oitenta e nove) questionários respondidos, correspondendo a aproximadamente $10 \%$ da população de alunos cadastrados no Programa Auxílio Socioeconômico/PASeUnB até o segundo semestre de 2014. A relação entre o tamanho da amostra e a população esteve de acordo com as sugestões de Nazareth (1999). Segundo a autora, a representatividade do grupo objeto do estudo deve ser garantida no mínimo por $10 \%$ do número total da população alvo.

A margem de erro calculada para a amostra foi de 6,7\% para mais ou para menos e esteve inferior ao aceito na pesquisa de realizada por Lira (2008), Almeida (2010), Neres (2015) e Cancian (2016).

\subsection{Avaliação dos Programas de Assistência Estudantil da UnB}

A AC agrupou três conjuntos de variáveis que se mostraram similares conforme o grau de conhecimento, importância e qualidade dos programas de assistência estudantil da UnB (Figura 1). Conforme a Tabela 2, os grupos formados na AC foram classificados em: 
- Grupo (1): variáveis com maior grau de conhecimento, importância e qualidade;

- Grupo (2): variáveis com grau intermediário de conhecimento, importância e qualidade; e

- Grupo (3): variáveis com menor grau de conhecimento, importância e qualidade.

Os programas de assistência estudantil mais importante na percepção dos estudantes foram: PASeUnB - Programa Auxílio Socioeconômico; PAA - Programa Auxílio Alimentação e PME/G - Programa Moradia Estudantil da Graduação. Esses resultados demonstraram uma maior preocupação dos estudantes em vulnerabilidade socioeconômica com necessidades básicas como, por exemplo, moradia e alimentação, ficando para segundo plano necessidades acadêmicas, emergenciais ou outras necessidades de caráter específico (Tabela 2).

Dentre os programas mais importantes, apenas PAA (Programa Auxílio Alimentação) alcançou o maior grau de qualidade e PASeUnB o maior grau de conhecimento, sugerindo ações prioritárias do $\mathrm{DAC} / \mathrm{UnB}$ na divulgação dos programas $\mathrm{PAA}$ e $\mathrm{PME} / \mathrm{G}$, bem como, na melhoria do programa PME/G e, principalmente, do PASeUnB. Naturalmente, presume-se que os programas identificados como os de maior importância: PASeUnB, PAA e PME/G, são os prioritários em possíveis intervenções pelos órgãos competentes da UnB (Tabela 2). 
Figura 1. Conhecimento, Importância e Qualidade dos programas de assistência da UnB.
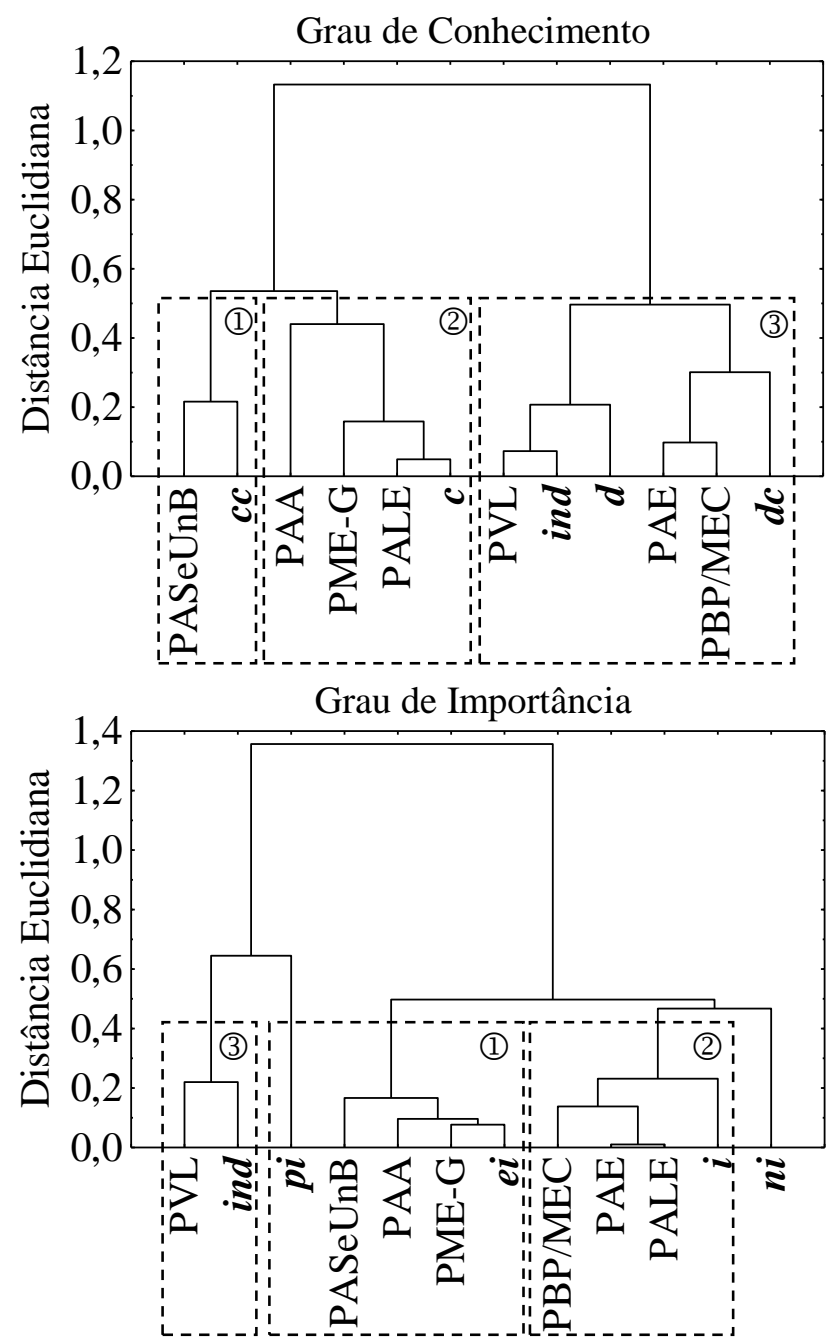

Grau de Qualidade

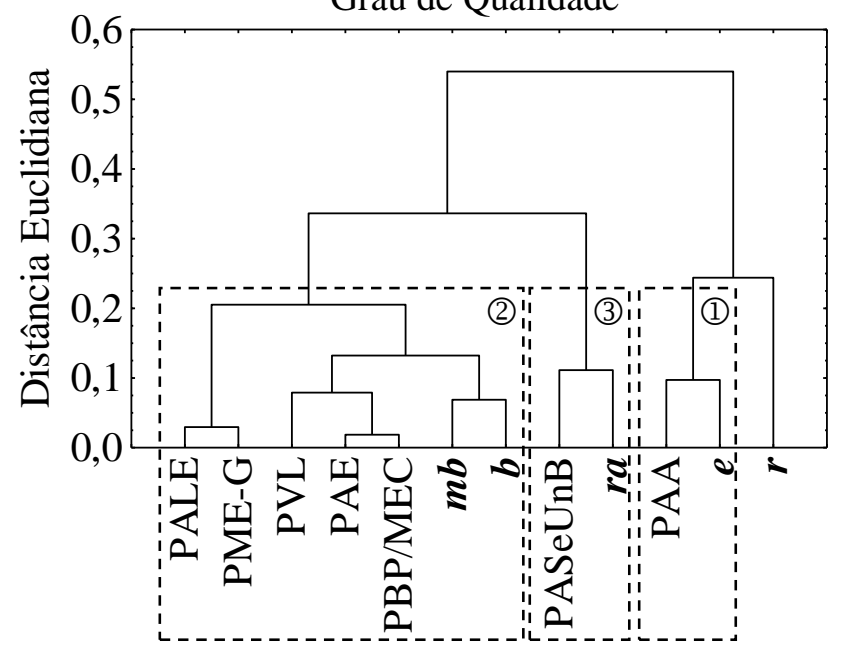

Nota: PASeUnB - Programa Auxílio Socioeconômico; PAA - Programa Auxílio Alimentação; PME/G Programa Moradia Estudantil/Graduação; PALE - Programa de Acesso à Língua Estrangeira; PBP/MEC Programa Bolsa Permanência do MEC; PAE - Programa Auxílio Emergencial; PVL - Programa Vale Livro; $\boldsymbol{c} c$ concordo completamente; $\boldsymbol{c}$ - concordo; ind - indiferente; $\boldsymbol{d}$ - discordo; $\boldsymbol{d} \boldsymbol{c}$ - discordo completamente; $\boldsymbol{e} \boldsymbol{i}$ extremamente importante; $\boldsymbol{i}$ - importante; $\boldsymbol{p} \boldsymbol{i}$ - pouco importante; $\boldsymbol{n} \boldsymbol{i}$ - não importante; $\boldsymbol{e}$ - excelente; $\boldsymbol{m} \boldsymbol{b}$ - muito bom; $\boldsymbol{b}$ - bom; $\boldsymbol{r} \boldsymbol{a}$ - razoável; $\boldsymbol{r}$ - ruim. 
Tabela 2. Resumo dos resultados da avaliação dos programas de assistência estudantil da UnB

\begin{tabular}{cccc}
\hline Grupos & Conhecimento & Importância & Qualidade \\
\hline Maior & PASeUnB & PASeUnB, PAA e PME/G & PAA \\
Intermediário & AA, PME/G e PALE & PBP/MEC, PAE e PALE & PALE, PME/G, PVL, \\
& & & PAE e PBP/MEC \\
Menor & PVL, PAE e PBP/MEC & PVL & PASeUnB
\end{tabular}

Nota: PASeUnB - Programa Auxílio Socioeconômico; PAA - Programa Auxílio alimentação; PME/G Programa Moradia Estudantil/Graduação; PALE - Programa de Acesso à Língua Estrangeira; PBP/MEC Programa Bolsa Permanência do Ministério da Educação; PAE - Auxílio Emergencial; PVL - Vale Livro.

O conteúdo das críticas ou sugestões dos estudantes para melhoria do Programa Auxílio Socioeconômico (PASeUnB) se concentraram no baixo valor do benefício, destacando a sua falta de atualização e nos constantes atrasos no pagamento. Em seguida, destacaram-se problemas como a insuficiência de bolsas e dificuldades no processo de inscrição e renovação para o cadastramento no programa. Com um número reduzido de comentários, foram apontadas dificuldades de obter informações por parte da DDS e uma insuficiência no controle e fiscalização dos beneficiários (Figura 2).

Figura 2. Percentual das críticas ou sugestões apontadas pelos estudantes para melhoria do Programa de Auxílio Socioeconômico

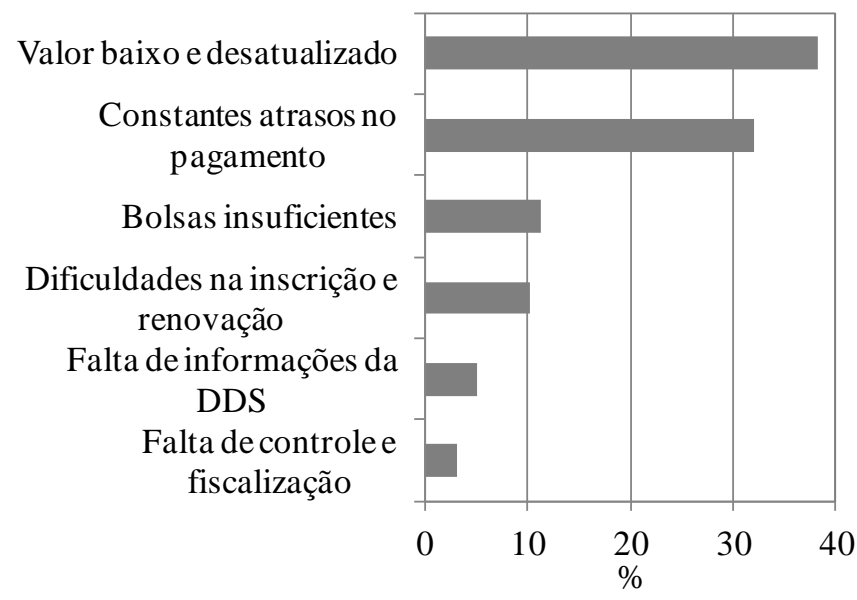

Nota: Número total de sugestões ou críticas para melhoria do PASeUnB igual a 97.

Alguns comentários dos estudantes, representativos das dimensões apresentadas na Figura 2 e voltados para a melhoria do PASeUnB foram apresentados no Quadro 2. 
Quadro 2. Críticas dos estudantes para melhoria do Programa de Auxílio Socioeconômico

\begin{tabular}{|c|c|}
\hline Dimensão & Críticas ou Sugestões dos Estudantes em Vulnerabilidade Socioeconômica \\
\hline $\begin{array}{l}\text { Valor baixo e } \\
\text { desatualizado }\end{array}$ & $\begin{array}{l}\text { - Se o valor do auxílio voltar para um salário mínimo o aluno poderá se dedicar melhor ao } \\
\text { estudo, sem desespero em conseguir outras formas de complementar a renda (Estudante 33). } \\
\text { - O auxílio não acompanha a taxa de inflação do Brasil (Estudante 58). }\end{array}$ \\
\hline $\begin{array}{l}\text { Constantes } \\
\text { atrasos no } \\
\text { pagamento }\end{array}$ & $\begin{array}{l}\text { - O pagamento deve ser realizado até o quinto dia útil, porém, diversas vezes foi pago } \\
\text { atrasado, prejudicando o compromisso de alguns alunos (Estudante 36). } \\
\text { - É um auxílio insuficiente, não dá para fazer muitas coisas com ele. Além de alguns meses } \\
\text { chegar a cair depois do } 5^{\circ} \text { dia útil. Quem tem que receber contas, não está nenhum pouco } \\
\text { preocupado em questão de atrasos (Estudante } 77 \text { ). }\end{array}$ \\
\hline $\begin{array}{c}\text { Bolsas } \\
\text { insuficientes }\end{array}$ & $\begin{array}{l}\text { - No campus de Planaltina não abrem números de bolsas suficientes para estudantes que } \\
\text { participam da assistência estudantil (Estudante 23). } \\
\text { - O auxílio ainda não consegue atender a demanda, o que prejudica alguns alunos (Estudante } \\
\text { 143). }\end{array}$ \\
\hline $\begin{array}{l}\text { Dificuldades na } \\
\text { inscrição e } \\
\text { renovação }\end{array}$ & $\begin{array}{l}\text { - O processo de seleção é muito demorado e muito concorrido. Muitas vezes pessoas } \\
\text { desistem do curso por não conseguirem se manter no curso até o período em que é } \\
\text { contemplada (Estudante 90). } \\
\text { - [...] conheço pessoas que necessitam do recebimento, mas nunca conseguiram aprovação } \\
\text { para entrar nos programas (Estudante 138). }\end{array}$ \\
\hline $\begin{array}{l}\text { Falta de } \\
\text { informações da } \\
\quad \text { DDS }\end{array}$ & $\begin{array}{l}\text { - As assistentes na verdade não prestam assistência. Falta informação. As informações são } \\
\text { sempre desencontradas (Estudante 111). } \\
\text { - Deveria ter mais informações quanto ao pagamento, possíveis atrasos, isso raramente } \\
\text { acontece o que acaba gerando desconforto tanto para os alunos que dependem dessas bolsas, } \\
\text { quanto para os gestores que recebem enxurradas de reclamações e protestos. Deveria haver } \\
\text { mais dialogo (Estudante 186). }\end{array}$ \\
\hline $\begin{array}{l}\text { Falta de } \\
\text { controle e } \\
\text { fiscalização }\end{array}$ & $\begin{array}{l}\text { - Falta de controle e fiscalização de quem recebe a bolsa acaba gerando um remanejamento } \\
\text { das bolsas para pessoas que não precisam, o que acaba ocasionando uma ação em detrimento } \\
\text { de quem precisa (Estudante 40). } \\
\text { - [...] apesar da rigidez para a aprovação dos alunos para tal auxílio, ainda há, alunos que não } \\
\text { necessitam e estão recebendo no lugar de quem realmente precisa (Estudante 132). }\end{array}$ \\
\hline
\end{tabular}

Outras universidades federais do Brasil apresentam programas similares ao PASeUnB pago pela UnB. A Universidade Federal do Rio de Janeiro (UFRJ) mantém a Bolsa Auxílio e a Universidade Federal do Paraná (UFPR) concede a Bolsa Permanência. Esses benefícios consistem em uma bolsa de assistência financeira cujo valor atual corresponde a $\mathrm{R} \$ 400,00$ mensais (UFRJ, 2016; UFPR, 2016). A Universidade Federal de Minas Gerais (UFMG) oferece o Programa Bolsa de Manutenção Baeta Vianna, que é um apoio financeiro mensal no valor integral de $\mathrm{R} \$ 400,00$ e parcial de $\mathrm{R} \$ 240,00$, conforme o grau de carência do estudante. Esse programa é destinado aos estudantes que apresentarem situação de vulnerabilidade social e risco de evasão acadêmica em sua primeira graduação (UFMG, 2016).

Conforme os resultados da Tabela 2, o Programa de Moradia Estudantil Graduação (PME/G), pontuado entre os três programas mais importantes da UnB, não se classificou entre 
os programas de melhor qualidade e nem de maior conhecimento, sugerindo uma intervenção da DDS/DAC nesses aspectos para esse Programa.

Tal como o PASeUnB, as principais críticas dos estudantes para o Programa Moradia Estudantil/Graduação (PME/G) - Pecúnia; concerne ao seu baixo valor e atrasos no pagamento. $\mathrm{O}$ pagamento de valores insuficientes obriga os estudantes a alugarem imóveis na periferia do DF, aumentando custos com transporte e dificuldades de locomoção. As demais críticas foram marginais, destacando sugestões para uma flexibilização das regras de inclusão no programa, privilegiando uma análise individualizada de cada caso como, por exemplo, a possibilidade de participação de estudantes que possuem parentes no DF ou que possuam problemas familiares, mesmo que não estejam em condição de vulnerabilidade econômica (Figura 3).

Figura 3. Percentual das críticas ou sugestões apontadas pelos estudantes para melhoria do Programa Moradia Estudantil/Graduação

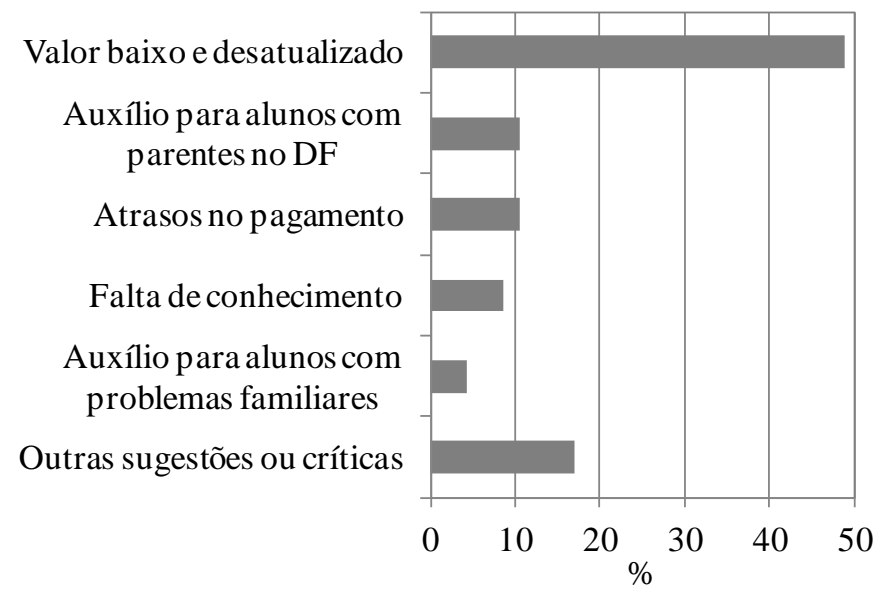

Nota: Número total de sugestões ou críticas para melhoria do PME/G igual a 47.

Outras críticas apontadas ao PME/G se relacionaram com a falta de conhecimento do programa (Figura 3). A explicação desses resultados se deve ao fato que os estudantes em vulnerabilidade socioeconômica, porém, com residência familiar ou de parentes no DF, possuem grandes restrições para participar do programa e, provavelmente, não devem buscar informações sobre o mesmo. 
Um conjunto de opiniões isoladas e diversificadas também foi observado como, por exemplo: o atraso dos editais para inscrição no PME/G, profissionais despreparados da DDS no atendimento aos estudantes, processo muito burocrático, número insuficiente de bolsas, possibilidade de inclusão no programa para quem já cursou uma graduação. Alguns comentários dos estudantes que representam as dimensões da Figura 3 foram apresentados no Quadro 3.

Quadro 3. Alguns comentários dos estudantes para melhoria do Programa Moradia Estudantil/Graduação

\begin{tabular}{|c|c|}
\hline Dimensão & Críticas ou Sugestões dos Estudantes em Vulnerabilidade Socioeconômica \\
\hline $\begin{array}{l}\text { Valor baixo e } \\
\text { desatualizado }\end{array}$ & $\begin{array}{l}\text { - Acredito que perante os gastos mensais que um estudante possa ter durante a graduação } \\
\text { este valor esteja desatualizado em relação à inflação dos preços (Estudante 38). } \\
\text { - Impossível morar em Brasília com } \$ 530 \text { (Estudante 75). }\end{array}$ \\
\hline $\begin{array}{l}\text { Auxílio para } \\
\text { alunos com } \\
\text { parentes no DF }\end{array}$ & $\begin{array}{l}\text { - Mesmo que o estudante tenha parentes morando no DF, deveriam receber o auxilio } \\
\text { dependendo da condição da família e do lugar onde moram (Estudante 51). } \\
\text { - Estender o auxílio mensal a estudantes de baixa renda que têm família no DF (Aluno 52). }\end{array}$ \\
\hline $\begin{array}{l}\text { Atraso no } \\
\text { pagamento }\end{array}$ & $\begin{array}{l}\text { - Auxílio insuficiente para despesas de moradia no Distrito Federal e atrasos constantes } \\
\text { (Estudante 34). } \\
\text { - Atraso no pagamento, valor defasado (Estudante 117). }\end{array}$ \\
\hline $\begin{array}{c}\text { Falta de } \\
\text { conhecimento }\end{array}$ & $\begin{array}{l}\text { - Não tenho conhecimento do programa (Estudante 79). } \\
\text { - Desconhecia essa possibilidade (Estudante 191). }\end{array}$ \\
\hline $\begin{array}{l}\text { Auxílio para } \\
\text { alunos com } \\
\text { problemas } \\
\text { familiares }\end{array}$ & $\begin{array}{l}\text { - Tem estudantes com problemas graves em casa, como de violência, e que deveriam ser } \\
\text { beneficiados com esse programa, desde que se comprove (Estudante } 45 \text { ). } \\
\text { - [...] deveria levar mais em consideração a questão de vulnerabilidade social (Estudante } \\
\text { 182). }\end{array}$ \\
\hline
\end{tabular}

O Programa Auxílio Alimentação (PAA) foi caracterizado entre os mais importantes da UnB, além disso, foi pontuado como o de maior qualidade (Tabela 2). Provavelmente, a alta qualidade do programa tenha refletido nos benefícios de se alimentar no RU, não só pela alimentação gratuita, também pela agilidade, facilidade e possibilidade de integração com os colegas na realização das refeições. Além disso, o oferecimento de recurso em dinheiro nas situações em que o RU é fechado garante uma maior mobilidade de escolha ao estudante e pode ter contribuído para a melhoria da percepção de qualidade do programa.

A qualidade do Programa Auxílio Alimentação (PAA) foi corroborada pelo elevado número de elogios presentes no conteúdo das respostas abertas. Já as sugestões de melhoria se concentraram em tornar o auxílio financeiro para a alimentação como uma alternativa ao RU 
e não como um complemento nos casos em que o RU estiver fechado. Um número menor de críticas apontaram questões como a falta de conhecimento do programa, problemas de gestão e atrasos no pagamento do Auxílio Financeiro (Figura 4).

Figura 4. Percentual das críticas ou sugestões apontadas pelos estudantes para melhoria do Programa de Auxílio Alimentação

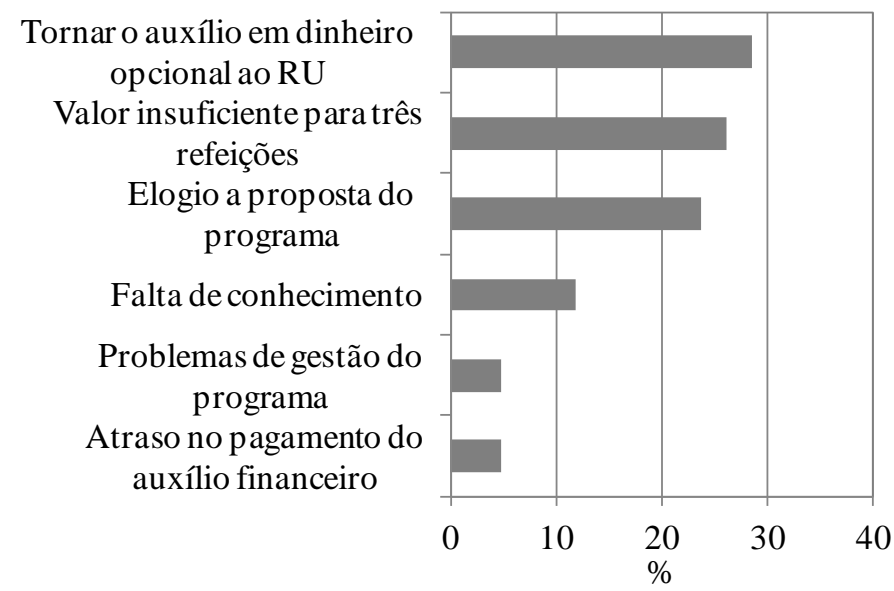

Nota: Número total de sugestões ou críticas para melhoria do PAA igual a 42.

$\mathrm{Na}$ percepção dos estudantes, a presença do RU aberto não garante a sua acessibilidade, destacando várias dificuldades que limitam a obtenção desse benefício como, por exemplo: incompatibilidade do horário de abertura para o jantar, principalmente, para os estudantes do turno noturno; questões familiares e/ou acadêmicas que dificultam a presença do estudante na UnB no horário das refeições; elevada perda de tempo e custo de transporte para os estudantes que moram distante, inviabilizando a ida até a UnB unicamente para realizar sua refeição. Outro foco de críticas é que o recurso oferecido nos casos em que o RU se encontra fechado não é suficiente para adquirir o mesmo benefício do RU aberto, ou seja, o valor atual de $\mathrm{R} \$ 15,00$ (quinze reais) não é o bastante para realizar as três refeições propiciadas pelo RU por dia (Quadro 4). 
Quadro 4. Algumas críticas dos estudantes para melhoria do Programa Auxílio Alimentação

\begin{tabular}{|c|c|}
\hline Dimensão & Críticas ou Sugestões dos Estudantes em Vulnerabilidade Socioeconômica \\
\hline $\begin{array}{l}\text { Tornar o } \\
\text { programa } \\
\text { opcional ao RU }\end{array}$ & $\begin{array}{l}\text { - Quem não faz as refeições no RU poderia continuar recebendo o auxílio em dinheiro. É o } \\
\text { meu caso sou casada tenho uma filha e tenho que ir para casa almoçar e jantar, não posso } \\
\text { ficar todo o período no campus (Estudante 25). } \\
\text { - Nas férias/final de semana, muitos estudantes não vão ao Ru comer por que teriam que } \\
\text { pagar passagem, ou não comem no RU durante a semana, pois estão no estágio longe dos } \\
\text { RU's. Dessa forma, a alimentação deveria ter a alternativa de receber o dinheiro ou comer no } \\
\text { RU (Estudante 138). }\end{array}$ \\
\hline $\begin{array}{l}\text { Valor } \\
\text { insuficiente } \\
\text { para três } \\
\text { refeições }\end{array}$ & $\begin{array}{l}\text { - O valor é claramente insuficiente para um dia inteiro de alimentação, ele deve ser corrigido } \\
\text { (Estudante } 63 \text { ). } \\
\text { - O valor deveria ser maior, como uma pessoa consegue fazer todas as refeições de um dia } \\
\text { com apenas } R \$ 15,00 \text { ? Acho bem complicado com esse valor (Estudante } 77 \text { ). }\end{array}$ \\
\hline $\begin{array}{c}\text { Elogio a } \\
\text { proposta do } \\
\text { programa }\end{array}$ & $\begin{array}{l}\text { - É um excelente projeto, deveria aumentar o valor dessa bolsa (Estudante 35). } \\
\text { - Muito bom o programa, me auxilia a comer (Estudante 59). }\end{array}$ \\
\hline $\begin{array}{c}\text { Falta de } \\
\text { conhecimento }\end{array}$ & $\begin{array}{l}\text { - Desconhecimento total (Estudante 44). } \\
\text { - Necessita melhor divulgação (Estudante 62) }\end{array}$ \\
\hline $\begin{array}{l}\text { Problemas de } \\
\text { gestão do } \\
\text { programa }\end{array}$ & $\begin{array}{l}\text { - Falta de controle e fiscalização de quem recebe a bolsa acaba gerando um remanejamento } \\
\text { das bolsas para pessoas que não precisam, o que acaba ocasionando uma ação em detrimento } \\
\text { de quem precisa (Estudante 40). } \\
\text { - [...] a incapacidade dos profissionais que trabalham na DDS (no fornecimento de } \\
\text { informações) piora bastante a situação. Visto que muitos não sabem explicar os motivos (do } \\
\text { atraso nos pagamentos) ou nos tratam com ignorância (Estudante 113). }\end{array}$ \\
\hline $\begin{array}{l}\text { Atraso no } \\
\text { pagamento }\end{array}$ & $\begin{array}{l}\text { - [...] o valor é extremamente baixo, atrasa regularmente, e nem todos os meses recebemos } \\
\text { mesmo estudando no campus }[\ldots] \text { (Estudante } 113) . \\
\text { - O auxílio atrasa (Estudante } 123) \text {. }\end{array}$ \\
\hline
\end{tabular}

Os Programas Bolsa Permanência do MEC (PBP/MEC), Acesso à Língua Estrangeira

(PALE) e Auxílio Emergencial (PAE) foram classificados com um grau de importância intermediário, sugerindo uma prioridade secundária em possíveis intervenções para melhoria desses programas, seja em aspectos inerentes a comunição ou a qualidade dos mesmos (Tabela 2).

O Programa Bolsa Permanência do MEC (PBP/MEC) é um programa de pouco conhecimento pelos estudantes, o que limitou a sua capacidade de opinar no questionário aplicado. Esse é um programa que possui os mesmos objetivos do Programa Auxílio Socioeconômico (PASeUnB), além disso, o programa prioriza os indígenas e quilombolas, que, independente da carga horária dos cursos nos quais estão matriculados, poderão receber o $\mathrm{R} \$ 900,00$ (novecentos reais). Fato esse que contribui para explicar o pouco conhecimento do programa e as críticas quanto à dificuldade de conseguir o benefício. 
As principais críticas foram semelhantes às realizadas para o PASeUnB, destacando: valor baixo do benefício e atrasos constantes no pagamento (Figura 5), lembrando que o atual gestor do programa não é o MEC é a UnB.

A Portaria no 389/2013, do Ministério da Educação (MEC) solicitou que as IFES que gerenciassem o PBP/MEC deixassem de utilizar tal nomenclatura, que passaria a ser de uso exclusivo do MEC. O programa advindo dessa Portaria tinha por gerência o próprio MEC. Por meio da Resolução nº 012/2014, do Conselho de Administração da UnB/CAD, o programa bolsa permanência passou a ser denominado de programa auxílio socioeconômico da UnB. Tal Resolução revogou a de $n^{\circ}$ 01/1997. Desta forma, a UnB aderiu ao programa bolsa permanência do MEC (Portaria n ${ }^{\circ}$ 389/2013), bem como instituiu mais um programa de assistência estudantil, o PASeUnB (CAD/UnB, 2014).

Figura 5. Percentual das críticas ou sugestões apontadas pelos estudantes para melhoria do Programa Bolsa Permanência do Ministério da Educação

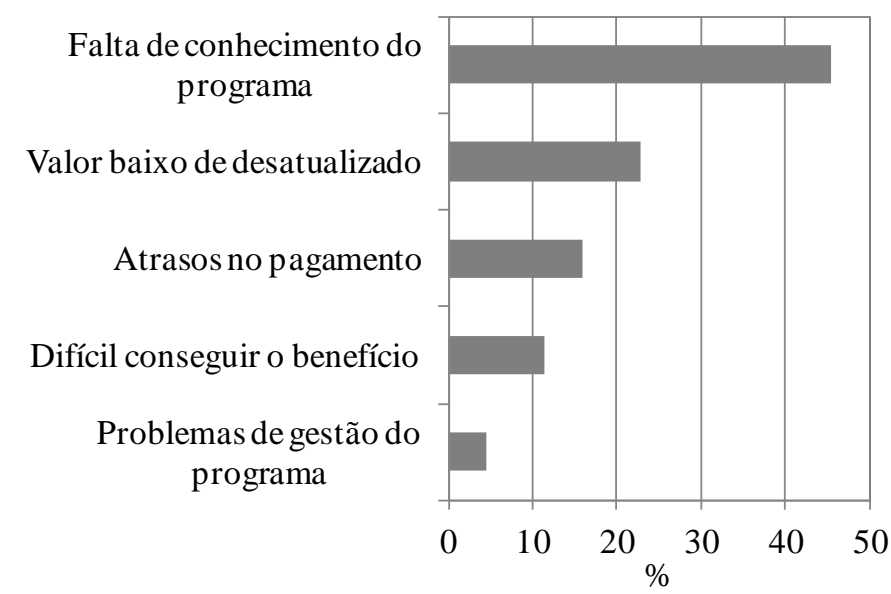

Nota: Número total de sugestões ou críticas para melhoria do PBP/MEC igual a 44.

O Quadro 5 apresentou alguns comentários dos estudantes referentes a críticas e sugestões para melhoria do Programa Bolsa Permanência do Ministério da Educação PBP/MEC. 
Quadro 5. Algumas críticas dos estudantes para melhoria do Programa Bolsa Permanência do Ministério da Educação

\begin{tabular}{|c|l|}
\hline Dimensão & \multicolumn{1}{|c|}{ Críticas ou Sugestões dos Estudantes em Vulnerabilidade Socioeconômica } \\
\hline $\begin{array}{c}\text { Falta de } \\
\text { conhecimento } \\
\text { do programa }\end{array}$ & $\begin{array}{l}\text { - Nunca ouvi falar, não sei se tenho direito. Gostaria de ter mais informações (Estudante 14). } \\
\text { - Sabe-se pouco sobre como conseguir tal benefício (Estudante 45). }\end{array}$ \\
\hline $\begin{array}{c}\text { Valor baixo e } \\
\text { desatualizado }\end{array}$ & $\begin{array}{l}\text { - Acredito que perante os gastos mensais que um estudante possa ter durante a graduação } \\
\text { este valor esteja desatualizado em relação à inflação dos preços (Estudante 38). } \\
\text { - [...] valor inferior ao valor da bolsa permanência pago pela UnB [...] (Estudante 137) }\end{array}$ \\
\hline $\begin{array}{c}\text { Atrasos no } \\
\text { pagamento }\end{array}$ & $\begin{array}{l}\text { - Alta burocracia, e data de recebimento incerta com atrasos frequentes (Estudante 115). } \\
\text { - Valor pequeno (R\$ 400), atrasos e inconstância de datas para o recebimento (Estudante } \\
\text { 138). }\end{array}$ \\
\hline $\begin{array}{c}\text { Difícil } \\
\text { conseguir o } \\
\text { benefício }\end{array}$ & $\begin{array}{l}\text { - Difícil ser contemplado com o programa (Estudante 123). } \\
\text { - Conheço pessoas que necessitam da bolsa, mas nunca conseguiram aprovação para entrar } \\
\text { no programa. Todo mês é a mesma humilhação, ninguém sabe informação de nada } \\
\text { (Estudante 138). }\end{array}$ \\
\hline $\begin{array}{c}\text { Problemas de } \\
\text { gestão do } \\
\text { programa }\end{array}$ & $\begin{array}{l}\text { - Falta de controle e fiscalização de quem recebe a bolsa acaba gerando um remanejamento } \\
\text { das bolsas para pessoas que não precisam, o que acaba ocasionando (Estudante 40). } \\
\text { - Os dados informados no Sistema de Gerenciamento de Bolsas do MEC não correspondem } \\
\text { à realidade. Em geral são divergentes das informações dadas pela Central de Atendimento do } \\
\text { MEC. Isso gera uma série de prejuízos aos estudantes atendidos pela assistência (Estudante } \\
\text { 74). }\end{array}$ \\
\hline
\end{tabular}

O Programa Auxílio Emergencial (PAE) foi pouco reconhecido, provavelmente pelo fato de ele ser disponível apenas para os estudantes em vulnerabilidade socioeconômica e que não se encontram atendidos por outros programas como: Programa Auxílio Socioeconômico (PASeUnB), Programa Moradia Estudantil/Graduação (PME/G) ou Programa Bolsa Permanência do Ministério da Educação (PBP/MEC). Esse fato contribuiu para gerar críticas em relação à limitação do seu acesso, levando os estudantes a perceberem o programa como uma possível ajuda nos casos em que não se é contemplada por outros benefícios e não como um programa de caráter emergencial para atender situações inesperadas (Figura 6). 
Figura 6. Percentual das críticas ou sugestões apontadas pelos estudantes para melhoria do Programa Auxílio Emergencial

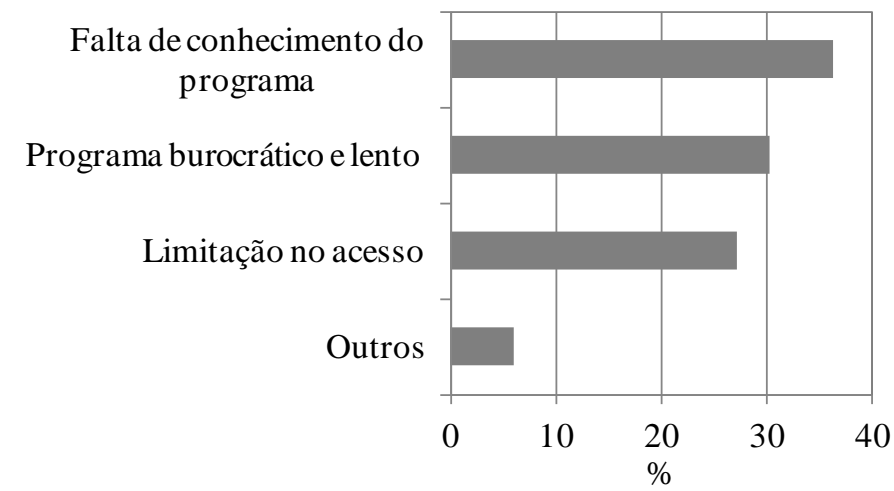

Nota: Número total de sugestões ou críticas para melhoria do PAE igual a 33.

Além das limitações na divulgação e no acesso ao Programa Auxílio Emergencial (PAE), os estudantes entrevistados criticaram a sua burocracia e lentidão, limitando a eficácia do Programa ao atendimento de casos de emergência, os quais, via de regra, demandam uma agilidade de resposta (Quadro 6).

Quadro 6. Algumas críticas dos estudantes para melhoria do Programa Auxílio Emergencial

\begin{tabular}{|c|c|}
\hline Dimensão & Críticas ou Sugestões dos Estudantes em Vulnerabilidade Socioeconômica \\
\hline $\begin{array}{l}\text { Falta de } \\
\text { conhecimento } \\
\text { do programa }\end{array}$ & $\begin{array}{l}\text { - Não é divulgado (Estudante 14). } \\
\text { - Deveria ser melhor divulgado (Estudante 139). }\end{array}$ \\
\hline $\begin{array}{l}\text { Programa } \\
\text { burocrático e } \\
\text { lento }\end{array}$ & $\begin{array}{l}\text { - Muito burocrático e lento ao se tratar de uma emergência (Estudante 20). } \\
\text { - Muita burocracia e muita demora para conseguir este auxilio [...] (Estudante 124). }\end{array}$ \\
\hline $\begin{array}{l}\text { Limitação no } \\
\text { acesso }\end{array}$ & $\begin{array}{l}\text { - Existe uma grande dificuldade de ser atendido por esse programa específico (Aluno 74). } \\
\text { - O que sei desse Auxílio Emergencial, das pessoas que tiveram problemas inesperados que } \\
\text { eu conheço e solicitaram, nenhuma delas conseguiu. Existe mesmo, na prática, este auxílio? } \\
\text { (Estudante 107). }\end{array}$ \\
\hline Outros & $\begin{array}{l}\text { - É muito bom e já fui beneficiada (Estudante 94). } \\
\text { - [...]além do valor também ser muito baixo para um auxílio dito emergencial (Estudante } \\
\text { 124). }\end{array}$ \\
\hline
\end{tabular}

As críticas ao Programa de Acesso à Língua Estrangeira (PALE) se concentraram, quase que exclusivamente, na ampliação e divulgação do programa, denotando a sua grande aceitação na percepção dos estudantes (Figura 7). O descompasso entre a demanda e oferta de vagas para estudantes em vulnerabilidade socioeconômica na Escola de Idiomas da UnB ficou clara nos comentários dos estudantes, constatando relatos de situações humilhantes como, por exemplo, a necessidade de dormir em fila para conseguir o benefício (Quadro 7). 
Figura 7. Percentual das críticas ou sugestões apontadas pelos estudantes para melhoria do Programa de Acesso à Língua Estrangeira

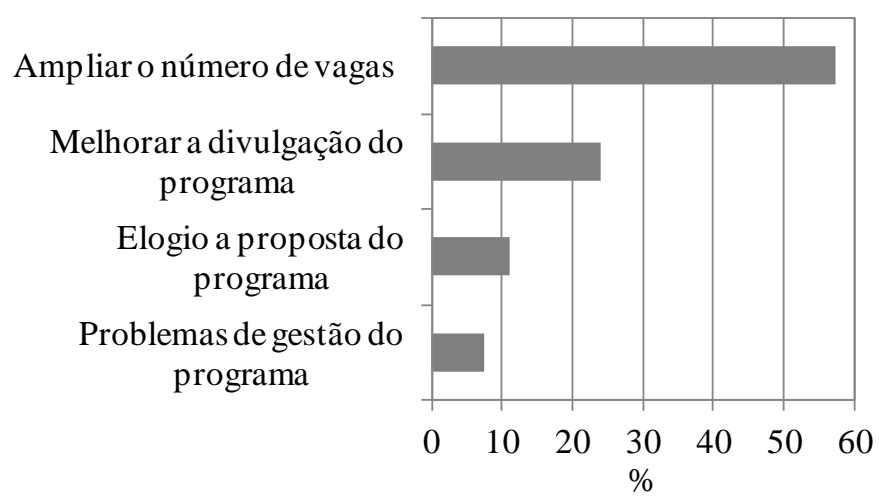

Nota: Número total de sugestões ou críticas para melhoria do PALE igual a 54.

Quadro 7. Algumas críticas dos estudantes para melhoria do Programa de Acesso a Língua Estrangeira

\begin{tabular}{|c|c|}
\hline Dimensão & Críticas ou Sugestões dos Estudantes em Vulnerabilidade Socioeconômica \\
\hline $\begin{array}{l}\text { Ampliar o } \\
\text { número de } \\
\quad \text { vagas }\end{array}$ & $\begin{array}{l}\text { - Pouquíssimas bolsas para estudar no UnB idiomas obrigam os alunos a uma situação } \\
\text { indigna de ficar acampando dois dias antes em frente à Escola de Idiomas para conseguir } \\
\text { vaga (Estudante 58). } \\
\text { - São pouquíssimas vagas, quase impossível conseguir uma, vamos estender esse programa!! } \\
\text { (Estudante 63). }\end{array}$ \\
\hline $\begin{array}{l}\text { Melhorar a } \\
\text { divulgação do } \\
\text { programa }\end{array}$ & $\begin{array}{l}\text { - Pouco divulgado e sem edital ou algo que possa encaminhar o aluno a tentar (Estudante } \\
\text { 92). } \\
\text { - É preciso ter mais divulgação sobre as bolsas do UnB Idiomas e mais bolsas (Estudante } \\
\text { 154). }\end{array}$ \\
\hline $\begin{array}{l}\text { Elogio à } \\
\text { proposta do } \\
\text { programa }\end{array}$ & $\begin{array}{l}\text { - Sou também atendida por esse programa e particularmente o acho excelente [...] (Estudante } \\
\text { 74). } \\
\text { - Muito bom, especialmente para mim que nunca tinha estudado línguas e me ajuda muito } \\
\text { com os trabalhos acadêmicos (Estudante 94). }\end{array}$ \\
\hline $\begin{array}{l}\text { Problemas de } \\
\text { gestão do } \\
\text { programa }\end{array}$ & $\begin{array}{l}\text { - [...] estabelecer critérios claros, horizontais e de acesso universal (Estudante 153). } \\
\text { - A Declaração solicitada, dependia de avaliação socioeconômica, que só foi realizada após a } \\
\text { concessão das bolsas. }\end{array}$ \\
\hline
\end{tabular}

Por fim, o Programa Vale Livro (PVL) foi caracterizado como o de menor importância e entre os programas mais desconhecidos da UnB, acompanhado pelo Programa Bolsa Permanência do Ministério da Educação (PBP/MEC) e o Programa Auxílio Emergência/PAE (Tabela 2). Além da falta de divulgação do Programa Vale Livro (PVL), os estudantes criticaram o baixo desconto oferecido, apenas de 10\%, e a carência de livros necessários nas suas respectivas áreas que são publicados pela Editora da $\mathrm{UnB}$, fatores esses que limitam o aproveitamento do programa (Figura 8). 
Figura 8. Percentual das críticas ou sugestões apontadas pelos estudantes para melhoria do Programa Vale Livros

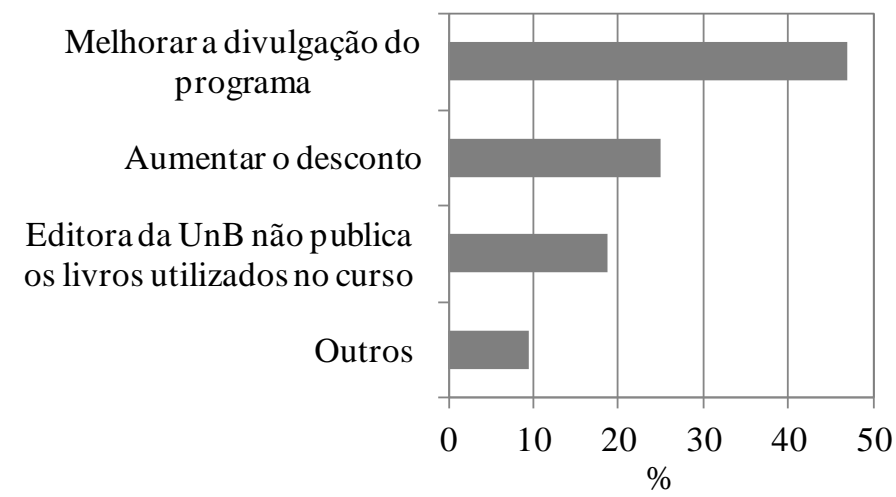

Nota: Número total de sugestões ou críticas para o PVL igual a 32

Alguns comentários em relação ao Programa Vale Livro (PVL) indicaram o pouco uso ou desnecessidade do programa, sendo agrupados na dimensão "outros" da Figura 8. Em geral, esses comentários destacaram a possibilidade de atendimento da necessidade de material pela biblioteca e pelo acesso de livros gratuitos por meio da internet (Quadro 8). Em relação ao uso da biblioteca, uma característica peculiar do aluno em vulnerabilidade socioeconômica é a sua maior permanência e proximidade da UnB, fato esse que facilita a frequência na biblioteca.

Quadro 8. Algumas críticas dos estudantes para melhoria do Programa Vale Livro

\begin{tabular}{|c|c|}
\hline Dimensão & Críticas ou Sugestões dos Estudantes em Vulnerabilidade Socioeconômica \\
\hline $\begin{array}{l}\text { Melhorar a } \\
\text { divulgação do } \\
\text { programa }\end{array}$ & $\begin{array}{l}\text { - Necessita ser melhor divulgado (Estudante 62). } \\
\text { - Divulgar mais o auxílio, através de redes sociais, ou até mesmo da recepção dos calouros } \\
\text { (Estudante 194). }\end{array}$ \\
\hline $\begin{array}{c}\text { Aumentar o } \\
\text { desconto }\end{array}$ & $\begin{array}{l}\text { - Em geral, os livros na Universidade têm um custo alto e o desconto de } 10 \% \text { dado pelo vale } \\
\text { livro é muito baixo. Logo, não possibilita que estudantes da assistência adquiram livros } \\
\text { (Estudante } 74 \text { ). } \\
\text { - } 10 \% \text { de desconto é tão pouco que creio que quem pensou neste auxilio pensou nele como } \\
\text { um auxílio apenas simbólico (Estudante 124). }\end{array}$ \\
\hline $\begin{array}{l}\text { Editora da UnB } \\
\text { não publica os } \\
\text { livros utilizados } \\
\text { no curso }\end{array}$ & $\begin{array}{l}\text { - Praticamente não tem livros da Editora UnB para minha área e os poucos que têm não são } \\
\text { utilizados como bibliografia do meu curso. Seria mais útil um vale-livro de outras livrarias } \\
\text { (Estudante 14). } \\
\text { - Ter disponibilidade de livros que realmente atendam as nossas necessidades (Estudante 47). }\end{array}$ \\
\hline Outros & $\begin{array}{l}\text { - Acho que talvez as pessoas que utilizem gostem. Prefiro me abster, já que não utilizo. } \\
\text { Baixo todos os livros pela internet, e se não achar de graça, compro na Cultura em formato } \\
\text { E-Book (Estudante 107). } \\
\text { - Ainda não usei (Estudante 191). }\end{array}$ \\
\hline
\end{tabular}




\subsection{Avaliação do Restaurante Universitário}

Em geral, os RUs da UnB foram bem avaliados pelos estudantes em vulnerabilidade socioeconômica, apenas a qualidade do suco (QS) e a variedade do cardápio (VC) não foram bem classificadas nos restaurantes analisados. Algumas diferenças entre os resultados da avaliação do RU do campus Darcy Ribeiro com os dos campi de Planaltina, Ceilândia e Gama foram identificadas, destacando uma carência na agilidade do atendimento (AAt) apenas no RU do campus Darcy Ribeiro e problemas com a qualidade dos alimentos (QA) e tamanho do refeitório (TR) apenas nos RUs dos campi de Ceilândia, Gama e Planaltina (Figura 9 e Tabela 3).

Provavelmente, as críticas na agilidade do atendimento no RU do campus Darcy Ribeiro se devem a sua maior fila, explicado pela consolidação desse campus e ao grande número de refeições servidas. Por outro lado, a percepção quanto à qualidade inferior dos alimentos nos campi de Ceilândia, Gama e Planaltina pode ser explicada pela recente inauguração desses restaurantes e, possivelmente, uma menor consolidação nos seus processos internos. 
Figura 9. Avaliação da qualidade de diversos aspectos dos RUs da UnB
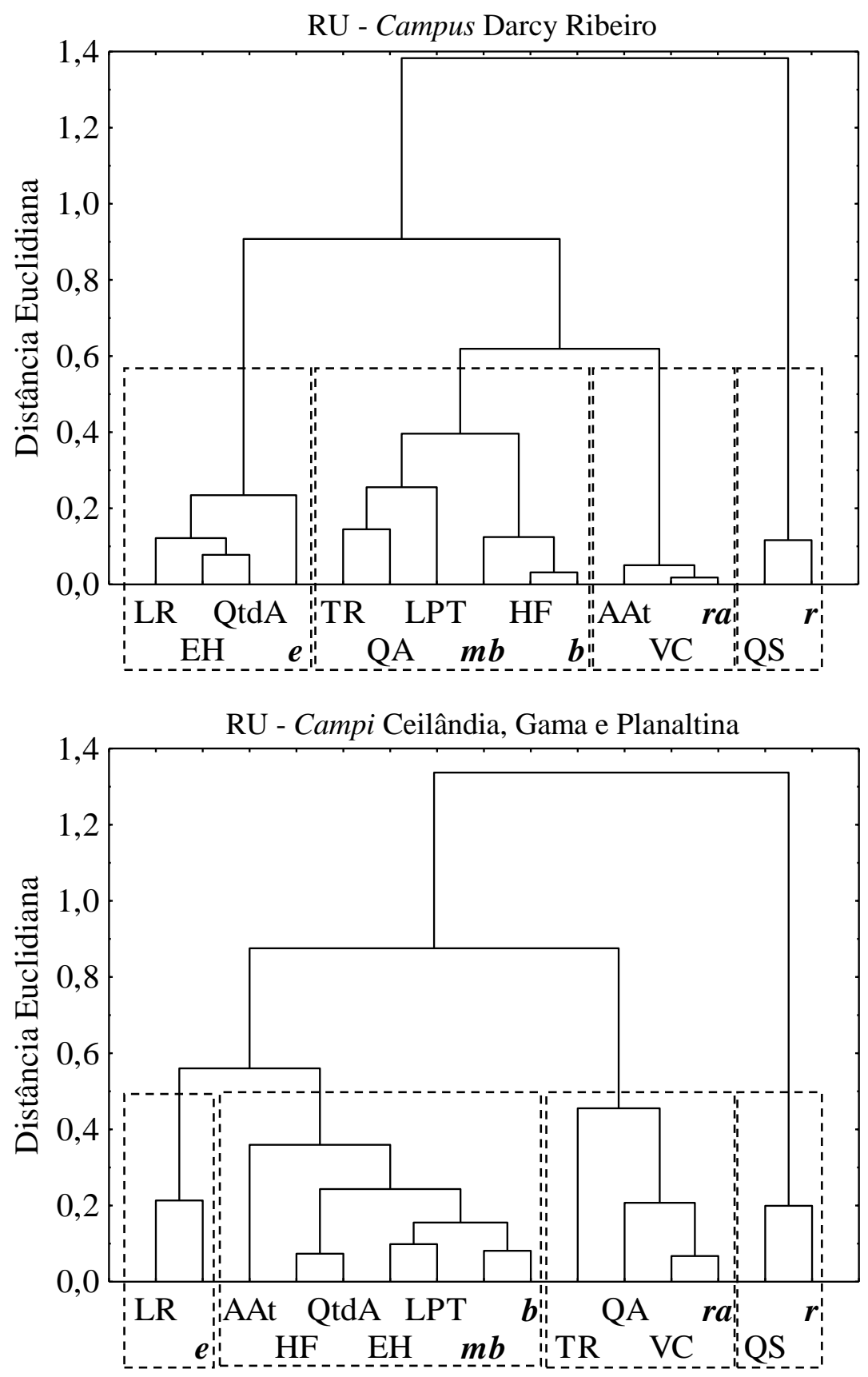

Nota: AAt - agilidade no atendimento; LPT - limpeza dos pratos e talheres; QtdA - quantidade do alimento servido; QA - qualidade do alimento; QS - qualidade do suco; VC - variedade no cardápio; LR - limpeza do refeitório; TR - tamanho do refeitório; EH - espaços para higiene das mãos e banheiros; HF - horário de funcionamento; $\boldsymbol{e}$ - excelente; $\boldsymbol{m} \boldsymbol{b}$ - muito bom; $\boldsymbol{b}$ - bom; $\boldsymbol{r} \boldsymbol{a}$ - razoável; $\boldsymbol{r}$ - ruim. 
Aspectos relacionados com a higiene, seja na limpeza do refeitório (LR) ou dos pratos e dos talheres (LPT), bem como, na disposição de espaços adequados para higienização pessoal (EH), apresentaram-se positivamente para todos os RUs. Questões inerentes a quantidade de alimento servido (QtdA) e ao horário de funcionamento (HF) dos restaurantes também se identificaram como adequados na opinião da maioria dos alunos entrevistados (Tabela 3).

Tabela 3. Resumo dos resultados da avaliação dos RUs da UnB

\begin{tabular}{ccc}
\hline & Campus do Darcy Ribeiro & Campi de Ceilândia, Gama e Planaltina \\
\hline Excelente & LR, EH e QtdA & LR \\
Bom ou Muito Bom & TR, QA, LPT e HF & AAt, HF, QtdA, EH e LPT \\
Razoável & AAt e VC & TR, QA e VC \\
Ruim & QS & QS \\
\hline
\end{tabular}

Nota: AAt - agilidade no atendimento; LPT - limpeza dos pratos e talheres; QtdA - quantidade do alimento servido; QA - qualidade do alimento; QS - qualidade do suco; VC - variedade no cardápio; LR - limpeza do refeitório; TR - tamanho do refeitório; EH - espaços para higiene das mãos e banheiros; HF - horário de funcionamento.

Da amostra pesquisada, composta de 112 estudantes que utilizam o RU do campus Darcy Ribeiro e 77 dos campi de Ceilândia, Gama e Planaltina, em torno de $30 \%$ dos respondentes fizeram alguma sugestão de melhoria no espaço aberto do questionário. Embora esses comentários não representem a maioria dos estudantes entrevistados, a sua observação trouxe elementos importantes para uma possível tomada de decisão, pois evidenciou fatores decisivos para o uso dos RUs por um grupo maior de estudantes. Nesse aspecto, destacaramse as sugestões para a ampliação do horário de funcionamento do restaurante no jantar e, principalmente, no período do café da manha (Figura 10). Atualmente, o horário de funcionamento dos RUs do campus Darcy Ribeiro e dos campi de Ceilândia, Gama e Planaltina são: café da manhã, das $7 \mathrm{~h}$ às $9 \mathrm{~h}$; almoço, das $11 \mathrm{~h}$ às $14 \mathrm{~h} 30$; e jantar, das $17 \mathrm{~h}$ às 19h30.

Como pode ser visto na Figura 10, destacaram-se críticas quanto à variedade do cardápio e também na qualidade da refeição, destacando propostas para a ampliação da variedade de carnes e pratos vegetarianos, bem como, sugestões de melhorias no preparo e 
limpeza dos alimentos. Especificamente para o RU do campus de Planaltina, algumas críticas quanto à higiene da comida foram encontradas e dois estudantes relataram já terem encontrados insetos na comida, sendo esse assunto divulgado em redes sociais.

Situação semelhante à ocorrida no RU de Planaltina aconteceu nas Universidades Federais da Paraíba (UFPB) e de Roraima (UFRR), onde estudantes usaram as redes sociais para reclamar da qualidade da comida servida, mostrando fotos de larvas e insetos dentro de pratos de sopa que, segundo os alunos, foram servidos no jantar (ALVES, 2016; DCE/UFRR 2016).

Figura 10. Percentual das críticas ou sugestões dos alunos para melhoria dos RUs da UnB

\section{RU do Campus Darcy Ribeiro}

Ampliar horário de funcionamento, principalmente no cafée jantar

Falta de diversificação do cardápio Problemas com a qualidade da comida, decorrente do seu preparo

Demora na fila

Ampliar tamanho do restaurante

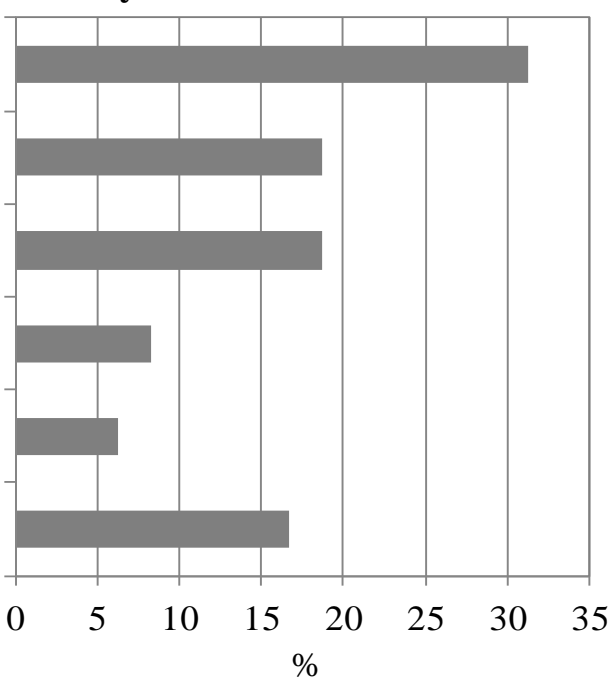

RUs dos Campi de Ceilândia, Gama e Planaltina

Ampliar horário de funcionamento, principalmente no café da manhã

Problemas com a qualidade da comida devido ao seu preparo e higiene

Melhorar infraestrutura contra chuvae incluir mais mesas

Diversificar cardápio

Falta de qualidade do suco

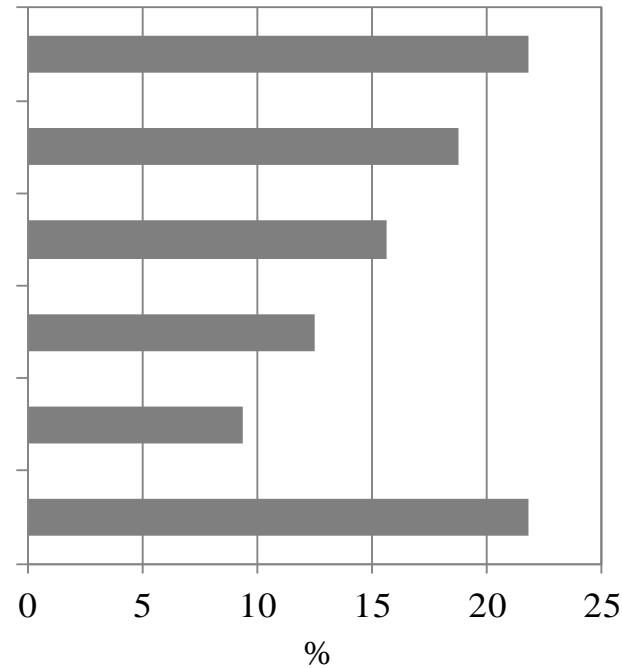

Nota: Número total de sugestões ou críticas para melhoria dos RUs da UnB: 48 para o RU do campus Darcy Ribeiro e 32 para os RUs dos campi de Ceilândia, Gama e Planaltina. 
Outro aspecto importante, e não detectado na pesquisa quantitativa, foram problemas específicos em relação à infraestrutura dos RUs nos campi de Ceilândia, Gama e Planaltina, especialmente no que tange a sua proteção contra intempéries (Figura 10). Nos RUs dos campi de Ceilândia e Gama foram registrados dois comentários sugerindo uma ampliação no número de mesas. Alguns comentários representativos foram apresentados no Quadro 9.

Quadro 9. Algumas críticas dos estudantes em vulnerabilidade socioeconômica para melhoria dos RUs

\begin{tabular}{|c|c|}
\hline \multicolumn{2}{|r|}{ RU do campus Darcy Ribeiro } \\
\hline $\begin{array}{l}\text { Ampliar horário de funcionamento, } \\
\text { principalmente no café e jantar }\end{array}$ & $\begin{array}{l}\text { - Aumentar o horário de café da manhã e jantar. Fecha relativamente } \\
\text { cedo nesses períodos (Estudante 11). }\end{array}$ \\
\hline Falta de diversificação do cardápio & - Poderia ter mais opções de frutas e saladas (Estudante 58). \\
\hline $\begin{array}{l}\text { Problemas com a qualidade da comida } \\
\text { decorrente do seu preparo }\end{array}$ & $\begin{array}{l}\text { - A comida não é sempre bem preparada, isso gera muito desperdício, } \\
\text { pois não há como ingerir carnes cruas ou mal preparadas (Estudante } \\
\text { 105). }\end{array}$ \\
\hline Demora na fila & $\begin{array}{l}\text { - Acho que deveria ter um melhor planejamento para evitar as filas. } \\
\text { (Estudante 4). }\end{array}$ \\
\hline Ampliar tamanho do restaurante & $\begin{array}{l}\text { - A ampliação do restaurante se faz necessária mediante o número de } \\
\text { estudantes que o utilizam (Estudante 8). }\end{array}$ \\
\hline Outros & $\begin{array}{l}-[\ldots] \text { melhoria das condições de trabalho dos funcionários, } \\
\text { desterceirizar [...] (Estudante 77). }\end{array}$ \\
\hline \multicolumn{2}{|c|}{ RUs dos campi de Ceilândia, Gama e Planaltina } \\
\hline $\begin{array}{l}\text { Ampliar horário de funcionamento, } \\
\text { principalmente no café da manhã }\end{array}$ & $\begin{array}{l}\text { - Podia estender o prazo do café da manhã para até 9h30 (Estudante } \\
\text { 169) }\end{array}$ \\
\hline $\begin{array}{l}\text { Problemas com a qualidade da comida } \\
\text { devido ao seu preparo e higiene }\end{array}$ & - Melhorar a limpeza das verduras (Estudante 149) \\
\hline $\begin{array}{l}\text { Melhorar infraestrutura contra chuvas } \\
\text { e incluir mais mesas }\end{array}$ & $\begin{array}{l}\text { - [...] temos sérios problemas, como a infraestrutura do local, quando } \\
\text { chove, dias de ventania, frios ou com neblina não temos como nos } \\
\text { proteger }[\ldots] \text { (Estudante 177). }\end{array}$ \\
\hline Diversificar cardápio & - Aumentar as opções de carne e verduras (Estudante 158) \\
\hline Falta de qualidade do suco & - Trocar suco artificial por sucos naturais (Estudante 118). \\
\hline Outros & $\begin{array}{l}\text { - Preparo dos alimentos de origem orgânica e da agricultura familiar } \\
\text { [...] (Estudante 121). }\end{array}$ \\
\hline
\end{tabular}

\subsection{Avaliação da Casa do Estudante Universitário (CEU)}

Conforme a percepção dos estudantes em vulnerabilidade socioeconômica que se consideraram em condições de avaliar a Casa do Estudante Universitário (CEU), os principais problemas decorrem da disponibilidade e qualidade de serviços relacionados à limpeza, segurança, iluminação, internet, água, luz, telefone, entre outros. Enquanto aspectos inerentes à disponibilidade e qualidade dos serviços na CEU foram percebidos como razoáveis, a 
infraestrutura e a convivência entre os estudantes foram classificadas como muito boa e excelente, respectivamente (Figura 11).

Figura 11. Avaliação da infraestrutura, serviço e convivência entre os estudantes na CEU

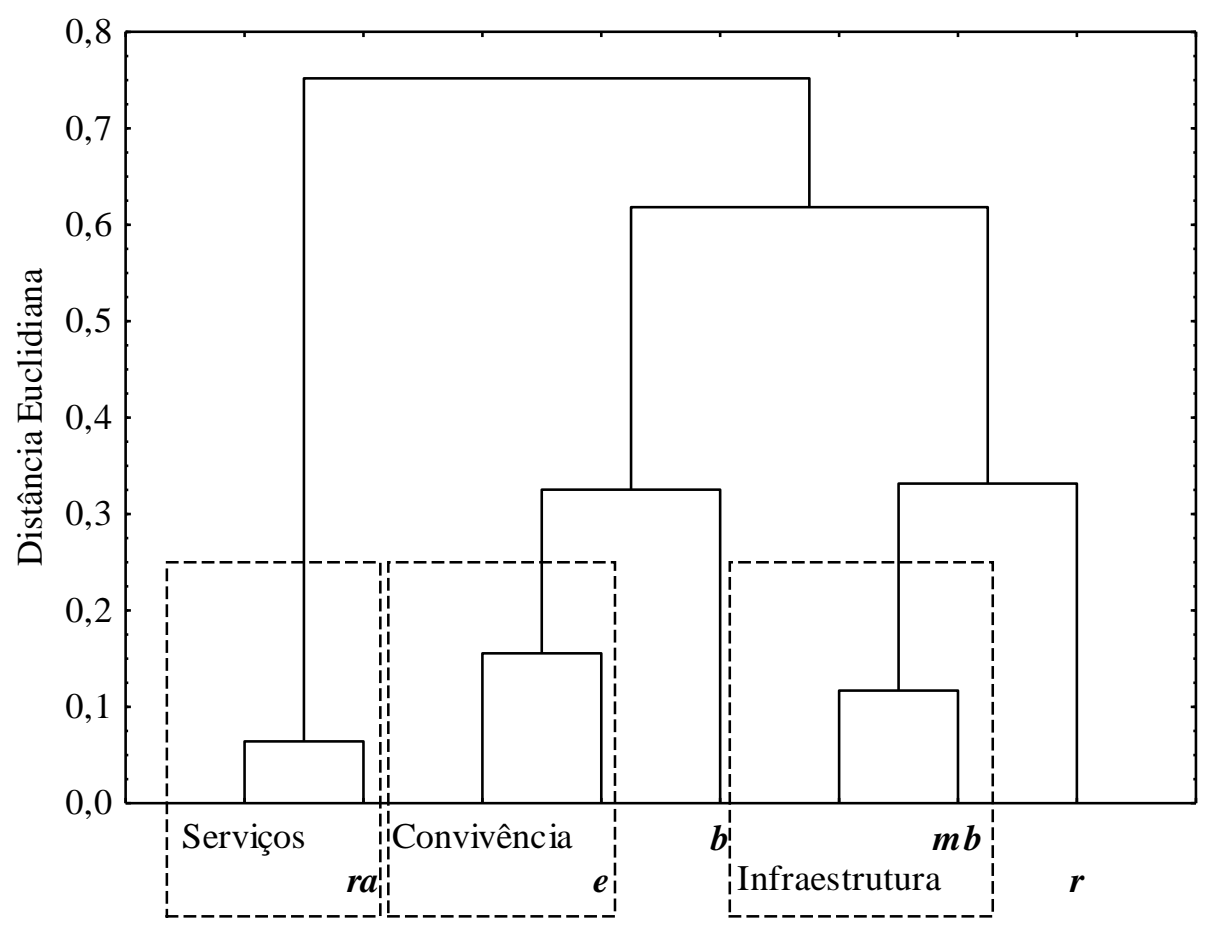

Nota: $\boldsymbol{e}$ - excelente; $\boldsymbol{m} \boldsymbol{b}$ - muito bom; $\boldsymbol{b}$ - bom; $\boldsymbol{r} \boldsymbol{~ - ~ r a z o a ́ v e l ; ~} \boldsymbol{r}$ - ruim.

As opiniões abertas no questionário corroboraram os resultados da Figura 11 e contribuíram para o seu entendimento. Por meio da análise do conteúdo dos comentários dos estudantes, constatou-se que o principal problema da CEU se deve a limitações na disponibilidade e velocidade da internet. Em segundo lugar destacaram-se problemas com a falta de água e, na opinião de dois estudantes, a iluminação e a segurança da CEU também carecem de melhorias. Problemas de falta de luz, indisponibilidade do elevador, interfone estragado e ao fechamento da sala de estudantes durante o período noturno foram apontados por apenas um estudante, esses foram agregados na dimensão de "outros" na Figura 12. 
Figura 12. Percentual das críticas ou sugestões apontadas pelos estudantes em vulnerabilidade socioeconômica para melhoria dos serviços prestados na CEU

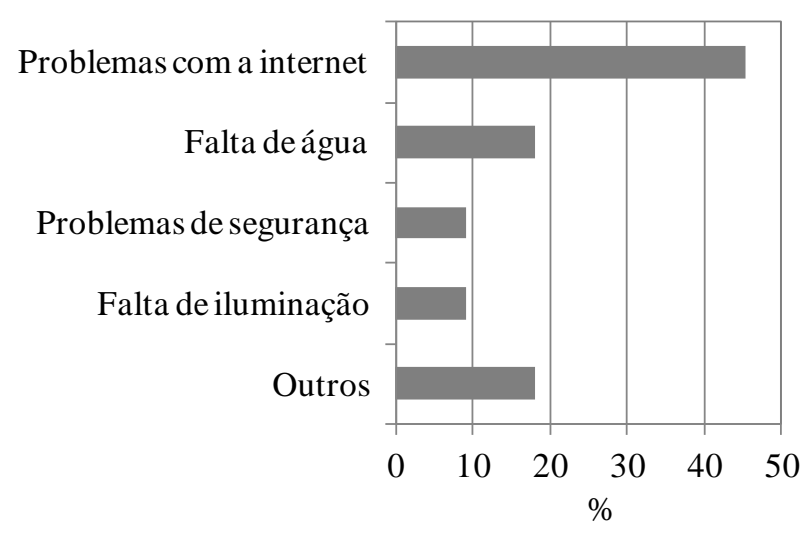

Nota: Número total de sugestões ou críticas para melhoria dos serviços prestados na CEU igual a 22.

Alguns comentários dos estudantes a respeito dos problemas na qualidade dos serviços disponíveis na CEU foram apresentados no Quadro 10. A avaliação do conteúdo das respostas permitiu identificar situações constrangedoras como, por exemplo, a necessidade de subir pelas escadas com baldes de água para dar descarga no banheiro. O funcionamento dos elevadores também foi outro ponto de reclamação levantado pelos universitários. Os estudantes afirmaram que esses equipamentos só são ligados em caso de emergência.

Quadro 10. Algumas críticas dos estudantes em vulnerabilidade socioeconômica para melhoria dos serviços prestados na CEU

\begin{tabular}{|c|l|}
\hline $\begin{array}{c}\text { Problemas com a } \\
\text { internet }\end{array}$ & - A Internet não funciona aos fins de semana e cai todo momento (Estudante 88). \\
\hline Falta de água & $\begin{array}{l}\text { - Às vezes, sofremos com a falta de água e falta de internet que chegamaá durar uma } \\
\text { semana, dessa forma ficamos impossibilitados de fazer nossos trabalhos, e ainda quando } \\
\text { há falta água temos que ficar carregando baldes de água utilizando a escada, uma vez que } \\
\text { tem elevadores que funcionam mas não são liberados para os alunos (Estudante 46). }\end{array}$ \\
\hline $\begin{array}{c}\text { Problemas de } \\
\text { segurança }\end{array}$ & $-[\ldots]$ a segurança não é para os alunos é para vigiá-los (Estudante 139). \\
\hline Falta de iluminação & - Iluminação péssima [...] (Estudante 169). \\
\hline Outros & $\begin{array}{l}\text { - Bom, só acho que a sala de estudantes deveria ficar aberta, pois estudo muito à noite } \\
\text { (Estudante 93). }\end{array}$ \\
\hline
\end{tabular}

Embora a infraestrutura da CEU tenha sido classificada como muito boa; alguns problemas específicos foram identificados nas respostas abertas dos entrevistados. Os problemas apontados puderam ser agrupados em quatro dimensões: 1) problemas de conserto; 
2) problemas arquitetônicos; 3) problemas de localização e 4) falta de servidores para resolver problemas diversos na CEU (Figura 13).

Figura 13. Percentual das críticas ou sugestões apontadas pelos estudantes para melhoria da infraestrutura da CEU

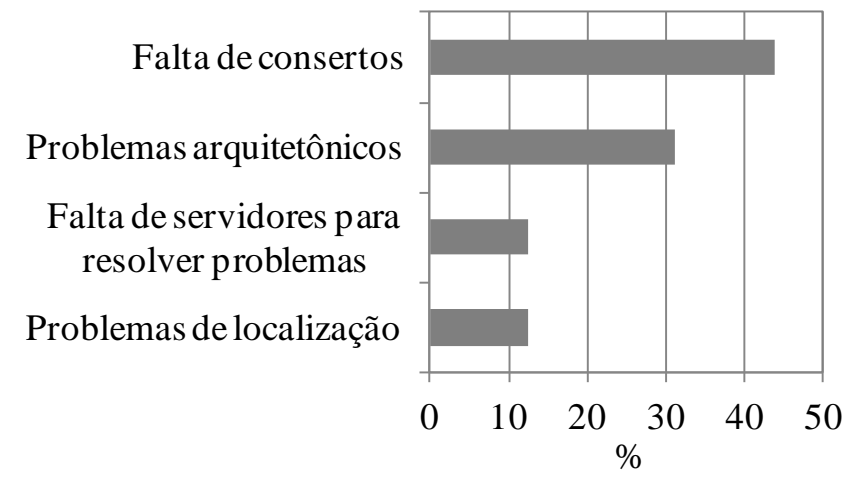

Nota: Número total de sugestões ou críticas para melhoria da infraestrutura da CEU igual a 16

O maior número de críticas se referiu aos problemas de falta de conserto (Figura 13). Os problemas de falta de conserto englobaram, principalmente, críticas quanto à presença de mofo nas paredes e chuveiros queimados. Outros problemas dessa natureza citados foram: vidros e portas quebrados, piso descolando, lâmpadas queimadas, problemas com a descarga do vaso sanitário, maçanetas que se soltam facilmente, infiltrações, entre outros.

No rol de queixas, o mofo é um item constante. Sem ventilação, os cômodos que abrigam o banheiro frequentemente apresentam acúmulo de fungos. Entre os universitários entrevistados, alguns ainda citaram que desenvolveram alergia por causa desse problema.

Os problemas de falta de reparos na CEU são preocupantes, principalmente tendo em vista que a CEU passou por uma ampla reforma nos últimos anos. A UnB investiu R\$ 9 milhões em melhorias nos 90 apartamentos dos dois prédios da CEU, onde, atualmente, moram 280 alunos (SECOM/UnB, 2014). As obras, iniciadas em 2011, foram concluídas em setembro de 2014, com inauguração oficial três meses depois. Pouco mais de um ano após a intervenção, vários problemas já são detectados, sugerindo uma baixa relação benefício/custo da reforma no longo prazo. 
Outro conjunto de críticas pôde ser agrupado dentro de um grupo de problemas arquitetônicos da CEU (Figura 13). Os principais problemas arquitetônicos foram a falta de porta nos quartos e de janela no banheiro. Paiva e Mendes (2001), em análise da CEU da UnB, criticaram a falta de delimitação física clara nos espaços dos dormitórios, alegando um comprometimento da privacidade (essa falta de privacidade, perdura em 2015, conforme relatos dos estudantes, moradores da CEU/UnB) o que contribui para a deterioração das relações interpessoais entre os estudantes. Já a falta de janela ou ventilação no banheiro contribui para explicar a grande quantidade de críticas aos mofos nas paredes.

Além da falta de porta nos quartos e janela nos banheiros, outros problemas arquitetônicos relatados foram: dificuldades de limpeza de casa de insetos no teto, pois esse é muito alto; falta de espaço para privacidade; problemas de acústica; varal que não seca a roupa; entre outros.

Em menor quantidade, identificaram-se alguns comentários relatando a baixa disponibilidade de servidores para resolução de problemas ou pequenos reparos na CEU, bem como, críticas quanto à distância da CEU para a UnB. Um resumo dos comentários dos alunos foi apresentado no Quadro 11.

Quadro 11. Algumas críticas dos estudantes em vulnerabilidade socioeconômica para melhoria da infraestrutura da CEU

\begin{tabular}{|c|l|}
\hline Falta de consertos & $\begin{array}{l}\text { - [...] a casa está repleta de problemas como mofo, chuveiro quebrado, } \\
\text { equipamentos como fechaduras e trincos que quebram em um ano, piso de plástico, } \\
\text { etc. (Estudante 57). }\end{array}$ \\
\hline $\begin{array}{c}\text { Problemas } \\
\text { arquitetônicos }\end{array}$ & $\begin{array}{l}\text { - Teto muito alto sem possibilidade de retirar moradia de insetos que sujam a casa, } \\
\text { falta e janela no banheiro (Estudante 88). }\end{array}$ \\
\hline $\begin{array}{c}\text { Falta de servidores para } \\
\text { resolver problemas }\end{array}$ & - Faltam servidores para atendimento aos problemas da CEU (Estudante 118). \\
\hline $\begin{array}{c}\text { Problemas de } \\
\text { localização }\end{array}$ & $\begin{array}{l}\text { - O local é um pouco distante, portanto deveria haver mais meios de transporte até a } \\
\text { Universidade (Estudante 141). }\end{array}$ \\
\hline
\end{tabular}

A convivência entre os estudantes na CEU foi caracterizada como excelente e os raros problemas relatados corroboram essa harmonia. No aspecto convivência, apenas seis problemas foram relatados e, quatro deles, se referiram a críticas para a DDS em relação à 
falta de apoio para melhorar o relacionamento entre os estudantes ou a dificuldade imposta para o recebimento de visitas, conforme comentário de um estudante:

Por conta da falta de programas de convivência entre os moradores, não existe nenhum tipo de ação proposta pela a universidade no sentido de trabalhar a questão comunitária na Casa do Estudante, além da universidade reprimir qualquer forma de convivência entre os moradores (comemoração de aniversários, reunião de amigos, recepção de visitas para per noite). Não existe na Casa do Estudante Universitário um espaço de convivência entre os estudantes, seja para fazer um churrasco, ou espaços para conversar etc. (estudante 65).

Naturalmente, sugestões para ampliar a boa convivência e integração entre os estudantes são positivas, desde que não ultrapassem regras estabelecidas e atrapalhem o seu desenvolvimento acadêmico. Talvez, devido às restrições de convivência na CEU, apenas um relato sobre problemas com barulho foi registrado. Nesse aspecto, destaca-se o impacto da sonolência de alunos no ensino superior (ARAUJO \& ALMODES, 2012), chegando a validações empíricas que mostram uma associação significativa entre sonolência excessiva com baixo rendimento acadêmico (MORALES et al., 2005).

Outro problema que pode acarretar prejuízos psicológicos e acarretar redução de desempenho acadêmico são os relacionados à discriminação, problema esse apontado apenas por um estudante e aparentemente pouco importante dentro da CEU.

Além de poucos problemas terem sido relatados, destacaram-se alguns elogios e depoimentos que corroboram a excelente convivência dos estudantes na CEU como, por exemplo:

Os colegas estudantes da CEU são como uma família que eu não tive. O companheirismo e solidariedade dos colegas facilita o desenvolvimento acadêmico (Estudante 57).

Zancul e Fabrício (2008), em trabalho sobre a habitação estudantil na cidade de São Carlos, analisaram as principais inadequações no atendimento às necessidades habitacionais dos estudantes. Na avaliação dos autores, destacaram-se os problemas relacionados aos seguintes aspectos: áreas de serviço destinadas à higienização de roupas; áreas destinadas ao lazer; áreas de estacionamento; dimensionamento de instalações elétricas e lógicas para 
computadores e acesso à internet; espaço e mobiliário adequados para as atividades de estudo e leitura.

Vilela Júnior (2003) realizou uma pesquisa qualitativa e entrevistou moradores de diversas moradias estudantis, além de arquitetos que projetaram alguns dos edifícios escolhidos. O autor concluiu que os projetos desse tipo de edificação precisam avançar em três questões básicas: (1) a do convívio social, com áreas que promovam a necessária integração dos moradores; (2) a dos serviços, incluindo estrutura para atividades domésticas; e (3) a dos espaços específicos, com a implantação de áreas que supram a necessidade extraclasse dos moradores, como laboratórios, estúdios e ateliês.

\subsection{Desempenho Acadêmico e Dificuldades Peculiares dos Estudantes em}

\section{Vulnerabilidade Socioeconômica.}

Os resultados em relação ao desempenho acadêmico dos estudantes em vulnerabilidade socioeconômica não indicaram um pior desempenho desse grupo de estudantes. Pois, conforme a percepção dos entrevistados, quase metade dos estudantes em vulnerabilidade socioeconômica afirmaram estar entre os $20 \%$ dos estudantes com melhor desempenho e apenas $16 \%$ afirmaram estar entre os de pior desempenho em seus respectivos cursos (Figura 14).

Figura 14. Desempenho acadêmico dos Estudantes em Vulnerabilidade Socioeconômica

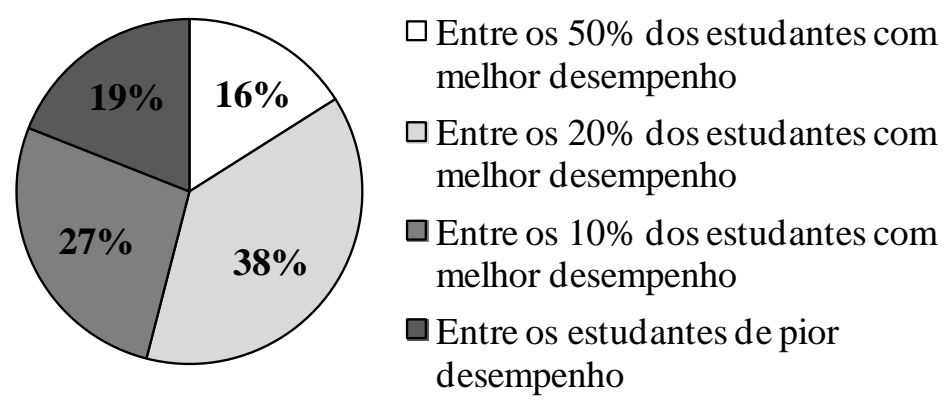

Os resultados da pesquisa de Dallanona e Schielfer (2011) corroboraram os resultados.

Os autores buscaram comparar o rendimento entre estudantes vindos de escola pública e, 
portanto, que ingressaram via sistema de cotas com o desempenho dos estudantes não cotistas na Universidade Federal Tecnológica do Paraná (UTFPR). Os resultados indicaram que as diferenças entre o desempenho dos cotistas e não cotistas foram muito baixas, sendo que os cotistas têm pequena vantagem nos cursos de licenciatura e média um pouco inferior nos bacharelados e tecnologias.

Com resultados equiparáveis aos de Dallamona e Schielfer (2011), Queiroz e Santos (2006) identificaram que estudantes cotistas e, provavelmente, em condições de vulnerabilidade socioeconômica, obtiveram coeficientes de rendimento iguais ou melhores ao dos não-cotistas em onze de dezoito cursos de maior concorrência avaliados da Universidade Federal da Bahia (UFBA).

Apenas uma minoria dos estudantes em vulnerabilidade socioeconômica declarou exercer alguma atividade remunerada fora do expediente do curso (Figura 15). Basicamente, esses resultados podem ser interpretados de duas formas: 1) sugerem uma dificuldade dos estudantes encontrarem emprego e conciliarem com os estudos ou 2) a assistência estudantil minimiza maiores problemas financeiros dos estudantes em vulnerabilidade socioeconômica. 
Figura 15. Possíveis dificuldades enfrentadas pelos estudantes em vulnerabilidade socioeconômica

Você trabalha ou exerce alguma atividade remunerada fora do expediente do curso?

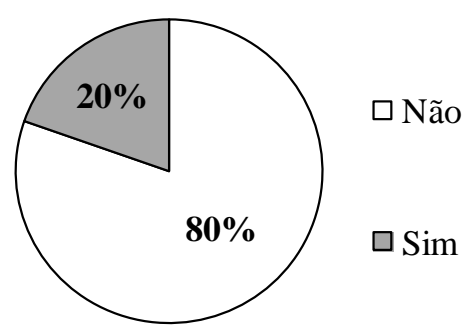

Os estudantes em vulnerabilidade socioeconômica possuem maiores dificuldades nas disciplinas devido à pior formação no ensino médio.

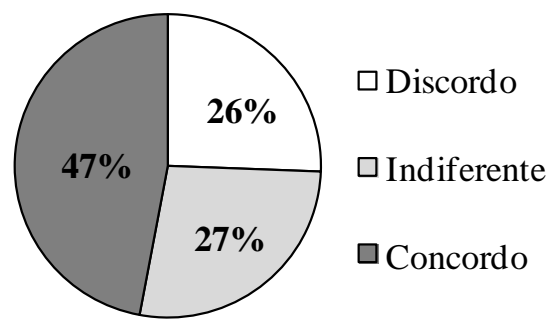

Os programas de assistência estudantil não são suficientes para suprir as necessidades dos estudantes em vulnerabilidade socioeconômica.

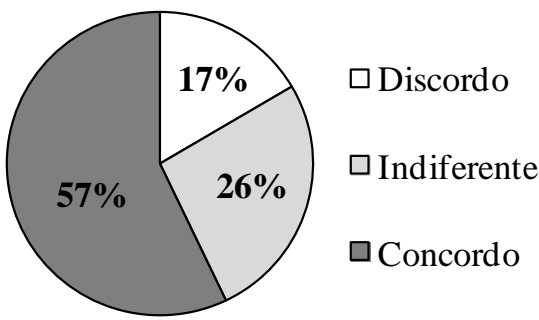

O estudante beneficiado pelos programas de assistência estudantil sofre assédio moral acima do normal.

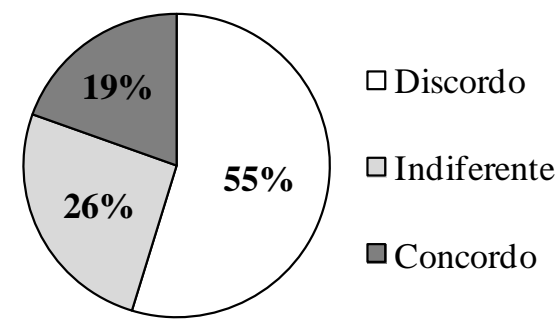

A maioria dos estudantes entrevistados, cerca de $80 \%$, cursa algum curso no período diurno e, portanto, com uma maior dificuldade de ingressarem no mercado de trabalho. Porém, é possível que parte de seus problemas financeiros sejam minimizados em decorrência da obtenção de recursos por meio de projetos de iniciação científica, extensão ou estágios acadêmicos remunerados.

Cerca de $40 \%$ dos estudantes entrevistados declararam participar ou já terem participado de algum projeto remunerado de iniciação científica, extensão ou estágio acadêmico. Somando os valores recebidos nessas atividades com os obtidos de monitorias em disciplinas, o ganho médio por estudante em vulnerabilidade socioeconômica decorrente somente de atividades acadêmicas no mês de outubro de 2015 foi de $\mathrm{R} \$ 323,54$ por mês.

Caso o estudante em vulnerabilidade socioeconômica consiga participar de um projeto de iniciação científica remunerado ou similar (bolsa de $\mathrm{R} \$ 400,00$ ), receba o PASeUnB ( $\mathrm{R} \$$ 
465,00), seja de fora de Brasília e consiga o auxílio moradia ( $\mathrm{R} \$ 530,00)$, o seu rendimento alcança R \$ 1.395,00 para arcar com os seus custos de vida. Dado a gratuidade do RU, o principal custo desse aluno é com aluguel e esse gira em torno de $\mathrm{R} \$ 900,00$ para uma quitinete perto do campus Darcy Ribeiro da UnB, sobrando cerca de R\$500,00 para o restante das contas: água, luz, telefone, material escolar, diversão, alimentação e transporte. Se considerarmos que quase metade da população brasileira sobrevive com um salário mínimo (R\$ 788,00 em 2015) e não possui o benefício da alimentação gratuita (IBGE, 2016), não parece justo falar em sacrifício sobreviver com os programas da assistência estudantil e outras oportunidades proporcionadas pela UnB, porém, tal como a parte da população que sobrevive com um salário mínimo, sem dúvidas, a vida do estudante em vulnerabilidade socioeconômica não é fácil.

Conforme a maioria dos estudantes em vulnerabilidade socioeconômica, os programas de assistência estudantil não são suficientes para o suprimento de suas necessidades, apenas 17\% dos estudantes discordaram dessa afirmação (Figura 15). Além disso, quase metade dos entrevistados afirmou que a formação insuficiente no ensino médio é um entrave para acompanhamento das disciplinas e apenas $19 \%$ das respostas concordaram que problemas de assédio moral é maior com os estudantes, minimizando esse problema.

\subsection{Impacto das Dificuldades do Estudante em Vulnerabilidade Socioeconômica no seu}

\section{Desempenho Acadêmico}

O impacto das dificuldades enfrentadas pelos estudantes em vulnerabilidade socioeconômica no seu desempenho acadêmico e os indicadores estatísticos do modelo de regressão ajustado foi apresentado na Equação [3].

$\mathrm{DA}=3,38-0,33 \mathrm{SA}-0,09 \mathrm{IPAE}-0,16 \mathrm{FIAD}+0,04 \mathrm{SAM}$

$\begin{array}{lrrrrr}t & 11,03 & -1,69 & -1,27 & -2,51 & 0,68 \\ \text { Sig. } & 0,01 & 0,05 & 0,10 & 0,01 & 0,25\end{array}$


$\begin{array}{lllll}\text { FIV } & 1,01 & 1,25 & 1,09 & 1,21\end{array}$

$\mathrm{n}=189 \quad \mathrm{R}^{2}$ ajustado $=0,05 \quad \mathrm{~F}=2,97 \quad d=2,02$

Nota: DA - desempenho acadêmico; SA - situação atual (trabalhando ou não); IPAE - insuficiência dos programas de assistência estudantil; FIAD - formação insuficiente no ensino médio para acompanhar as disciplinas; SAM - sofrimento com assédio moral.

Conforme a Equação [3], todos os coeficientes representativos das dificuldades enfrentadas pelos estudantes em vulnerabilidade socioeconômica em 2015, obtiveram os sinais esperados e, exceto para a influência do assédio moral, todas as outras relações apresentaram-se estatisticamente significativas em nível de 10\%. Dificuldades decorrentes da pior formação no ensino médio, da necessidade de trabalhar e da insuficiência dos programas de assistência estudantil no suprimento das necessidades dos estudantes foram significativos a 1,5 e $10 \%$, respectivamente.

Os resultados encontrados estão de acordo com Santos (2009). Segundo o autor, para uma permanência qualificada na universidade são necessárias condições materiais que permitam a subsistência. É necessário dinheiro para comprar livros, almoçar, lanchar, pagar o transporte etc. Mas é necessário também o apoio pedagógico, a valorização da autoestima, os referenciais docentes etc.

Coulon (2008) também concordou com a amplitude de fatores que podem influenciar o desempenho acadêmico do estudante. $\mathrm{O}$ autor refletiu sobre as diversas rupturas ocorridas na vida do estudante, na passagem do tempo do colégio até a universidade, implicando no distanciamento da família e de amigos e exigindo um esforço de adaptação a um novo mundo e a assimilação de novos códigos e normas.

O coeficiente de determinação ajustado ( $\mathrm{R}^{2}$ aj) do modelo indicou que apenas $5 \%$ da variância do desempenho acadêmico dos estudantes em vulnerabilidade socioeconômica foi explicado. $\mathrm{O}$ baixo valor do $\mathrm{R}^{2}$ alcançado foi esperado, pois o objetivo do modelo é avaliar a influência das dificuldades peculiares do estudante em vulnerabilidade socioeconômica e não maximizar a previsão do desempenho acadêmico (GUJARATI, 2000), porém, esse resultado 
sugere que existem outras variáveis que podem afetar o desempenho acadêmico do estudante além das utilizadas. Na mesma linha de Gujarati (2000), para Goldberger (1991), um $\mathrm{R}^{2}$ alto não é nenhuma evidência em favor do modelo e um baixo $\mathrm{R}^{2}$ não é nenhuma evidência contra ele. $\mathrm{O}$ teste $\mathrm{F}$ atestou que as variáveis explicativas utilizadas, em conjunto, foram estatisticamente significativas em nível de $2 \%$.

O tamanho da amostra alcançou a relação de quase 50 casos para cada variável explicativa, ou seja, bem superior ao mínimo para aplicação da regressão múltipla de 20 casos por variável explicativa sugerida por Hair Jr. et al. (2005).

Em relação à avaliação econométrica, os valores de FIV inferiores a 10 indicaram ausência de multicolineariedade e os testes BPG e estatística $d$ confirmaram a ausência de heteroscedasticidade e autocorrelação em nível de 1\%. Portanto, a partir da avaliação estatística e econométrica do modelo, podemos considerar os resultados da Equação 3 como confiáveis e passíveis de serem interpretados.

Complementando os resultados das análises de regressão, os entrevistados indicaram outras dificuldades enfrentadas pelo aluno em vulnerabilidade socioeconômica que podem afetar o seu rendimento acadêmico. Devido aos comentários serem abertos, muitas respostas apenas corroboraram ou ajudaram a entender os resultados alcançados na análise de regressão. As análises desses comentários permitiram resumir o conteúdo das respostas em sete dimensões, conforme a Figura 16. 
Figura 16. Dificuldades enfrentadas pelos estudantes em vulnerabilidade socioeconômica

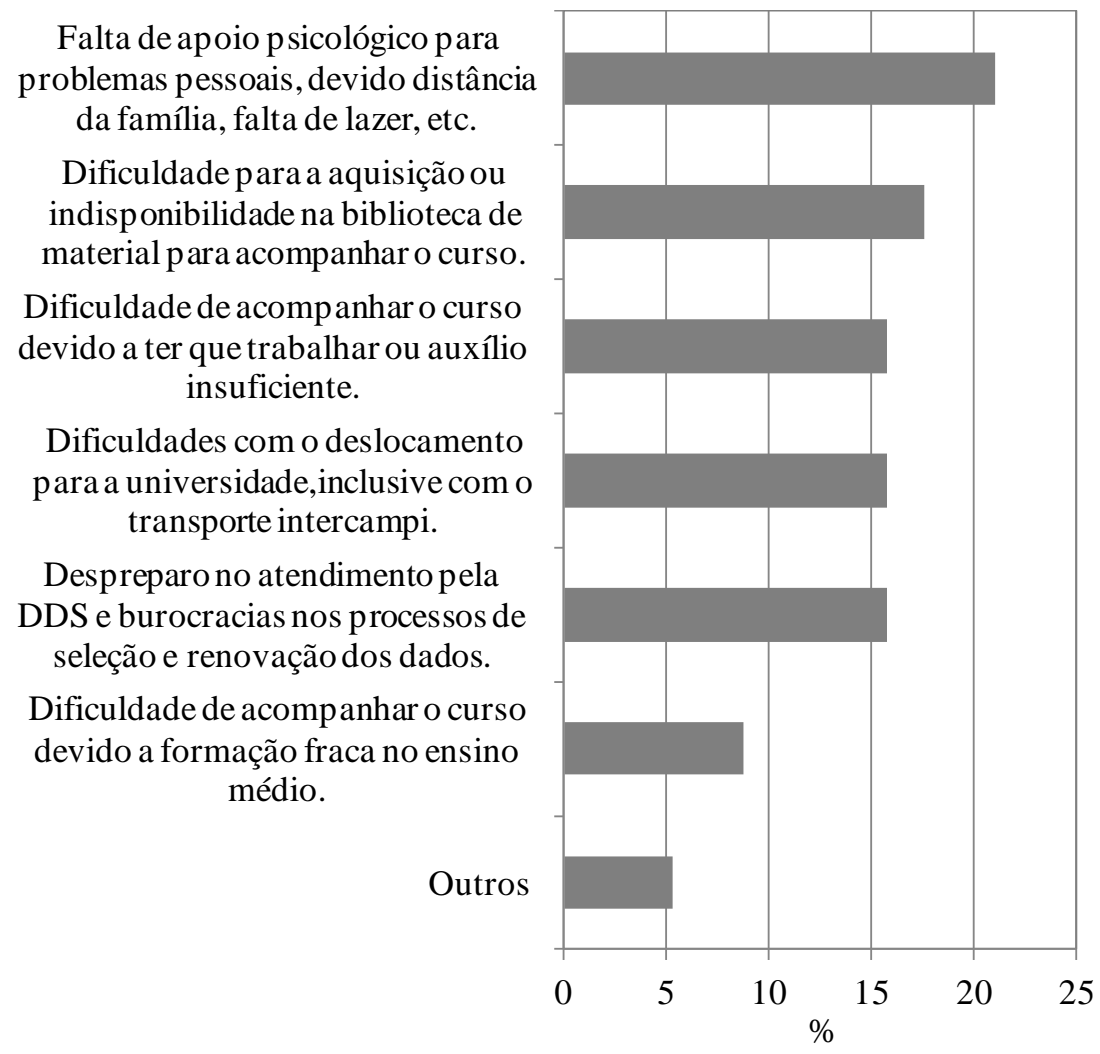

Nota: Número total de comentários referentes às dificuldades sofridas pelos estudantes em vulnerabilidade socioeconômica igual a 57 .

Os resultados da Figura 16 sugerem que a variável apoio psicológico, não contemplada diretamente entre as variáveis do modelo de regressão, poderia ajudar a explicar o baixo rendimento acadêmico do aluno em vulnerabilidade socioeconômica. A importância do apoio psicológico para a eficácia das políticas de assistência estudantil foi corroborada por Costa (2010) e Magalhães (2013), destacando a necessidade de recursos humanos qualificados para o desenvolvimento de ações das mais diversas ordens, tanto no âmbito pedagógico, quanto psicológico.

Além do suporte psicológico, duas outras variáveis importantes, e também desconsideradas no modelo de regressão, podem afetar o rendimento dos estudantes em vulnerabilidade socioeconômica. Essas estiveram relacionadas com a dificuldade de deslocamento para o campus da UnB e com problemas para seleção de alunos com direito a assistência estudantil, conforme relatado no desabafo de um estudante: 
O pior não é ser zuado por um aluno almofadinha rico que mora no Plano Piloto, o pior é ver que alguns professores não dão a mínima para sua situação. Sequer cogitam a possibilidade de ter alguém da turma que não é rico (no meu curso só dá playboy mesmo, nada contra eles, mas poxa, tem raros casos de gente que não nasceu em berço de ouro), daí vem professor cobrar materiais caríssimos para você comprar, sendo que você não tem dinheiro nem para a passagem praticamente. Você está com o mesmo tênis há três semestres no pé. Daí você não recebe o auxílio socioeconômico e ainda presencia um cara com roupas de marca e caras, morador do Guará e que possui carro falar que teve que MENTIR MUITO para conseguir auxílio socioeconômico e você deixa de receber porque foi sincero. É tenso. E sabe por que escrevi tanto? Porque lá não tem ninguém para desabafar. Ninguém liga para você mesmo (Estudante 179).

\section{Outros comentários dos entrevistados representativos dos grupos formados na Figura}

\section{6 foram apresentados no Quadro 12.}

Quadro 12. Alguns comentários em relação às dificuldades do estudante em vulnerabilidade

\section{socioeconômica}

\begin{tabular}{|c|c|}
\hline Dimensão & Críticas ou Sugestões dos Estudantes em Vulnerabilidade Socioeconômica \\
\hline $\begin{array}{l}\text { Falta de apoio psicológico } \\
\text { para problemas pessoais, } \\
\text { devido distância da família, } \\
\quad \text { falta de lazer, etc. }\end{array}$ & $\begin{array}{l}\text { - Questões pessoais como distância da família ou até mesmo problemas com } \\
\text { parentes (Estudante 60). } \\
\text { - Num geral eu e outros amigos carentes do meu convívio temos muitas } \\
\text { dificuldades familiares,o que gera grandes desgastes emocionais durante o } \\
\text { semestre dificultando assim nossa aprendizagem (Estudante } 87 \text { ). }\end{array}$ \\
\hline $\begin{array}{l}\text { Dificuldade para a aquisição } \\
\text { ou indisponibilidade na } \\
\text { biblioteca de material para } \\
\text { acompanhar o curso. }\end{array}$ & $\begin{array}{l}\text { - Falta de acesso a materiais didáticos e atividades de formação complementar a } \\
\text { parte de seus cursos, (como workshops, oficinas, cursos, estágios etc.) em } \\
\text { grande parte não disponibilizados pela universidade (Estudante 15). } \\
\text { - A biblioteca embora seja boa, não tem exemplares de livros suficientes para } \\
\text { suprir a demanda, então uma pequena quantidade de alunos consegue pegar o } \\
\text { livro de uma matéria [...] (Estudante 51). }\end{array}$ \\
\hline $\begin{array}{l}\text { Dificuldade de acompanhar } \\
\text { o curso devido a ter que } \\
\text { trabalhar ou auxílio } \\
\text { insuficiente. }\end{array}$ & $\begin{array}{l}\text { - [...] estudantes carentes tem que trabalhar para ajudar os pais e seu rendimento } \\
\text { cai muito (Estudante 93). } \\
\text { - Os programas não suprem as necessidades de nós alunos, visto que os } \\
\text { professores pedem muitas coisas além do que podemos comprar, como } \\
\text { vestimentas adequadas para aulas práticas, livros, Xerox etc. (Estudante 112). }\end{array}$ \\
\hline $\begin{array}{l}\text { Dificuldades com o } \\
\text { deslocamento para a } \\
\text { universidade,inclusive com } \\
\text { o transporte intercampi. }\end{array}$ & $\begin{array}{l}\text { - Os alunos que dependem do transporte público e moram longe da universidade } \\
\text { sofrem com os horários, principalmente com aqueles professores que não } \\
\text { admitem atrasos (Estudante 42). } \\
\text { - A falta de ônibus que a UnB disponibiliza de um campus para o outro em } \\
\text { alguns horários [...] (Estudante 49). }\end{array}$ \\
\hline $\begin{array}{l}\text { Despreparo no atendimento } \\
\text { pela DDS e burocracias nos } \\
\text { processos de seleção e } \\
\text { renovação dos dados. }\end{array}$ & $\begin{array}{l}\text { - Burocrático e demorado ser contemplado pela assistência estudantil (Aluno } \\
\text { 122). } \\
\text { - Falta de respeito e informação pela DDS e UnB geral (Estudante 137). }\end{array}$ \\
\hline $\begin{array}{l}\text { Dificuldade de acompanhar } \\
\text { o curso devido à formação } \\
\text { fraca no ensino médio. }\end{array}$ & $\begin{array}{l}\text { - As dificuldades ao longo do curso não são assistidas pela Universidade, não } \\
\text { temos professores e monitores para auxiliar (Estudante 94). } \\
\text { - Dificuldades de acompanhar o conteúdo das disciplinas na UnB devido a uma } \\
\text { formação de pior qualidade no ensino médio (escola pública) (Estudante 117). }\end{array}$ \\
\hline Outros & $\begin{array}{l}\text { - O problema das greves dos servidores (praticamente todo ano tem greve), isso } \\
\text { causa problema nos editais da assistência estudantil (Estudante 118). } \\
\text { - Muitos alunos são beneficiados, mas não possuem noção de como administrar } \\
\text { o benefício por conta própria e muitos não possuem os pais ou responsáveis pela } \\
\text { educação para orientá-los por perto (Estudante } 81 \text { ). }\end{array}$ \\
\hline
\end{tabular}




\section{CONCLUSÕES}

Entre os Programas de Assistência Estudantil da UnB, os mais importantes são o Auxílio Socioeconômico, o Auxílio Alimentação e o Programa Moradia Estudantil. O Programa Auxílio Alimentação foi identificado como o de maior qualidade e o Programa Auxilio Socioeconômico como o mais conhecido. Em geral, todos os Programas de Assistência Estudantil da UnB apresentaram alguma deficiência no aspecto conhecimento ou na sua qualidade, podendo ser aprimorados pela DDS/DAC.

Todos os Programas de Assistência Estudantil que oferecem algum recurso financeiro direto receberam sugestões para a atualização do valor, principalmente, o Programa Moradia Estudantil, dado a incompatibilidade do valor recebido com o alto custo de vida em Brasília. Além do baixo valor, também foram constatadas muitas críticas em relação ao atraso nos pagamentos dos benefícios. Uma constatação específica para o Programa Bolsa Permanência foi o seu pouco conhecimento, provavelmente por ser um programa direcionamento para um público específico.

A alta qualidade do Programa Auxílio Alimentação (PAA), conforme percepção dos estudantes em vulnerabilidade socioeconômica se deve a possibilidade de realizar refeições gratuitas no RU. Certamente, a percepção do estudante sobre esse programa ponderou o seu alto benefício relativo, pois a realização de refeições fora do RU, além de ser muito cara, causaria o empecilho de locomoção para fora do campus. Ainda assim, embora bem avaliado, destacaram-se sugestões para pagamento de valor monetário nos casos em que o estudante em vulnerabilidade socioeconômica comprovasse dificuldade de ter acesso ao RU, tornando esse auxílio alternativo ao RU e, portanto, com um valor compatível com o benefício adquirido pelo restaurante.

O Programa Auxílio Emergencial (PAE) se mostrou limitado no atendimento do seu objetivo, os motivos foram a sua pouca divulgação e a burocracia e lentidão na concessão do 
benefício, assim, estando incompatível com o propósito de resolver questões emergenciais que demandam agilidade e regras bem conhecidas. O fato de esse auxílio ser concedido apenas para estudantes desvinculados de outros programas de assistência também foi foco de muitas críticas, o argumento é de que todos os alunos em vulnerabilidade socioeconômica podem passar por situações imprevistas e momentâneas e os outros benefícios não são suficientes e não possuem o caráter emergencial.

O Programa de Acesso à Língua Estrangeira (PALE), na sua essência, não apresentou maiores críticas, tendo a Escola de Idiomas da UnB recebido muitos elogios e a importância do programa ter sido reconhecida pelos estudantes. O grande problema desse programa é o descompasso entre a oferta e a demanda de vagas, limitando o acesso ao benefício.

Entre os programas analisados, o Programa Vale Livro (PVL) foi o menos importante, bem como, apresenta dificuldades em cumprir os seus objetivos. A pouca importância se deve a acessibilidade de material pela internet, digitalizados, cópia xerográfica ou na biblioteca. Já a dificuldade de cumprir o seu objetivo decorre do baixo desconto, apenas $10 \%$ de abatimento no valor do livro, e a sua restrição para livros publicados pela Editora da UnB, a qual não contempla a maioria dos livros utilizados nos cursos.

A avaliação dos RUs da UnB foi positiva, exceto pela qualidade do suco e variedade do cardápio, em geral, as outras variáveis analisadas foram caracterizadas com uma qualidade boa, muito boa ou excelente. Embora algumas críticas pontuais tenham sido registradas quanto à higiene da comida e ao horário de funcionamento do RU, em geral, esses aspectos foram bem classificados para a maioria dos alunos carentes. Os principais aspectos para serem melhorados dizem respeito a pouca variedade do cardápio e a baixa qualidade do suco.

Alguns problemas específicos ocorrem apenas no RU do campus Darcy Ribeiro como, por exemplo, a baixa agilidade no atendimento e longas filas. Outros problemas ocorrem 
apenas nos RUs dos campi de Ceilândia, Gama e Planaltina, destacando falhas na infraestrutura desses restaurantes na proteção contra intempéries.

As principais críticas da Casa do Estudante Universitário (CEU) estiveram relacionadas com problemas de falta de água e, principalmente, com a falta de internet. Problemas arquitetônicos de falta de ventilação nos banheiros gerando mofo nas paredes, bem como, falta de portas nos quartos e, consequentemente, perda de privacidade dos moradores se destacaram. Além desses, a falta de suporte de servidores para realização de pequenos reparos como, por exemplo, de chuveiros queimados, deixou a desejar.

A maioria dos estudantes que respondeu o questionário da pesquisa declarou que a assistência estudantil da UnB não é suficiente para atender as suas necessidades como estudantes; e apenas uma minoria de estudantes revelou trabalhar ou exercer alguma atividade remunerada fora do expediente do curso. Apenas uma minoria dos entrevistados afirmou que os estudantes em vulnerabilidade socioeconômica passam por problemas de assédio moral acima do normal, sugerindo que esse não seja um problema recorrente na UnB, entretanto, criticaram a qualidade do apoio psicológico oferecido, refletindo sobre dificuldades emocionais em relação à distância da família, falta de lazer, entre outras.

Em relação ao desempenho no curso, os resultados não sugeriram uma pior performance dos estudantes em vulnerabilidade socioeconômica. Porém, encontrou relação direta entre dificuldades decorrentes da pior formação no ensino médio, da perda de foco devido à necessidade de trabalhar e da falta de tranquilidade resultante da insuficiência dos programas de assistência estudantil com o pior desempenho acadêmico no curso pelos alunos carentes.

As informações analisadas nesta dissertação têm por essência corroborar com os estudos sobre a Assistência Estudantil no âmbito do Programa Nacional de Assistência Estudantil/PNAES, bem como, contribuir para a construção de políticas que possam mitigar 
os efeitos negativos que a vulnerabilidade socioeconômica traz ao processo de desenvolvimento social no ensino superior. A produção dessas informações pode contribuir na reflexão da dinâmica do desenho de políticas sociais mais equilibradas e harmônicas na Universidade de Brasília. 


\section{REFERÊNCIAS}

ALMEIDA, N. L. T. Educação pública e serviço social. Serviço Social e Sociedade, São Paulo, no 63, 2010.

ALVES, J. M. A assistência estudantil no âmbito da política de educação superior pública. Serviço Social em Revista, v.5, n.1, p.1-9, 2009.

ALVES, J. Estudante diz ter encontrado larva no almoço do RU da UFPB. Disponível em: $<$ http://g1.globo.com/pb/paraiba/noticia/2013/07/estudante-diz-ter-encontrado-larva-no-almoco-do-ru-daufpb.html>. Acesso: 02 janeiro 2016.

ANDIFES. Perfil socioeconômico e cultural dos estudantes de graduação das universidades federais brasileiras. Brasília, junho de 2011. TC Gráfica e Editora.

ARAUJO, D. F.; ALMONDES, K. M. Avaliação da sonolência em estudantes universitários de turnos distintos. Psico-USF, v.17, n.2, p. 295-302, 2012.

BARROS, A. S. X. A Expansão do Ensino Superior no Brasil. Educ. Soc., Campinas, SP, 2015.

BOURDIEU, P. A escola conservadora: as desigualdades frente à escola e à cultura. In:CATANI, A. e NOGUEIRA, A, M. A. (orgs). Pierre Bourdieu: Escritos de Educação, Petrópolis, RJ, Vozes, 2003a, p.39-64.

BRASIL. Decreto $\mathrm{n}^{\circ}$ 7234, de 19 de julho de 2010. Dispõe sobre o Programa Nacional de Assistência Estudantil. Poder Executivo. Brasília, DF, 20 de julho de 2010.

Decreto $n^{\circ}$ 6096, de 24 de abril de 2007. Institui o Programa de Apoio a Planos de Reestruturação e Expansão das Universidades Federais - REUNI. Diário Oficial da União. Poder Executivo. Brasília. DF, 24 de abril de 2007.

Constituição (1988). In: OLIVEIRA, Juarez de (Org.). Constituição da República

Federativa do Brasil. Promulgada em 5 de outubro de 1988. 4. ed. São Paulo: Saraiva, 1990.

BREUSCH, T.; PAGAN, A. A simple test for heteroscedasticity and random coefficient variation. Econometrica, v. 47, p. 1287- 1294, 1979.

BRITO, P.; BRITO, L. A. L. Vantagem competitiva, criação de valor e seus efeitos sobre o desempenho. RAE, São Paulo, v. 52, n. 1, jan./fev. 2013.

BUARQUE, C. Universidade emancipadora com olho no futuro. In: SOUSA JR, J. G. de; BUARQUE, C. (Org.). Da universidade necessária à universidade emancipatória. Brasília: UnB, 2012. p. 81-88.

CAD/UnB. Resolução do Conselho de Administração no 0012/2014. Cria e regulamenta ad referendum o Programa Auxílio Socioeconômico da UnB (PASeUnB), de 31 de março de 2014. Brasília, legislação da Universidade de Brasília. 
CAD/UnB. Resolução 0109/2013, dispõe sobre o Auxílio Emergencial. Brasília, legislação da Universidade de Brasília.

CANCIAN, A. S. Perfil e Empregabilidade dos Egressos dos Campi Agropecuários de colorado do Oeste e Ariquemes do Instituto Federal de Educação, Ciência e Tecnologia de Rondônia. 2016, 71 f. Dissertação (Mestrado Profissional em Gestão Pública) - Programa de Pós-Graduação Gestão Pública. Universidade de Brasília.

CISlAGHI, J. F.; SILVA, M. T. da. Plano Nacional de Assistência Estudantil e a expansão de vagas nas universidades federais: abrindo o debate. $V$ Encontro brasileiro de educação e marxismo. Marxismo, educação e emancipação humana. Florianópolis, SC, 2011.

COSTA, S. G. A equidade na Educação Superior: uma análise das Políticas de Assistência Estudantil. Dissertação (Mestre em Sociologia). Programa de Pós-Graduação em Sociologia do Instituto de Filosofia e Ciências Humanas da Universidade Federal do Rio Grande do Sul. Rio Grande do Sul - RS: 2010.

COULON, A. A condição de estudante: A entrada na vida universitária. Tradução de Georgina Gonçalves dos Santos e Sônia Maria Rocha Sampaio. Salvador, EDUFBA, 2008.

DALlANONA, C. A; SCHIELFER M.F. O. Desempenho Acadêmico de Estudantes Oriundos de Escolas Públicas: curso de graduação do Campus Curitiba da UFPA. Anais XXXIX Congresso Brasileiro de Ensino de Engenharia (COBENGE). Blumenau/SC, 2011.

DCE/UFRR. Estudante diz ter encontrado larvas em comida de restaurante da UFRR. Disponível em: <http://g1.globo.com/rr/roraima/noticia/2016/01/estudante-diz-ter-encontrado-larvas-em-comida-derestaurante-da-ufrr.html>. Acesso: 02 janeiro 2016.

DDS. Relatório de Gestão da Diretoria de Desenvolvimento Social. Decanato de Assuntos Comunitários - DAC. Brasília, 2015.

FÓRUM NACIONAL DE PRÓ-REITORES DE ASSUNTOS COMUNITÁRIOS E ESTUDANTIS - FONAPRACE. Perfil Socioeconômico e Cultural dos Estudantes de Graduação das Universidades Federais Brasileiras. Fórum Nacional de Pró-Reitores de Assuntos Comunitários e Estudantis (FONAPRACE). Brasília: FONAPRACE, 2011.

FUB. Relatório de Gestão, Brasília, 2008.

GERMANO, M. I. S. Treinamento de manipuladores de alimentos: fator de segurança alimentar e promoção da saúde. Livraria Varela/ Higiene Alimentar. São Paulo. 2003.

GISI, M. L. A Educação Superior no Brasil e o caráter de desigualdade do acesso e da permanência. Diálogo Educacional, v. 6, n. 17, p. 97-112, 2006.

GOLDBERGER, A. S. A Course in Econometrics. Massachusetts: [s.n.], 1991.

GUJARATI, D. N. Econometria Básica. 4. ed., São Paulo: Makron Books; 2000. 
HAIR, Jr. J. F.; ANDERSON, R. E.; TATHAM, R. L.; BLACK, W. C. Análise multivariada de dados. 5. ed., Porto Alegre: Bookman; 2005.

HUTCHInSON, B. Mobilidade e Trabalho: Um Estudo na Cidade de São Paulo. Rio de Janeiro: Centro Brasileiro de Pesquisas Educacionais - INEP e Ministério da Educação e Cultura, 1960.

IOSCHPE, G. A Ignorância Custa um Mundo: O Valor da Educação no Desenvolvimento do Brasil. São Paulo: Francis, 2004.

KAZTMAN, R. Seducidos y abandonados: el aislamiento social de los pobres urbanos. Revista de la CEPAL, n. 75, p.171-189, 2001

LABAREE, David L. Public Goods: The American Struggle over Education Goals. American Education Research Journal, vol. 34, nº 1, 39-81. Spring, 1997. Disponível em: <http://links.jstor.org/sici?sici=00028312\%28199721\%2934\%3A1\%3C39\%3APGPGTA\%3E 2.0.CO\%3B2>. Acesso em: 15 janeiro 2016.

LAHIRE, B. O homem plural: os determinantes da ação. Petrópolis: Vozes, 2002.

LEAL LOBO S. F. R.; MONTEJUNAS P. R.; HIPÓLITO O.; LOBO. M. B. C. M. A Evasão no Ensino Superior Brasileiro. Instituto Lobo para o Desenvolvimento da Educação, da Ciência e da Tecnologia, Dezembro 2007.

LIMA, K. R. de S. Contra-reforma na educação superior: de FHC a Lula - São Paulo: Xamã, 2007.

MANCEBO, D. Reforma universitária: reflexões sobre a privatização e a mercantilização do conhecimento. Educ. \& Soc., v. 25, n. 88, 2004.

MAGAlHÃES, R. P. Assistência Estudantil e o seu papel na Permanência dos Estudantes de Graduação: A Experiência da Universidade Federal do Rio de Janeiro. Dissertação (Mestrado em Serviço Social). Programa de Pós-Graduação em Serviço Social da PUC-Rio. Rio de Janeiro/RJ: 2013.

MARTINS, C. B. Uma Reforma Necessária. Campinas: vol. 27, n. 96 - Especial, p. 1001 1020, out. 2006. Disponível em: 〈http://www.cedes.unicamp.br〉. Acesso em 03 dezembro 2015.

MEC. Ministério da Educação/2013. Disponível em: <http://permanencia.mec.gov.br/>. Acesso em: 06 junho 2016.

Ministério da Educação. Portaria Normativa no 39, de 12 de dezembro de 2007. Institui o Programa Nacional de Assistência Estudantil - PNAES. Brasília, 2007. Disponível em: <http://permanencia.mec.gov.br/>. Acesso em: 20 novembro 2015.

Portaria $\mathrm{n}^{\mathbf{0}}$ 389, de 9 de maio de 2013. Cria o Programa de Bolsa Permanência e dá outras providências. Disponível em: <http://permanencia.mec.gov.br/>. Acesso em: 06 outubro 2014. 
MORALES, R. M. C., FLORES, M. V., MENESES, A. C., FIGUEIRAS, S. C., GUERREIRO, J. M. Sleepiness, performance and mood state in a group of Mexican undergraduate students. Biological Rhythm Research, v.36, n. 1/2, p. 9-13, 2005.

NAZARETH, H. Ciências Exatas, Editora Ática. São Paulo, 1999.

NERES, I. V. Comparação do perfil e da situação entre o aluno evadido e o egresso da Faculdade Unb de Planaltina - FUP. 2015. 92 f. Dissertação (Mestrado Profissional em Gestão Pública) - Programa de Pós-Graduação Gestão Pública. Universidade de Brasília.

NEVES, J. Características, Usos e Possibilidades. Caderno de pesquisas em administração, São Paulo, 2015.

PAIVA, D.S.; MENDES, G.R. "Onde se pode ficar nu"- Territorialidade e privacidade na casa do Estudante Universitário da UnB. Série: Textos de Alunos de Psicologia Ambiental, 7, Brasília, UnB, Laboratório de Psicologia Ambiental, 2001.

PESTANA, M. H.; GAGEIRO, J. N. Análise de dados para Ciências Sociais. $4^{\circ}$ Edição. Edições Sílabo, Lisboa, 2005.

REZENDE, F. Planejamento no Brasil: auge, declínio e caminhos para a reconstrução. In: CARDOSO JR., José Celso (Org.). A reinvenção do planejamento governamental no Brasil. Brasília: IPEA, 2011. v.4. 517 p.

SANTOS, D. B. R. Para além das cotas: a permanência de estudantes negros no ensino superior como política de ação afirmativa. Salvador. 2009. 214f. Tese (Doutorado em Educação) - Universidade Federal da Bahia, Salvador. Disponível em: . Acesso em: 16 novembro 2014.

SECOM/UnB. UnB inaugura mesa de negociação com 2010. Disponível em: <www.unb.br/noticias/unbagencia/unbagencia.php?id=2841>. Acesso em: 06 de abril de 2016.

SECOM/UnB. Discussão sobre Desocupação da CEU. Disponível em: <www.unb.br/noticias/unbagencia/unbagencia.php?id=5201 >. Acesso em: 06 de abril de 2016

SECOM/UnB. Casa do Estudante Universitário é inaugurada, 2014. Disponível em: $<$ http://www.unb.br/noticias/unbagencia/unbagencia.php?id=9156>. Acesso em: 06 abril 2016.

SGUISSARDI, V. Reforma universitária no Brasil - 1995-2006: precária trajetória e incerto futuro. Educ. \& Soc., v. 27, n. 96 - Especial, p. 1021-1056, 2006.

SILVA FILHO, R. L. L.; MOTEJUNAS, P. R.; HIPÓlitO, O.; LOBO, M. B. C. M. A Evasão no Ensino Superior Brasileiro. Caderno de Pesquisa, São Paulo, v. 37, n. 132, dez. 2007. Disponível em: <http://www.scielo.br/scielo.php>. Acesso em 13 julho 2015.

SILVA, J. C. Pesquisa qualitativa rev. [online]. 2008. 
UFMG. Assistência estudantil. Belo Horizonte 2016. Disponível em: <http://www.fump.ufmg.br/conteudo.aspx?pagina〉. Acesso em 05 junho 2016.

UFPR. Assistência Estudantil. Paraná/2016. Disponível em: <http://www.prae.ufpr.br/prae/noticias>. Acesso em: 05 junho 2016.

UFRJ. Assistência Estudantil. Rio de Janeiro/2016. Disponível em: 〈http://superest.ufrj.br〉. Acesso: 05 junho 2016.

UnB. Relatório de Gestão do Exercício. Brasília, 2014

VARGAS, H. M. Sem Perder a Majestade: "Profissões Imperiais" no Brasil. Estudos de Sociologia. Araraquara, v.15, n.28, p. 107-124. Niterói: Centro de Estudos Sociais Aplicados da Universidade Federal Fluminense, 2010.

VASCONCELlOS, L. Economia do Setor Público no Brasil. Rio de Janeiro: Elsevier, 2004.

VILELA, A. J. Uma Visão sobre Alojamentos Universitários no Brasil. In DOCOMOMO Brasil, 5, São Carlos, 2003. Anais... São Carlos: USP, 2003.

ZANCUL, J. S.; FABRÍCIO, M. M. Estudar e habitar em São Carlos: avaliação pós-ocupação da habitação estudantil no entorno do campus da USP, São Carlos. Revista de Pesquisa em Arquitetura e Urbanismo, n.7, p. 123-146, 2008.

ZAGO, N. Do acesso à permanência no ensino superior: percursos de estudantes universitários de camadas populares. Revista Brasileira de Educação, v. 11, n. 32, 2006. 
ANEXO 1. Questionário aplicado

\section{AVALIAÇÃO PROGRAMA AUXÍLIO SOCIOECONÔMICO}

- Essa pesquisa tem como objetivo gerar informações para a melhoria dos programas de auxílio estudantil da UnB. Tempo médio de resposta é de 15 minutos.

- Respondentes não precisam se identificar.

- Caso não queira ou não saiba responder quaisquer perguntas, por favor, deixe-as em branco.

INFORMACÕES DOS PROGRAMAS DE ASSISTÊNCIA ESTUDANTIL DA UnB

1) Indique o seu grau de conhecimento e atribua o grau de importância (na sua opinião) dos programas abaixo. O objetivo dessas perguntas é gerar subsídios para possíveis ampliações ou modificações nos programas, bem como, melhorias da sua divulgação aos estudantes.

PROGRAMA DE AUXílio SOCIOECONÔMICO (auxílio de R\$ 465,00 para os estudantes em situação de vulnerabilidade socioeconômica).

\section{Grau de Conhecimento}

Desconheço Completamente 10 \begin{tabular}{l|l|l|l|l|l|l|l|l|l|l} 
& 2 & 3 & 4 & 5 & Conheço Completamente
\end{tabular}

Grau de Importância

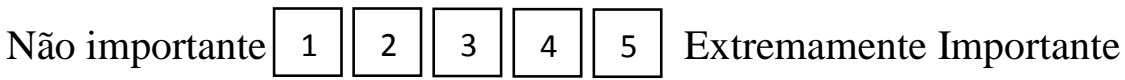

AUXÍlIO ALIMENTAÇÃO COMPLEMENTAR PARA ESTUDANTES DO PROGRAMA MORADIA (auxílio alimentação complementar para os dias em que o Restaurante Universitário/RU não estiver em funcionamento no valor de R \$ 15,00).

Grau de Conhecimento

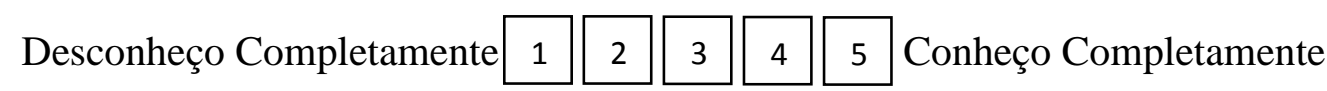

Grau de Importância

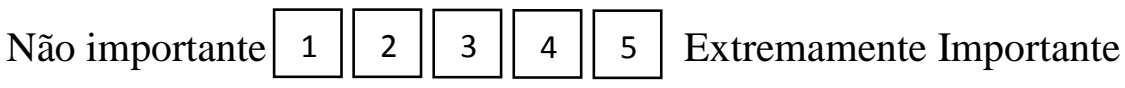

PROGRAMA MORADIA ESTUDANTIL (moradia temporária na Casa do Estudante (CEU) ou auxílio mensal de $\mathrm{R} \$ 530,00$, tendo prioridade estudantes em vulnerabilidade socioeconômica cujas famílias residam fora do DF).

\section{Grau de Conhecimento}

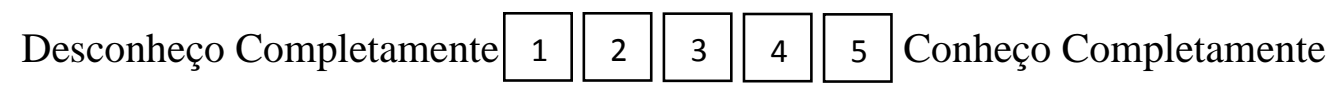

Grau de Importância

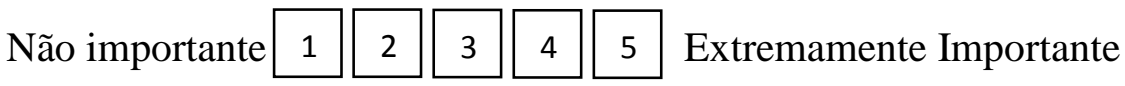


PROGRAMA DE ACESSO À LÍNGUA ESTRANGEIRA (isenção no pagamento de mensalidades nos cursos da Escola UnB de idiomas).

\section{Grau de Conhecimento}

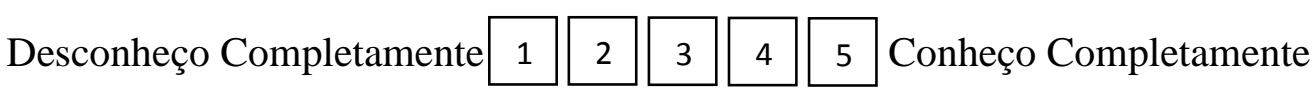

\section{Grau de Importância}

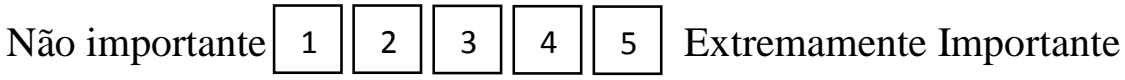

BOLSA PERMANÊNCIA DO MEC (auxílio de R $\$$ 400,00 para outros estudantes participantes da Bolsa Permanência e R \$ 900,00 para indígena ou quilombola).

\section{Grau de Conhecimento}

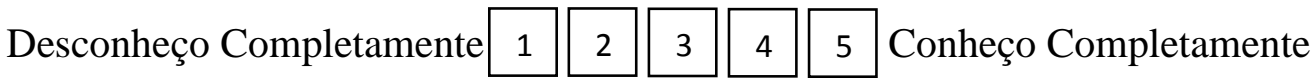

\section{Grau de Importância}

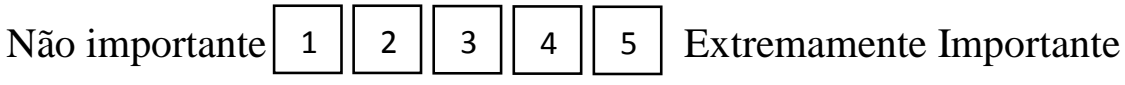

PROGRAMA AUXÍLIO EMERGENCIAL (auxílio para estudantes que não estejam inseridos em outros programas de assistência estudantil para casos de vulnerabilidade econômica inesperada).

\section{Grau de Conhecimento}

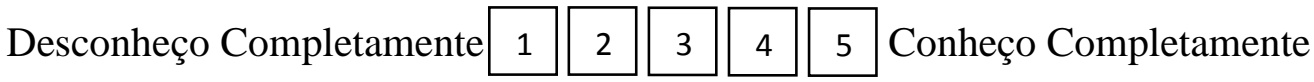

\section{Grau de Importância}

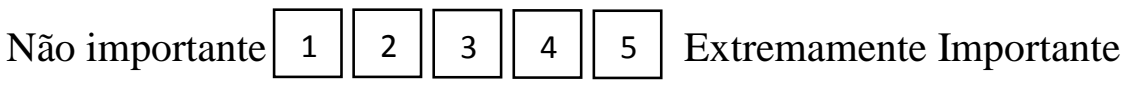

VALE LIVRO (cinco vales por semestre que dão direito a 10\% de desconto, além dos $40 \%$ de desconto para estudantes da UnB, na compra de livros editados pela Editora UnB).

\section{Grau de Conhecimento}

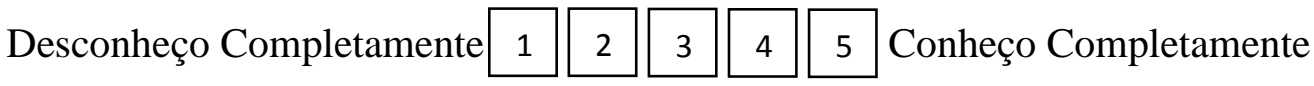

\section{Grau de Importância}

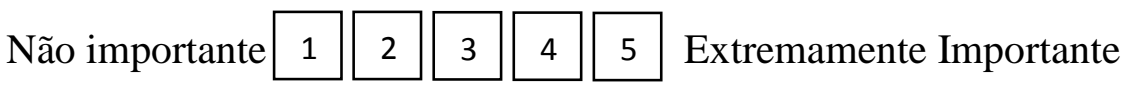


2) Na sua opinião qual é o grau de qualidade dos programas abaixo. Leve em conta todos os aspectos que podem afetar a qualidade do programa como, por exemplo: dificuldade de acesso, auxílio insuficiente, atrasos constantes, burocracias, entre outros.

PROGRAMA DE AUXÍlLIO SOCIOECONÔMICO (auxílio de R\$ 465,00 para os estudantes em situação de vulnerabilidade socioeconômica).

Grau de Qualidade

\begin{tabular}{l|l|l|l|l|l|l|l|l}
\hline Ruim & 1 & 2 & 3 & 4 & 5 & Excelente
\end{tabular}

Por favor, deixe suas críticas e/ou sugestões para melhoria do programa.

AUXÍlIO ALIMENTAÇÃO COMPLEMENTAR PARA ESTUDANTES DO PROGRAMA MORADIA (auxílio alimentação complementar para os dias em que o Restaurante Universitário/RU não estiver em funcionamento no valor de R\$ 15,00).

Grau de Qualidade

\begin{tabular}{l|l|l|l|l|l|l|l|l}
\hline Ruim & 1 & 2 & 3 & 4 & 5 & Excelente
\end{tabular}

Por favor, deixe suas críticas e/ou sugestões para melhoria do programa.

PROGRAMA MORADIA ESTUDANTIL (moradia temporária na Casa do Estudante (CEU) ou auxílio mensal de $\mathrm{R} \$ 530,00$, tendo prioridade estudantes carentes cujas famílias residam fora do DF).

Grau de Qualidade

\begin{tabular}{l|l|l|l|l|l|l|l|} 
Ruim & 1 & 2 & 3 & 4 & 5 & Excelente
\end{tabular}

Por favor, deixe suas críticas e/ou sugestões para melhoria do programa.

PROGRAMA DE ACESSO À LÍNGUA ESTRANGEIRA (isenção no pagamento de mensalidades nos cursos da Escola UnB de idiomas).

Grau de Qualidade

\begin{tabular}{l|l|l|l|l|l|l|l|l|} 
Ruim & 1 & 2 & 3 & 4 & 5 & Excelente
\end{tabular}

Por favor, deixe suas críticas e/ou sugestões para melhoria do programa. 
BOLSA PERMANÊNCIA DO MEC (auxílio de R \$ 400,00 para outros estudantes e R\$ 900,00 para indígenas ou quilombolas).

\section{Grau de Qualidade}

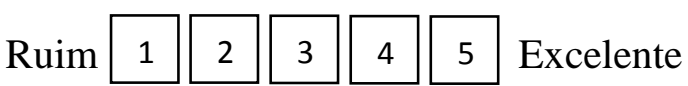

Por favor, deixe suas críticas e/ou sugestões para melhoria do programa.

PROGRAMA AUXíLIO EMERGENCIAL (auxílio para estudantes que não estejam inseridos em outros programas de assistência estudantil para casos de vulnerabilidade econômica inesperada).

\section{Grau de Qualidade}

\begin{tabular}{l|l|l|l|l|l|l|l|} 
Ruim & 1 & 2 & 3 & 4 & 5 & Excelente
\end{tabular}

Por favor, deixe suas críticas e/ou sugestões para melhoria do programa.

VALE LIVRO (cinco vales por semestre que dão direito a 10\% de desconto, além dos $40 \%$ de desconto para estudantes da UnB, na compra de livros editados pela Editora UnB).

\section{Grau de Qualidade}

\begin{tabular}{l|l|l|l|l|l|l|l|} 
Ruim & 1 & 2 & 3 & 4 & 5 & Excelente
\end{tabular}

Por favor, deixe suas críticas e/ou sugestões para melhoria do programa.

\section{INFORMAC̄ÕES SOBRE O RESTAURANTE UNIVERSITÁRIO - RU}

3) Indique o grau de qualidade dos seguintes aspectos inerentes ao RU.

Agilidade no atendimento (pouca fila) no RU
( ) Ruim
) Razoável
( ) Boa
( ) Muito Boa
( ) Excelente ( ) Não sei

Limpeza dos pratos, copos e talheres no RU

( ) Ruim ( ) Razoável ( ) Boa ( ) Muito Boa ( ) Excelente ( ) Não sei

\section{Quantidade do alimento servido no RU}

( ) Ruim ( ) Razoável ( ) Boa ( ) Muito Boa ( ) Excelente （） Não sei

Qualidade do alimento servido no RU

( ) Ruim ( ) Razoável ( ) Boa ( ) Muito Boa （）Excelente （） Não sei 
Qualidade do suco servido no RU
( ) Ruim
) Razoável ( ) Boa
( ) Muito Boa
( ) Excelente ( ) Não sei

Variedade no cardápio durante a semana

( ) Ruim ( ) Razoável ( ) Boa ( ) Muito Boa ( ) Excelente ( ) Não sei

Limpeza do refeitório

( ) Ruim ( ) Razoável ( ) Boa ( ) Muito Boa ( ) Excelente ( ) Não sei

Tamanho do refeitório (número de mesas e cadeiras)
( ) Ruim
( ) Razoável
( ) Boa
( ) Muito Boa
( ) Excelente ( ) Não sei

Espaços para higiene das mãos e banheiros no RU
( ) Ruim
( ) Razoável
( ) Boa
( ) Muito Boa
( ) Excelente ( ) Não sei

Horário de funcionamento do RU

( ) Ruim ( ) Razoável ( ) Boa ( ) Muito Boa ( ) Excelente ( ) Não sei

4) Por favor, deixe suas críticas ou sugestões para melhoria do Restaurante Universitário - RU

\section{INFORMAC ÕES DA CASA DO ESTUDANTE UNIVERSITÁRIO - CEU DA UnB}

5) Qual é a sua opinião em relação a infraestrutura da Casa do Estudante - CEU.
( ) Ruim
( ) Razoável
( ) Boa
( ) Muito Boa
( ) Excelente
( ) Não sei

Por favor, exponha os principais problemas de infraestrutura da CEU

6) Qual é a sua opinião em relação a disponibilidade e qualidade de serviços, por exemplo: limpeza, segurança, iluminação, internet, água, luz, telefone, entre outros, na CEU.
( ) Ruim
( ) Razoável
( ) Boa
( ) Muito Boa
( ) Excelente ( ) Não sei

Por favor, exponha os principais problemas de infraestrutura da CEU

7) Qual a sua opinião em relação a convivência com outros estudantes na casa do estudante.
( ) Ruim
( ) Razoável
( ) Boa
( ) Muito Boa
( ) Excelente ( ) Não sei

Por favor, exponha os principais problemas em relação a convivência com outros estudantes na CEU 


\section{INFORMACÕES ACADÊMICAS}

8) Em que campus da UnB você estuda?
( ) Darcy Ribeiro
( ) Faculdade UnB Ceilândia
( ) Faculdade UnB Gama
( ) Faculdade UnB Planaltina

9) Em que curso você está matriculado? (Favor escrever por extenso)

10) Comparado aos seus colegas de curso, o seu desempenho acadêmico nas disciplinas da graduação na UnB está:
( ) Entre os $10 \%$ dos alunos com melhor desempenho
( ) Entre os $20 \%$ dos alunos com melhor desempenho
( ) Entre os $50 \%$ dos alunos com melhor desempenho
( ) Entre os alunos de pior desempenho
( ) Não sabe.

11) Participou ou participa de algum projeto de Iniciação Científica - IC? (Inclusive Programa de Educação Tutorial - PET)

( ) Sim, participo ou já participei como voluntário e também como remunerado

( ) Sim, participo ou já participei como remunerado

( ) Sim, participo ou já participei como voluntário

( ) Nunca participei

12) Participa ou participou de algum projeto de extensão? (Inclusive PIBID e Prodocência)

( ) Sim, participo ou já participei como voluntário e também como remunerado

( ) Sim, participo ou já participei como remunerado

( ) Sim, participo ou já participei como voluntário

( ) Nunca participei.

13) Você participa ou já participou de algum estágio remunerado?

( ) Sim, na área e fora da área do meu curso ( ) Sim, na área do meu curso

( ) Sim, porém fora da área do meu curso ( ) Nunca participei

14) Qual o total dos rendimentos (em reais) recebidos por você pelos programas acadêmicos da UnB (IC, extensão, monitoria, PET, entre outros) no último mês?

15) Qual o total de rendimentos (em reais) recebidos por você por meio de estágios remunerados ou outros trabalhos no último mês?

\section{INFORMACÕES DAS DIFICULDADES ENFRENTADAS PELO ALUNO CARENTE}

16) Você trabalha ou exerce alguma atividade remunerada fora do expediente do curso?
( ) Sim
( ) Não 
17) O estudante beneficiado pelos programas de assistência estudantil sofre assédio moral (comentários e brincadeiras que objetivam denegrir imagem pessoal) acima do normal.

Discordo completamente $1 \quad$\begin{tabular}{|l|l|l|l|l|l|}
\hline & 3 & 4 & 5 & Concordo Completamente
\end{tabular}

18) Os programas de assistência estudantil não são suficientes para suprir as necessidades financeiras dos alunos carentes.

Discordo completamente $1 \quad 2 \quad$\begin{tabular}{|l|l|l|l|l|}
\hline & 4 & 5 & Concordo Completamente
\end{tabular}

19) Os estudantes em vulnerabilidade socioeconômica possuem maiores dificuldades de acompanhar o conteúdo das disciplinas na UnB devido a uma formação de pior qualidade no ensino médio.

Discordo completamente $1 \quad$\begin{tabular}{l|l|l|l|l|l|l|l|l|l|l|l|}
\hline & 2 & 3 & 4 & 5 & Concordo Completamente
\end{tabular}

20) Indique outras dificuldades enfrentadas pelos estudantes em vulnerabilidade socioeconômica não abordadas nas questões acima.

Caso já tenha respondido por e-mail , por favor não envie duas vezes.

\section{MUITO OBRIGADO.}

